Illinois State University

ISU ReD: Research and eData

Theses and Dissertations

$6-5-2015$

\title{
The Perceptions of the Unwanted Horse Population in Illinois 2015
}

Kelsey Annette Schueler

Illinois State University, kschueler15@gmail.com

Follow this and additional works at: https://ir.library.illinoisstate.edu/etd

Part of the Agricultural and Resource Economics Commons, Agricultural Economics Commons, and the Animal Sciences Commons

\section{Recommended Citation}

Schueler, Kelsey Annette, "The Perceptions of the Unwanted Horse Population in Illinois 2015" (2015). Theses and Dissertations. 438.

https://ir.library.illinoisstate.edu/etd/438

This Thesis is brought to you for free and open access by ISU ReD: Research and eData. It has been accepted for inclusion in Theses and Dissertations by an authorized administrator of ISU ReD: Research and eData. For more information, please contact ISUReD@ilstu.edu. 


\title{
THE PERCEPTIONS OF THE UNWANTED HORSE
}

\section{POPULATION IN ILLINOIS 2015}

\author{
Kelsey A. Schueler
}

135 Pages

August 2015

A survey to measure the perceptions of the unwanted horse population in the state of Illinois was developed. Horse owners, non-horse owners, and equine industry stakeholders in Illinois were the focus of the study. Participants were surveyed on their perceptions, awareness, and knowledge of the unwanted horse population in the state. Each survey included questions of current knowledge of legislation, background with equine, current methods to control the unwanted horse population, and methods they believe would benefit the population. A block style survey was developed, emailed to a statewide equine association listserv, and advertised through articles online. Findings show that on average horse owners will spend $\$ 3,343$ annually on equine expenditures. There was a significant difference of the average annual cost of horse owners that keep their horse on their own property and owners that do not keep their horse on their property; $\mathrm{t}(304)=9.83, \mathrm{p}<.000$. Findings show $58 \%$ of horse owners view equine as companion animals as opposed to livestock or working animals. Current methods of managing the unwanted horse population were found to be ineffective (2.15) on a fivepoint Likert-type scale (level of effectiveness $1=$ very ineffective through $5=$ very effective). Using frequencies to determine the mean score, horse owners agreed financial 
hardship (4.68) as the highest rated reason for why horses become unwanted. It was found that reducing the cost of euthanasia, carcass disposal, or rendering (4.07), allowing horse processing facilities to reopen in Illinois (3.83), and creating regional euthanasia centers (3.55), can most effectively manage the unwanted horse population with in the state. The results of this survey may lead to a greater awareness of the unwanted horse population in Illinois. Furthermore, the results may lead to discussion about future legislation within the state on supporting and managing the unwanted horse. 
THE PERCEPTIONS OF THE UNWANTED HORSE

POPULATION IN ILLINOIS 2015

KELSEY A. SCHUELER

A Thesis Submitted in Partial Fulfillment of the Requirements for the Degree of

MASTER OF SCIENCE

Department of Agriculture

ILLINOIS STATE UNIVERSITY

2015 
(C) 2015 Kelsey A. Schueler 
THE PERCEPTIONS OF THE UNWANTED HORSE

POPULATION IN ILLINOIS 2015

KELSEY A. SCHUELER

COMMITTEE MEMBERS:

Aslihan D. Spaulding, Chair

Don Meyer

Justin Rickard 


\section{ACKNOWLEDGMENTS}

I would like to express my gratitude to my committee chair, Dr. Aslihan D. Spaulding, for her continuous support of my thesis and research. Dr. Spaulding helped guide me through the ups and downs of graduate school and the completion of this thesis experience. I could not have asked for a more understanding, patient, and enthusiastic advisor to mentor me. A big and well-deserved thank you goes out to the remainder of my thesis committee, which included Dr. Justin R. Rickard and Mr. Don Meyer. They were always just an email, phone call, or a few steps away to help me with any questions. I thank you all for your kind words of encouragement and inspiring me to stretch beyond my comfort level and grow during this process. I would also like to thank the entire Department of Agriculture at Illinois State University faculty, staff, and fellow students for providing me with support and a positive learning environment.

To my amazing office mates and best friends, Katelynn Clement and Cori Harrison-Malone, I owe them both a very big thank you. None of this would be possible without their support and encouragement. They were always there when I needed to vent my frustration, needed a laugh, or a $\$ 2$ burger at Brewe-Ha's to help get through the long process of this master's experience.

Finally, and most importantly I would like to thank my family. My parents, Dan and Cindy Schueler, thank you for always having faith in me, pushing me to be successful, and reminding me to never give up on my dreams. Thank you to my sister 
Darcy Schueler, for your sisterly love and the hours we spent on the phone, encouraging me through this process I must acknowledge my good friend, Scott Galland, who provided his encouragement, support, and editing assistance, I would have not have finished this thesis without you.

Lastly, to the long days and nights listening to my favorite country music,

"The sun shines on a dreamer,

Shines a light on you when you listen to your heart." - Wade Bowen

K.A.S. 


\section{CONTENTS}

ACKNOWLEDGMENTS

CONTENTS

TABLES vi

CHAPTER

I. GENERAL INTRODUCTION 1

Thesis Organization 3

II. REVIEW OF THE LITERATURE 4

Unwanted Horses in the United States 4

Reasons for Why Horses become Unwanted 5

Overall Contributing Factors to the Unwanted Horse Population 7

Current Methods to Maintain the Unwanted Horse Population 13

Unwanted Horse Population in Illinois 17

$\begin{array}{ll}\text { References } & 21\end{array}$

III. THE PERCEPTIONS OF THE UNWANTED HORSE POPULATION IN ILLINOIS 2015

$\begin{array}{ll}\text { Abstract } & 26\end{array}$

$\begin{array}{ll}\text { Introduction } & 27\end{array}$

Materials and Methods 28

Study Design $\quad 29$

Threats to Validity 30

Survey: Illinois Horse Owners, Non-Horse Owners, and
Equine Industry Stakeholders

Participant Recruitment 31 
Survey Dissemination $\quad 34$

Statistical Analysis $\quad 34$

$\begin{array}{ll}\text { Results } & 35\end{array}$

Participant Group 1: Illinois Horse Owners 35

Demographics 35

Horse Ownership $\quad 35$

Euthanasia $\quad 37$

Sold $\quad 38$

Relinquished or Donated 38

Perceptions of Equine and Unwanted Horses in Illinois 39

Primary Responsibility 40

Information on Unwanted Horses 40

Major Reasons for Why Horses Become Unwanted 40

Overall Contributing Factors to the Unwanted Horse Population 41

Perceptions of the Current Methods 41

Perceptions of Effective Methods 42

Suggestions $\quad 42$

Limitations to the Study $\quad 42$

Discussion $\quad 43$

Literature Cited $\quad 46$

IV. CONCLUSIONS TO THE THESIS EXPERIENCE 47

APPENDIX A: Survey Questionnaire for Horse Owners, Non-Horse Owners, and Equine Industry Stakeholders in Illinois 68

APPENDIX B: Article Published in Illinois Farm Bureau's FarmWeek and FarmWeeknow.com $\quad 91$

APPENDIX C: Article for Brownfield Ag News for America 92

APPENDIX D: Non-Horse Owner Non-Reportable Data 93

APPENDIX E: Equine Industry Stakeholder Non-Reportable Data 100 
APPENDIX F: Horse Owner Qualitative Responses Stating Purpose of Their Horses

APPENDIX G: Horse Owner Qualitative Responses Stating Other Reasons for Selling Their Horse

APPENDIX H: Horse Owner Qualitative Responses Stating Other Reasons for Relinquishing or Donating a Horse.

APPENDIX I: Horse Owner Qualitative Responses Stating Organization Name Where They Relinquished or Donated Their Horse

APPENDIX J: Horse Owner Qualitative Responses Stating Other Responses of Current Methods to Control The Unwanted Horse Population in Illinois

APPENDIX K: Horse Owner Qualitative Responses Stating Other Responses to Who Has the Primary Responsibility to Managing the Unwanted Horse Population

APPENDIX L: Horse Owner Qualitative Responses Stating Where They Are Receiving Their Current Information on Unwanted Horses.

APPENDIX M: Horse Owner Qualitative Responses Stating Suggestions They Have for Managing the Unwanted Horse Population

APPENDIX N: Definition of Terms 


\section{TABLES}

Table

1. Perceptions of the Unwanted Horse Population Survey Respondents 2015

2. Household Incomes of Survey Horse Owner Respondents 2015

3. Horse Owner Survey Respondent Education Levels 2015

4. Horse Owner Respondent Zip Code Regions 2015

5. Total Number of Horses, Equine, and Breeds Owned by Horse Owner Respondents

6. Horse Owner Responses' Listing the Main Purpose of Owning Their Horse

7. Independent Sample T-Test Horse Owner Responsibilities

8. Independent Sample T-Test of Annual Expenditures of Horse Owners in the Chicago Area and Other Regions in the State

9. Independent Samples T-test of Total Equine Owned and Where They are Kept

10. Chi-Square Test of the Chicago Region to Other Regions in the State and Where They Board Their Horse

11. Horse Owner Responses for the Most Recent Year of Euthanizing a Horse

12. Horse Owner Responses for the Total Cost to Euthanize Their Horse

13. Horse Owner's Knowledge of the Average Cost to Euthanize and Dispose of a Horse in Illinois 
14. Horse Owner Survey Likert-Scale ${ }^{z}$ Type Questions on Their Belief of the Major Reasons for Why Horses Become Unwanted in Illinois

15. Horse Owner Survey Likert-Scale ${ }^{\mathrm{z}}$ Type Questions on Their Belief of the Overall Contributing Factors to the Unwanted Horse Population 65

16. Horse Owner's Knowledge of Current Methods ${ }^{y}$ to Control the Population in Illinois

17. Horse Owner Survey Likert-Scale ${ }^{\mathrm{z}}$ Type Questions of how Effective the Following Methods Can Be to Manage the Unwanted Horse Population 


\section{CHAPTER I}

\section{GENERAL INTRODUCTION}

Illinois is home to more than 178,463 horses, mules, and donkeys. There are nearly 64,000 equine owners in Illinois and more than 200,000 residents are involved in the equine industry as owners, service providers, employees, volunteers, and even more participate as spectators in equestrian events (Horsemen's Council of Illinois, 2012). However, even though many individuals' love and care for horses, there are still horses becoming unwanted. Unwanted horses are defined by the American Horse Council as those whose current owners no longer want them because they are, "old, injured, sick or unmanageable, or fail to meet the owner's expectations" (American Horse Council, 2009) (Appendix N). Horses also become unwanted due to owners' financial inability to provide care for that animal, a need to decrease herd size, or a loss of interest in horse care and associated activities (Unwanted Horse Coalition, 2009). While there are differing opinions and wide speculation regarding the unwanted horse population in other states and across the nation, there is little research on the awareness of the unwanted horse population in Illinois.

The equine landscape in Illinois displays variation and is diverse. In some areas, breeds and disciplines are localized, while others can be found throughout the state. The equine population has a large economic impact, including equine operations, horse races, horse shows, and trail rides. Within the state of Illinois, the Unwanted Horse Coalition 
has documented seventeen-horse rescue, sanctuary, and adoption agencies (UHC, 2015). Illinois was also home to the last remaining domestic horse-processing plant, Cavel International, Inc. in DeKalb, Illinois, which operated for over twenty years. During the time Cavel was operating they averaged processing one thousand head of horses per week (Cavel Int. v. Madigan, 500 F.3d 558 (7th Cir. 2007). In June 2007, the Illinois Horse Meat Act was upheld in the Seventh Circuit court, which ultimately led to shutting down the processing plant. The Illinois Horse Meat Act "prohibits the slaughter of horses for human consumption as well as importing, exporting, selling, giving, or even possessing horsemeat if a person knows or should know that it will be used for human consumption” (Illinois General Assembly (225 ILCS 635/) Illinois Horse Meat Act). Although the number is difficult to document, the Unwanted Horse Coalition (UHC) estimates that each year there are approximately 130,000-170,000 "unwanted" horses in the United States (House, 2009; UHC, 2009). With no concrete data on the exact number of unwanted horses in the United States, horse industry experts, horse owners, and the media speculate the number of unwanted horses is increasing. Some believe the problem is growing larger due to the poor economy, rising costs of feed, the costs of euthanasia and disposal, capacity rescue populations, and laws banning horse processing.

Many states have commissioned studies to find answers to the growing problem. However, no studies have been completed to assess the unwanted horse population or individual's awareness and perceptions of the problem in the state of Illinois. This study's scope assessed the perceptions, awareness, and knowledge of the unwanted horse population in Illinois because it was the last state to have a domestic horse processing 
plant. The closure of this plant brought along many differing opinions of what will happen to the horse population.

Specifically, this research assessed the knowledge and awareness levels of horse owners, non-horse owners, and equine industry stakeholders in the state. Horse owners and equine industry stakeholders were surveyed to determine the current knowledge of equine legislation, average costs associated with horse ownership, and their perceptions of the current methods to maintain the unwanted horse population. Non-horse owners were surveyed to determine their current awareness of the unwanted horse population, equine legislation, and the current methods to maintain the unwanted horse population within Illinois.

\section{Thesis Organization}

This thesis is organized in an alternate format. It contains a general introduction, a literature review, and a manuscript organized according to the style of the American Society of Animal Science (ASAS). 


\section{CHAPTER II}

\section{REVIEW OF THE LITERATURE Unwanted Horses in the United States}

Horses have long been a part of American history and culture. America's love for horses goes back to the idea of the Wild West, where horses were an iconic figure and trusty steeds. However, the role of horses in society has drastically transitioned throughout the history of the United States. Over the centuries, people of diverse cultural and ethnic backgrounds have settled in the U.S. and have utilized horses for agriculture, commerce, and pleasure. Horses once provided heavy draft power for agricultural fields and transportation and played an essential role during the wars in the United States. More recently, horses have been regarded for their competitive performance and entertainment in racing, showing, and rodeo events. Today, horses often serve as companion animals in the United States and are close to dogs in emotional appeal (Rollin, 2000). The treatment of horses by society also has undergone a change from being valued as property in the late 1800 s to being managed as livestock in the 1900 s. By the late 1980 s, the perspective of most Americans had shifted to considering horses as companion animals, and those practices used in managing livestock production, such as processing for food products, are no longer acceptable (Stull, 2008; Koehler 2013). The change in their role and treatment has been paralleled by society's new ethic for animals. This is driven by more urbanized communities with residents who are sensitive to issues of pain and suffering in 
all animals and are favorable to developing more regulations and statues for animal protection (Rollin, 2000). The United States in 2013 had an estimated 10.3 million head of horses and has one of the largest horse populations in the world (Food and Agriculture Organization of the United Nations). The economic impact of the equine industry is robust, providing 1.4 million jobs and over $\$ 39$ billion directly to the economy (Deloitte Consulting 2005; Lenz 2009). However, even though many individuals love and care for horses, there are still horses that become unwanted. According to the American Association of Equine Practitioners, an unwanted horse is an animal which is no longer wanted by their current owner because they are old, injured, sick, unmanageable, fail to meet their owners expectations (e.g. performance, color, breeding), or their owner can no longer afford them (AAEP, 2005). Unwanted horses range from being essentially normal, healthy horses of varying ages and breeds to horses with some type of disability or ailment; horses that are unattractive; horses that fail to meet their owner's expectations for their intended use, such as athletic ability; horses that have behavioral problems, or horses that are untamed or dangerous. In many cases, these horses have had multiple owners, have been shipped from one sale barn, stable, or farm to another, and have ultimately been rejected as eligible for any sort of responsible, long-term care (AAEP, 2005; AVMA 2012).

\section{Reasons for Why Horses become Unwanted}

A 2009 nationwide survey conducted by the Unwanted Horse Coalition identified three scenarios in which horses become unwanted. The primary reason was a change in owner's economic situation (change in employment status, ability to afford the horse, and loss of interest in horse). The second most common scenario involved injury 
or old age of the horse and the third reason was the unmanageable nature of the horse (UWHC, 2009). A 2014 study completed across 26 states by researchers Holcomb and Stull at the University of California Davis that found economic hardship was ranked first for the cause of neglect and abandonment, whereas owner ignorance ranked first for the cause of cruelty in animal control equine investigations. In the study they analyzed the role of U.S. animal control agencies in equine neglect, cruelty, and abandonment investigations. The agencies reported $54 \%$ of owners had experienced financial difficulties that included the loss of a job or home, 39\% lacked sufficient knowledge of horse care, $27 \%$ were physically unable to use or care for the horses because of age or illness, 23\% lacked time, and an equal percentage had lost interest in the horse (Stull, 2014).

The crash of the U.S. economy in 2008 negatively affected employment and home ownership rates, which in turn limited the ability of some owners to provide care for their horses. The Cooperative Extension Service estimated the average cost to care and house a horse in 2008 was $\$ 2,426$ a year (eXtension Foundation, 2008). The costs add up quickly when factoring in feed, farrier cost, veterinary care, vaccinations, boarding, and supplies for the horse. Horses are also social and herd animals. One horse does not fare well by itself and it is suggested that they be kept with at least one other horse. For some, this will amount to a large sum of money to spend on animals (Fernandez et al. 2013). Because of these economic reasons, it is increasingly hard for some owners to keep and maintain horses, as evidenced by the large number of horses becoming unwanted.

Breeders, trainers, and owners seeking to sell horses have been struggling to find buyers. The total population is affected both by the increased lifespan of horses- resulting 
from major advances in health care and nutrition- as well as breeding more horses than the market can absorb (Persechino, 2008). More people turn away from horses when they are not a fit for the job that they want the horse to perform. Horses that have bad habits or "vices" are usually lower on the list of traits owners look for in a horse (McBride and Mills, 2012). Because owners do not want to take the time to find a fitting job for the horse, they look to sell the horse and find one better suited to their needs. Many trainers are also not knowledgeable in multiple disciplines and could therefore be unable to recognize the individual horse's potential in a different environment or a different type of training. Unfortunately for the horse, because there are so many disciplines, trainers rarely have the connections to facilitate the horse's potential and many horses do not get the opportunity to move on to a role where they are better suited (Goodwin, 2012).

\section{Overall Contributing Factors to the Unwanted Horse Population}

Many studies have been completed on underlying factors that have facilitated the unwanted horse population, such as closure of slaughter facilities in the U.S., the economic downturn, and rising cost to care for horses. Horse welfare in the U.S. has in general declined since 2007, as evidence by a reported increase in horse abandonments and an increase in investigations for horse abuse and neglect. The extent of the decline is unknown due to a lack of complete, national data, but states attribute the decline in horse welfare to many factors, most notably the ending of domestic slaughter and the U.S. economic downturn (GAO, 2011).

The U.S. is home to over 10 million horses (FAO stat, 2013). In 2006, the U.S. was the fifth-largest exporter of horsemeat (Sayles, 2009). The U.S. Government Accountability Office (GAO) reported the value of horsemeat exported by American 
equine slaughter facilities in 2006 to be about $\$ 65$ million (GAO, 2011). Before the closure of domestic horse processing in 2007, domestic horse slaughter was part of a profitable enterprise (Durfee, 2009). During 2006, there were three processing plants operating, one in Illinois and two in Texas. Industry experts estimate that the total economic impact of a ban on domestic horse slaughter for export amounts to $\$ 152$ million and \$222 million a year (GAO, 2011). In November 2005, the "Agriculture, Rural Development, Food and Drug Administration, and Related Agencies Appropriations Act of 2005-2006" was signed into law. This appropriation bill included the following paragraph that effectively led to the closure of horse slaughterhouses in the United States.

\section{H. R. $2744-45$}

SEC. 794. Effective 120 days after the date of enactment of this Act, none of the funds made available in this Act may be used to pay the salaries or expenses of personnel to inspect horses under section 3 of the Federal Meat inspection Act (21 U.S.C. 603) or under the guidelines issued under section 903 the Federal Agriculture Improvement and Reform Act of 1996 (7 U.S.C. 1901 note; Public Law 104-127).

However, in February 2006, the three remaining processing facilities in Illinois and Texas were able to continue processing due to a USDA regulation (CFR 353.19) that allowed the remaining processing facilities to circumvent the horse inspection funding ban by paying for their own inspections. The final closure of the three remaining processing facilities did not come until Texas enforced Chapter 149 of the Texas Agriculture Code and Illinois signed H.B. 1711 into law, banning the slaughter of horses for human consumption. Despite the closures, a loophole appeared for supporters of 
domestic horse slaughter in November 2011. The Agriculture Appropriations bill for 2012 was passed by Congress and signed into law without wording that prohibited funding for horsemeat inspections. Several states sought USDA inspection with the realistic possibility of bringing hundreds of jobs to the United States with the renewal of domestic equine slaughter (Geyer and Lawler, 2013). However, the current state of horse slaughter in the U.S. looks bleak for those supporters, as the most recent federal budget includes language prohibiting horse slaughter (Potter, 2014).

Not only were these plants economically profitable before they were closed, but they were a valuable counter-balance to the overproduction of horses (Durfee, 2009). Horse slaughter in the U.S. added revenue, jobs, and more importantly a "humane, economically viable disposal option for unwanted or dangerous horses under careful federal regulation" (Opitz, 2011). Another impact of the domestic horse slaughter ban shows concerns with equine welfare. According the USDA National Agricultural Statistics, about forty-four percent of American slaughter horses are sent to Canadian facilities for humane regulated slaughter, while the remaining fifty-six percent are shipped to Mexico for processing (Lawler et al., 2015). Although there are two European Union (EU) regulated plants in Mexico (International Fund for Horses, 2014), many horses are sent to local Mexican butchers that are known to use less humane methods of slaughter. According to livestock slaughter expert Dr. Temple Grandin, "the worst outcome from an animal welfare perspective is a horse going to a local Mexican abattoir...horses going to totally unregulated slaughter facilities in Mexico is much worse than even a poorly run U.S. plant" (Grandin, 2012). The following excerpt written by Grandin aptly summarizes this aspect of horse slaughter: 
'When the Humane Society of the USA lobbied the government to pass this law, nobody thought about the worse fates that some unwanted horses could suffer. The fates that are worse than slaughter in Texas and Illinois are: 1) longer transport times; 2) transport under substandard conditions in Mexico; 3) being neglected and left to starve in the desert (high hay and grain prices made this problem worse) and 4) being ridden and worked in Mexico until they become totally debilitated. Horse slaughter became such an emotional issue that animal advocates chose to ignore the observations of people in the field that indicated that there are worse fates than slaughter in a U.S. plant".

The horse welfare analysis from the GAO report in 2011 revealed that the cessation of domestic horse slaughter led to an $8 \%$ to $21 \%$ decline in the per head price of horses sold at auctions (GAO, 2011). This could be a clear indication of the burden thrust upon American slaughter horse sellers by finding slaughter facilities across borders. It stands to reason that renewing domestic horse slaughter would reduce transportation costs, thereby increasing slaughter horse prices and revenue generated by U.S. horse sellers, which promotes the welfare of individuals and communities that host horse auctions (Lawler et al. 2015).

In 1971, the Wild Free-Roaming Horses and Burros Act was passed into law. This act provided the necessary management, protection, and control of wild horses and burros in the United States. The Bureau of Land Management (BLM) estimates that 49,209 wild horses, mules, and burros are roaming on BLM-managed rangelands in 10 western states (BLM, 2014). However, the estimated current free-roaming population exceeds the maximum appropriate management level by 22,500 animals. This number is problematic 
in that herd sizes grow rapidly, while BLM holding facilities are almost at capacity. According to the BLM, there are 48,477 animals in short-term corrals and long-term pastures, with a maximum capacity of 50,153 animals. All of these animals require care which subsequently means tax payer money (Lawler et al., 2015). The BLM reports they spent \$44.435 million on gathering, removal, and holding of animals in fiscal year 2014 (BLM, 2014). From 1971 through 2007, the BLM removed over 267,000 wild horses and burros from these lands, and during the same period, under a BLM program that promotes adoptions a approximately 235,700 of these animals were adopted by the public. However, in 2008 the GAO reported there was a steady decline in these adoptions in recent years, which government officials attribute to the large number of domesticated horses flooding the market (GAO, 2008). According to BLM officials, in addition to natural reproduction in wild horse and burro herds, the increasing number of domesticated horses being abandoned on public lands has contributed to this overpopulation problem (GAO, 2011).

The cases of neglect and abuse in the years since closing of the processing plants in the United States have risen (Stull, 2014). According to Keith Dane, director of Equine Protection for the Humane Society of the United States, local officials are seizing large numbers of horses, and rescue organizations are increasingly taking in more animals. He worries, because many of the rescue centers are getting full, the horses are sold to "kill buyers" or left to "perish in barren fields" (Jarvie, 2008). According to shelter worker Heather Robertson, “this is the third year that they've seen a significant increase in animals being surrendered" (Cowan, 2010). In Arkansas, large cases of horse neglect made headlines, as authorities seized 117 hungry, diseased, and neglected horses (Irby, 
2010). In Oklahoma, at least 30 horses were found dead on a ranch in Muskogee County. One Sheriff said, "Some of them have been here for months, and some of them are dying as we speak. They've had three die since they've been here, had to put down three, and they have others that need to be put down. There's just no excuse for what's going on out here. I just don't understand it". Officials in Oklahoma said they have counted at least 100 horses in very poor health, malnourished, and riddled with parasites (Conrad, 2015). In Illinois, 75 registered American Quarter horses were surrendered to non-profit horse rescue organizations when the owner provided insufficient shelters and the operation became insolvent (Bevis, 2014). It is not just large farms that are neglecting or abandoning horses. In Colorado, 10 horses were seized after community members alerted authorities to substandard conditions on the property. When they investigated, authorities found a gruesome site, as one neighbor stated, "I saw a long femur bone underneath a tarp and when I went to lift it, there were the bones of all these dead horses, rotting...The horses that were still alive were locked up in there with all the remains, walking around in about 3 feet of their own manure, with moldy water and no pasture to feed on." (Sinclair, 2014).

The Unwanted Horse Coalition (UHC) estimated 170,000 horses nationwide were abandoned in 2010 (UHC, 2010). The recurring theme of horse neglect has strained available resources to care for the animals. Given the sluggish recovery of the economy, and the financial strain caring for horses entails, the number of abandoned horses may continue increasing until a viable solution is reached to maintain the unwanted horse population (Opitz, 2011). 


\section{Current Methods to Maintain the Unwanted Horse Population}

As awareness increases regarding the number of unwanted horses in the United States, there are many organizations that are attempting to manage the population of unwanted horses. Communities are at the forefront of this movement as they recognize the importance of investigating any report of horse cruelty and neglect (Stull and Holcomb, 2014).The current solutions to manage unwanted horses are intended to find new homes, uses, or humanely euthanize the horse. When horse ownership is no longer a feasible endeavor, there are many different options for the owner.

Equine rescue, retirement, and sanctuary organizations throughout the United States can trace their history to Henry Bergh, who pushed for humane treatment of animals, founded the American Society of the Prevention of Cruelty to Animals (ASPCA) in 1866, and established farms where old horses could retire (Loeper, 1991). Current organizations are expected to play a role in absorbing, caring, and re-homing unwanted horses (Cross, 2008). The oldest and largest retirement organization in the U.S. is the Thoroughbred Retirement Foundation, founded in 1983 to help racehorses who are no longer wanted or who have suffered career-ending injuries. They currently care for more than 1,050 retirees and have found new homes for more than one thousand horses (TRF, 2015). However, not all organizations operate on that large of scale. The 2009 Unwanted Horse Coalition survey revealed that thirty-nine percent of these horse rescues were at maximum capacity and another thirty percent were near capacity. On average, thirty-eight percent of rescues are turning away horses brought to them. A study completed by University of California Davis in 2010 found the average number of horses a rescue or sanctuary currently cares for is 20 horses. Whereas approximately seventy 
percent of the 326 nonprofit organizations had a maximum capacity of 30 or fewer horses, the most common capacity was 11-20 horses, in thirty percent of facilities. Only four percent had a capacity of their facilities for more than 100 horses (Holcomb et al. 2010). This study found the population capacity of the 326 valid non-profit organizations that responded to their survey have a maximum capacity of approximately 13,700 horses nationwide (Holcomb, 2010). However, despite efforts to estimate the number of horse rescues and sanctuaries, there is still no current collective database or even a validated estimate of the total number of equine organizations in the United States available to care for unwanted horses (Holcomb, 2010; Stull et. al. 2014). In conclusion, the UC Davis study found equine rescue and sanctuary facilities appeared to be struggling with insufficient resources to meet the increasing demand for accepting, caring, and finding new homes for unwanted horses in the United States (Holcomb, 2010).

The Kentucky Equine Humane Center was developed in April 2007 in an effort to provide for the unwanted horses of Kentucky. Their mission is to "provide humane treatment and shelter while working as a clearinghouse to seek adoptive homes for all of Kentucky's unwanted horses, regardless of breed" (KyEHC, 2015). This charitable organization aids in ownership education, while providing adoption and shelter for unwanted horses. The Unwanted Horse Assessment Station is a facility at UC Davis School of Veterinary School of Medicine that is designed to take unwanted horses and evaluate them to determine suitability for adoption. When a horse enters the facility, it is categorized into adoption, shelter, or humane euthanasia. The facility is meant to make the best use of every unwanted horse by providing each with a job based on determined capabilities and limitations (UC Davis, 2015). Both facilities' missions are supported by 
recent findings that early detection and intervention with humane cases, and education focusing on the costs and responsibilities associated with horse ownership are key steps towards addressing the issues of the unwanted horse (Beeson, et al. 2013).

Unwanted horses possess value to non-profit riding programs such as therapeuticriding centers for individuals with disabilities, pony clubs, or schools with equestrian curriculum. Many universities such as Colorado State and Texas A\&M accept horse donations to serve in teaching curriculum (Paxton, 2015). The Professional Association of Therapeutic Horsemanship International (PATH Intl) accepts horses as donations to assist in their therapeutic riding programs. Currently more than 4,500 horses of different breeds, ages, and sizes are serving individuals with disabilities. Many horses are donated to PATH Intl because their owners outgrow them, they are retired competitors, or the tax credit the owner receives upon donation is more of a benefit then selling the horse (PATH Intl, 2015).

In addition to placement in a rescue or retirement facility, a horse owner can choose to have the horse chemically euthanized by a licensed veterinarian. This method is common for lame horses, and provides horse owners who can no longer afford their horse or owners who do not wish to keep their horse anymore, a safe humane option. Veterinary cost of euthanasia can range from $\$ 60-100$ followed by the expense of disposing the body. In many instances, due to environmental regulations, horses cannot be buried on site (Evans et al., 2015). According to Ahern et al. (2006) and North et al. (2005) landfills have taken carcasses in the past, but some are now charging fees or banning the practice. According to responses from horse owners in the Unwanted Horse Coalition 2009 survey, the average cost of euthanizing a horse and disposing of its 
carcass was $\$ 385$ in 2008. A study investigating the unwanted horse problem in Minnesota, Wisconsin, and Texas, found the average cost for euthanasia was \$237 and the average cost of rendering was $\$ 168$ per horse. The average age of rendered horses was 18 years with the dominant breed being the American Quarter Horse. The study showed the majority of horses that were chemically euthanized were due to injury and advance age (Beeson, 2013). One organization that assists in euthanasia funding is the Equine Protection Fund in New Mexico. They offer a program, “Trail's End” that subsidizes some veterinary fees and disposal costs for humanely euthanizing suffering horses and other equines (Equine Protection Fund, 2015).

The proliferation of horse rescues and sanctuaries unfortunately serves to propagate the number of unwanted horses in the United States. From an animal welfare perspective, the best possible outcome for an unwanted horse is residency in a rescue or retirement facility. These facilities provide care, nourishment, retraining, and adoption events for their horses, affording them a relaxed humane approach to becoming unwanted (Geyer and Lawler 2013). Olexa, Cossey, and Smallwood (2011) stress that rescue and retirement facilities can "strengthen the equestrian community, create additional revenue base for municipalities, provide an agricultural benefit to the public, and perhaps most importantly, foster a humane alternative for all potentially useful, yet abused, abandoned, and aging livestock. Despite the many benefits horse rescues and retirement facilities offer, their viability as a mechanism for unwanted horse disposal is limited by cost of resources and capacity (Lawler and Geyer, 2015; Olexa et al. 2011). 


\section{Unwanted Horse Population in Illinois}

The horse industry in Illinois generates goods and services valued at over $\$ 1.2$ billion and is home to over 178,463 horses, mules, and donkeys, based on combined data from the American Horse Council and the Horsemen's Council of Illinois (AHC, 2005; Horsemen's Council of Illinois, 2012). There are nearly 64,000 horse owners in Illinois and more than 200,000 residents are involved in the industry as owners, service providers, employees, volunteers, and even more participate as spectators in equestrian events (HCI, 2012). The equine landscape in Illinois displays variation and is diverse. In some areas, breeds and disciplines are localized, while others can be found throughout the state. The equine population has a large economic impact, including equine operations, horse races, horse shows, and trail rides. Within the state of Illinois, the Unwanted Horse Coalition has documented seventeen-horse rescue, sanctuary, and adoption agencies (UHC, 2015). Illinois was also home to the last remaining horseprocessing plant, Cavel International, Inc. in DeKalb, Illinois, which operated for over twenty years. During the time Cavel was operating they averaged processing one thousand head of horses per week (Cavel Int. v. Madigan, 500 F.3d 558 (7th Cir. 2007). In June 2007, the Illinois Horse Meat Act was upheld in the Seventh Circuit court, which ultimately led to shutting down the processing plant. The Illinois Horse Meat Act "prohibits the slaughter of horses for human consumption as well as importing, exporting, selling, giving, or even possessing horsemeat if a person knows or should know that it will be used for human consumption" (Illinois General Assembly (225 ILCS 635/) Illinois Horse Meat Act). 
Illinois resembles other states regarding the many organizations throughout the state that help and support the unwanted horse population. The Illinois Equine Humane Center is a non-profit organization in Maple Park, IL, that provides treatment and shelter while working as a clearinghouse to seek adoptive homes for all of Illinois' unwanted horses. They also work to educate the public and raise awareness for responsible equine ownership so fewer horses end up in crisis (ILEHC, 2015). The Illinois Thoroughbred Horsemen's Association's Galloping Out program provides funding for the rescue, care, rehabilitation, and retraining of thoroughbred racehorses that have raced or trained at Chicago-area races tracks. Galloping Out has re-homed over one hundred thoroughbreds since becoming a non-profit organization in 2010 (Galloping Out, 2015). The Hooved Animal Humane Society (HAHS), in Woodstock, IL, was the first humane society in the United States to focus specifically on large animals, primarily horses. HAHS is a nonprofit organization, founded in 1971, that has a mission to promote the humane treatment of hooved animals through education, legislation, investigation, and legal intervention. HAHS is not only caring for unwanted horses; they have thirty-two State Approved Humane Investigators. These investigators were responsible for two hundred and five investigations in 2012 and one hundred and forty-eight investigations in 2013. In 2012 and 2013, HAHS took in fifty-five new equine that came from criminal prosecutions from neglect, starvation, abandonment, or were running at large throughout the state (HAHS, 2015).

The efforts of many organizations throughout the state help in maintaining the unwanted horse population. However, the efforts of these organizations does not hide the fact that many horses are becoming abused, neglected, and unwanted. In February 2014, 
more than thirty horses were seized from a property in Kane County due to a violation of an owner's ability to provide food and care which led to animal cruelty charges (Raia, 2014). The Hooved Animal Rescue and Protection Service (HARPS) recently partnered with Hands \& Hooves Rescue in Chicago to care for 75 registered American Quarter Horses that were surrendered due to the financial hardship (Bevis, 2014). Some rescue operators say, "A perfect storm of high hay prices, a bad economy, and ineffective government oversight has created a crisis" (Ortiz, 2013). The Horse Rescue of Will County has picked up abandoned horses from the side of the road and roaming through suburban neighborhoods. Their shelters are crowded to capacity with many operations having to turn new unwanted horses away. The Kankakee County Animal Control and Adoption Center has received at least a dozen calls asking for help with horses hit by cars, running at large or suspected of being neglected (Ortiz, 2013).

According to the state's Humane Care for Animals Act, cases of abuse or neglect, known as "humane care calls", are investigated in several ways. County animal control departments have the authority to issues citations and work with owners on improving care. Rescues organizations and animal advocacy staff and volunteers may also be approved by the state to handle abuse and neglect calls. Similarly, sheriffs and police departments can investigate cases and have authority to seize animals when owners are arrested. However, short of an arrest, permission to remove or impound animals must come from the Department of Agriculture's Bureau of Animal Health and Welfare (Illinois Animal Protection Laws, 2015; Ortiz, 2013). In 2002, the Bureau of Animal Health and Welfare had thirty-two employees, compared to twelve currently. The Bureau's budget was slashed from $\$ 7$ million to $\$ 4.6$ million in the same time period. In 
2013, five investigators handled complaints from across the state, with each responsible for as many as fifteen counties. In 2012, 969 humane care complaints were made to the bureau (IAPL, 2015; Ortiz, 2013). Jeff Squibb with the Illinois Department of Agriculture, says “everyone's resources are stretched thin, and there a limit to what we can provide and that if it's not good enough, I suggest individuals contact their lawmakers and tell them to start providing additional resources" (Ortiz, 2013).

Horse industry experts, horse owners, and the media have speculated the number of unwanted horses is increasing in the United States. Some believe the problem is growing larger due to the poor economy, rising costs of feed, the costs of euthanasia and disposal, rescues becoming full, and the laws banning horse processing. Many states have had studies completed to find answers to the growing problem. However, no studies have been completed to assess the unwanted horse population or individual's awareness and perceptions of the problem in the state of Illinois. 


\section{REFERENCES}

Ahern, J.J., Anderson, D.P., Bailey, L.A., Colette, W.A., Neibergs, J.S., North, M.S., Potter, G.D., Stull, C.L. 2006. The unintended consequences of a ban on the human slaughter of horses in the United States. Doctoral Diss. University of California, Davis, California.

Animal Assistance Foundation. 2008. Colorado Unwanted Horse Environmental Assessment Report. http://www.counwantedhorse.org/images/stories /registered/aaf/documents/assessmentreport.pdf.

American Horse Council. 2005. National economic impact of the U.S. horse industry. http://www.horsecouncil.org/national-economic-impact-us-horse-industry.

Beeson, S. K., Weber, W. J., Wilson, J. H., Sigler, D. H., Glunk, E. C., \& Martinson, K. L. 2013. Investigating the unwanted horse problem in Minnesota, Wisconsin, and Texas. Journal of Equine Veterinary Science, 33(5), 384.

Bevis, B. 2014. 75 registered quarter horses abandoned and in desperate need of homes. The Equine Chronicle. October 3, 2014. http://www.equinechronicle.com/75registered-quarter-horses-abandoned-and-in-desperate-need-of-homes/.

Conrad, E. 2015. Officials find dozens of dead, neglected livestock on Muskogee County Ranch. NewsOn6.com. February 8, 2015. http://www.newson6.com/story /28056104/officials-find-dozens-of-dead-neglected-livestock-on-muskogeecounty-ranch.

Cross, L. 2008. Little Brook Farm offers humane alternatives for the "unwanted" horse. The Unwanted Horse Issue: What Now, 46-48.

Deloitte Consulting LLC. 2005. National economic impact of the U.S. horse industry. Technical report prepared for the American Horse Council Foundation. Accessed 15 May 2015. http://www.horsecouncil.org/national-economic-impact-us-horseindustry.

Durfee, L.J. 2009. Anti-Horse Slaughter Legislation: Bad for horses, bad for society. 84 Indianan Law Journal. 353.

Equine Protection Fund. 2015. Trail's end (Humane euthanasia support). http://equineprotection fund.org/. 
Evans, P.A., Bailey, D., Rice, C., Jones, A., Shumway, K., McKendrick, S. 2015. The state of the horse industry since the closing of the horse harvesting facilities.

Extension Utah State University. http://extension.usu.edu/equine/.

eXtension Foundation. 2008. Cost of horse ownership. Retrieved from http://www.extension.org/pages /15642/cost-of-horse-ownership.

Fernandez, Cynthia \& Gadek, Cindy \& Meenan, Lisa \& Fagan, Julie M. 2013. Disaster Preparedness for Animals. Retrieved from http://dx.doi.org/doi:10.7282/ T3930RM3.Food and Agriculture Organization of the United Nations Statistics Division. 2013. Production/Live Animal, Horses, Average Number of Head 1993-2013. http://faostat3.fao.org/browse/Q/QA/E (Accessed 23 May 2015).

Fuentez, N. 2015. Helping horses. The Clovis Independent April 8, 2015. http://www.fresnobee.com/ news/local/article19648002.html.

Galloping Out. 2015. Illinois Thoroughbred Horsemen's Association, Inc. http://www.itharacing. com/home.

GAO. 2008. Bureau of Land Management: Effective long-term options needed to manage the unadoptable wild horses. GAO-09-77. Washington, D.C.: Oct 9, 2008.

Geyer, L. and D. Lawler. 2013. "Yea or Neigh? The Economic, Ethics, and Utility of the Horsemeat Filet." Food Law and Policy 247-274. Goodwin, C., Felter, C. Fagan, J.M. 2012. The Unwanted Horse. Rutgers, The state university of New Jersey. http://dx.doi.org/doi:10.7282/T3251G9N

Grandin, T. 2012. "Answering Questions About Animal Welfare During Horse Slaughter.” Availableonline:http://www.grandin.com/humane/questions.answers. horse.slaughter.html

Grandin, T. 2010. Improving Animal Welfare: A Practical Approach. Wallingford, Oxfordshire, UK: CAB International. 224

Holcomb K.E., C.L. Stull, P.H. Kass. 2010. Unwanted horses: The role of nonprofit equine rescue and sanctuary organizations. American Society of Animal Science. Doi:10.2527/jas.2010-3250.

Hooved Animal Humane Society. 2015. 2013 HAHS Annual Report. http://www.hahs.org/site/epage /60857_665.htm.

House, A.M., 2009. Own Responsibility with the Unwanted Horse Coalition. Florida Equine Institute 2009. http://cflag.ifas.ufl.edu/documents/2009Equine Instit/House.pdf. 
Illinois Equine Humane Center. 2015. http://www.ilehc.org/about-us.html.

International Fund for Horses. 2014. Horse Slaughter: Images and Description, Available online: http:// www.horsefund.org/horse-slaughter-images.php.

Irby, R. 2010. National agencies take control of over 100 horses at Kankey farm. AreaWideNews. December 14, 2010. http://www.areawidenews .com/story/1687808.html.

Jarvie, J. 2008. Drought is a hard time for horses. L.A. Times. January 13, 2008. http://articles.latimes.com/2008/jan/13/nation/na-horses13.

Kentucky Equine Humane Center. 2015. http://www.kyehc.org/home.html.

Kline, K.H. 2012. The Illinois Horse Industry: The Billion-Dollar Fact\$. Horsemen's Council of Illinois. http://hci.wildapricot.org/Resources/Documents /Billion Dollar.pdf

Koehler, B. 2013. It costs how much to get rid of my horse?!? Why the economic downturn has illustrated the need for horse slaughter facilities. Drake Journal of Agriculture Law 18(2013):375.

Lenz, T.R. 2009. The unwanted horse in the United States: An overview of the issue. Journal of Equine Veterinary Science 29(5):253-258

Loeper, J. J. (1991). Crusade for kindness: Henry Bergh and the ASPCA. Atheneum Books.

McBride, S.D., Mills, D.S. 2012. Psychological factors affecting equine performance. BMC Vet Res 2012; 8:180-91. DOI:10.1186/1746-6148-8-180. DOI: $10.1186 / 1746-6148-8-180$

North, M. S., Bailey, D., \& Ward, R. A. 2005. The potential impact of a proposed ban on the sale of US horses for slaughter and human consumption. Journal of Agribusiness, 23(1), 1-17.

Olexa, M. T., Cossey, J. A., \& Smallwood, K. 2011. Protecting Equine Rescue from Being Put out to Pasture: Whether Ranches Dedicated to Abused, Abandoned, and Aging Horses May Qualify for Agricultural Classifications under Florida's Greenbelt Law. Drake J. Agric. L., 16, 69.

Opitz, T. 2011. The tragedy of the horse, American icon. University of Arkansas Journal of Food Law and Policy's 2011: 357. 
Ortiz, V.H. 2013. Horse neglect cases alarm rescue groups/Illinois agency cites staff cuts in slow response; counties handling more calls. Chicago Tribune. March 12, 2013. http://www.chicagotribune.com/dispatcher.front?Query=Horse+neglect+ cases+alarm+rescue+groups\&target=all.

Paxton, J. 2015. Options for your old friend: How to donate a horse to an equestrian college or therapy program. The Equine Chronicle. April 22, 2015. http://www.equinechronicle.com/options-for-your-old-friend-how-to-donate-ahorse-to-an-equestrian-college-or-therapy-program/.

Persechino, T. 2008. Potential solutions and options. Pages 49-57 in the Unwanted Horse Issue: What Now Conf. Washington, D.C.

Potter, L. 2014. A timeline of horse slaughter legislation in the United States. Accessed March 2015. http://www.horsechannel.com/horse-resources/horse-slaughtertimeline.aspx.

Professional Association of Therapeutic Horsemanship International. 2015. Donating your horse to a PATH Intl. therapeutic riding center. www.pathintl.org.

Raia, Pat. 2014. Horses seized in Illinois cruelty case. The Horse. March 17, 2014. http://www.thehorse.com/articles/33547/horses-seized-in-illinois-cruelty-case.

Reece, V.P., T.H. Friend, C.L. Stull, T. Grandin, and T. Cordes. 2000. Equine slaughter transport update on research and regulations. Journal of American Veterinary Medical Association. 206(8):1252-1258.

Rollin, B.E. 2000. Equine welfare and emerging social ethic. Journal of American Veterinary Medical Association. 216(8): 1234-1237.

Rollin, B. (2014). The "unwanted horse" - A modest proposal. The Canadian Veterinary Journal, 55(1), 1234-1236.

Sayles, B.J. 2009-10. The decline of edible equine: A comment on Cavel International Inc. V. Madigan. Ky. J. Equine Agric. \& Nat. Resources L. 103 (2009-2010).

Schiebelhut, A., Schwartz, R., 2015. Illinois Criminal Animal Protection Laws. George Washington University Law School's Animal Welfare Project.

Sinclair, A. 2014. Sheriff's office removes horses from Black Forest property, owner cited. The Gazette. September 23, 2014. http://gazette.com/sheriffs-officeremoves-horses-from-black-forest-property-owner-cited/article/1538070. 
Stull, C.L. 2008. Engineering and performance standards parameters for long distance road transport in the United States: The special case for horses. Veterinaria italiana 44.1 (2007): 223-233.

Stull, C.L., K.E. Holcomb. 2014. Role of U.S. animal control agencies in equine neglect, cruelty, and abandonment investigations. American Society of Animal Science. Doi: $10.2527 /$ jas2013-7303.

Thomas, E. 2010. 50 horses seized in severe Lindale animal cruelty case. KLTV. December 16, 2010. http://www.kltv.com/Global/story.asp?S=13677581.

United States Census Bureau. 2014. Illinois population. http://quickfacts.census.gov/qfd/states/ 17000.html. United States Court of Appeals, Seventh Circuit. 2007. Cavel Interantional, Inc., et. Al., PlaintiffsAppellants, v. Lisa Madigan, et al. Defendants-Appelles. https://www.animallaw.info/case/cavel-intern-inc-v-madigan.

Unwanted Horse Coalition. 2009. 2009 Unwanted Horse Survey. http://www.unwanted horsecoalition.org /resources/UHC_Survey_07Jul09b.pdf.

U.S. Government Accountability Office. 2011. "Horse Welfare: Action Needed to Address Unintended Consequences from Cessation of Domestic Slaughter." 8 GAO-11- 228. 


\title{
CHAPTER III \\ THE PERCEPTIONS OF THE UNWANTED \\ HORSE POPULATION IN
}

\section{ILLINOIS 2015}

\begin{abstract}
A survey to measure the perceptions of the unwanted horse population in the state of Illinois was developed. Horse owners, non-horse owners, and equine industry stakeholders in Illinois were the focus of the study. Participants were surveyed on their perceptions, awareness, and knowledge of the unwanted horse population in the state. Each survey included questions of current knowledge of legislation, background with equine, current methods to control the unwanted horse population, and methods they believe would benefit the population. A block style survey was developed, emailed to a statewide equine association listserv, and advertised through articles online. Findings show that on average horse owners will spend $\$ 3,343$ annually on equine expenditures. There was a significant difference of the average annual cost of horse owners that keep their horse on their own property and owners that do not keep their horse on their property; $\mathrm{t}(304)=9.83, \mathrm{p}<.000$. Findings show $58 \%$ of horse owners view equine as companion animals as opposed to livestock or working animals. Current methods of managing the unwanted horse population were found to be ineffective (2.15) on a fivepoint Likert-type scale (level of effectiveness $1=$ very ineffective through $5=$ very effective). Using frequencies to determine the mean score, horse owners agreed financial
\end{abstract}


hardship (4.68) as the highest rated reason for why horses become unwanted. It was found that reducing the cost of euthanasia, carcass disposal, or rendering (4.07), allowing horse processing facilities to reopen in Illinois (3.83), and creating regional euthanasia centers (3.55), can most effectively manage the unwanted horse population with in the state. The results of this survey may lead to a greater awareness of the unwanted horse population in Illinois. Furthermore, the results may lead to discussion about future legislation within the state on supporting and managing the unwanted horse. Keywords: Equine, Unwanted Horse, Welfare, Illinois, Survey

\section{Introduction}

Unwanted horses are defined by the American Horse Council as those whose current owners no longer want them because they are, "old, injured, sick or unmanageable, or fail to meet the owner's expectations" (American Horse Council, 2009). Horses also become unwanted due to owners' financial inability to provide care for that animal, a need to decrease herd size, or a loss of interest in horse care and associated activities (Unwanted Horse Coalition, 2009).

Traditionally, horse auctions provided a dependable marketplace for disposing of unwanted horses that either did not sell privately or find homes through other means such as rescue, retirement, therapy or an educational setting. The animals offered at auction could find new recreational or agricultural uses, and up until 2007 , about $1 \%$ of the horse population entered the food chain annually, being sent for processing and exported for human consumption (Colorado Unwanted Horse Assessment, 2008).

In September 2007, the last domestic horse processing facility in the United States was closed. The supply of horses now far exceeds the industry's ability to absorb it. With 
no concrete data on the exact number of unwanted horses in the United States, horse industry experts, horse owners, and the media speculate the number of unwanted horses is increasing. Some believe the problem is growing larger due to the poor economy, rising costs of feed, the costs of euthanasia and disposal, capacity rescue populations, and laws banning horse processing. Many states have commissioned studies to find answers to the growing problem. However, no studies have been completed to assess the unwanted horse population or individual's awareness and perceptions of the problem in the state of Illinois.

While there are differing opinions and wide speculation regarding the unwanted horse population in other states and across the nation, the goal of this research was to discover the level of individuals' awareness of the unwanted horse population specifically in Illinois. The study's scope assessed individuals in Illinois because there is little information on unwanted horses in the state.

The purpose of this research was to assess the level of individuals' knowledge and perceptions of the unwanted horse population in Illinois. Horse owners, non-horse owners, and equine industry stakeholders were surveyed to determine their current awareness of the unwanted horse population. These three participant groups were also surveyed to determine their perceptions of the unwanted horse and methods used to maintain the population in Illinois.

\section{Materials and Methods}

Approval to administer survey to human subjects was obtained from Illinois State University’s Institutional Review Board (Protocol 14133528). 


\section{Study Design}

A block-style survey was developed to assess the awareness and the perceptions of the unwanted horse population and of current methods to maintain the population in Illinois. The survey was focused on the residents of Illinois, categorized into three groups as horse owners, non-horse owners, and equine industry stakeholders (Appendix A). The final version of the survey consisted of several types of questions including rank order, closed-ended multiple choice and dichotomous questions, fill in the blank, and open ended questions with the answer option of "other" including a comment response. The term "unwanted horse" in the survey refers to the state of the animal in which the horse is no longer wanted by their current owner because they are old, injured, sick, unmanageable, fail to meet their owners expectations (e.g. performance, color, breeding),

or their owner can no longer afford them. The term "neglected" refers to the conditions of malnourishment, starvation, whereas "abused" includes cruelty, torture, and physical abuse.

The Horsemen's Council of Illinois (HCI) agreed to assist in distributing the survey to their listserv. The listserv included email addresses of $445 \mathrm{HCI}$ members, 65 individuals who attended the 2015 Illinois Horse Fair, and 3,274 individuals with general interest in HCI. The survey was distributed to a total of 3,758 individuals from the HCI listserv, which was composed of horse owners, non-horse owners, and industry stakeholders in HCI's listserv.

In anticipation of receiving data for only a select group of participants, Illinois Farm Bureau (IFB) was contacted to aid in the distribution of the survey. An article was published in IFB's print publication FarmWeek and online version FarmWeekNow.com 
(Appendix B). The Illinois Agriculture Association publishes FarmWeek for their farm operator members. The article was published with a link to the online survey for individuals to click on or allow them to type into their browser. Brownfield Ag News, an affiliate of IFB, contacted the researcher for a radio interview and online article feature. Brownfield Ag News for America, includes Brownfield Ag News radio networks and Brownfieldagnews.com. Brownfield has contractual partnerships with more than 350 affiliate radio stations in Illinois, Iowa, Indiana, Missouri, Wisconsin, Nebraska, Ohio, and South Dakota. The article and radio interview were published online at brownfieldagnews.com, and posted to their Facebook page where individuals were able to share the story online. The article included a web link to the online survey allowing individuals to participate in the research study (Appendix C). The link was shared multiple times by different individuals and Illinois State's Department of Agriculture Facebook page to aid in distributing information on the survey.

This concurrent mixed methods exploratory research was carried out in a block survey method. The sample was surveyed using Select Survey (Kansas City, Missouri) as the survey tool and the data was analyzed using SPSS (Armonk, New York). Surveys were anonymous and reported in aggregate.

\section{Threats to Validity}

Threats to validity present in this study include the researcher, survey respondents, the survey instrument, and the statistical software. The researcher is an internal threat to validity. The researcher is a horse owner and is involved in the equine industry and could have introduced bias during the creation of the survey instrument. The survey respondents qualify as external threats to validity. If the participants choose 
answers incorrectly, are not honest with their answers, or skip questions, there is a potential for skewed data. There is a potential of nonresponse bias with the different participants when using an Using SPSS, the tests show valid responses.

Statistical error could occur, but through the use of Select Survey and SPSS the threat to statistical conclusion validity should decrease. Statistical errors could be due to data being incorrectly entered, analytical and interpretation error, and other statistical errors. Multiple resources were located and used to confirm accurate analyses of the data.

\section{Survey: Illinois Horse Owners, Non-Horse Owners, and Equine Industry Stakeholders}

Participant Recruitment. The current population in the state of Illinois is 12.88 million (U.S. Census Bureau, 2014). There are nearly 64,000 horse owners in the state harboring some 178,463 horses, mules, and donkeys, based on a combination of American Horse Council and Horsemen's Council of Illinois data (AHC, 2012; HCI, 2012). The population of 3,758 individuals from the Horsemen's Council of Illinois listserv were sent an email to participate in the research study. Out of the 3,758 emails sent by HCI, 960 opened the email, 396 clicked on the survey link, and 206 emails were bounced back or opted out of communication as of April 26, 2015. There was an article published to advertise the research in FarmWeek and FarmWeek.com. Over 407,388 Illinois Farm Bureau members have access to the printed version of FarmWeek and the online version FarmWeekNow.com. Brownfield Ag News published a short article and conducted a radio interview to aid in advertising the research study. Readership and broadcast ratings are unavailable, making it hard to determine the number of residents reached by either mode. 
Horse Owner Participants and Survey Design. There was a total of three hundred and sixty horse owners that participated in the survey. The survey included 3339 questions depending on horse ownership and activities that accompany ownership. The horse owner portion of the survey consisted of seven initial demographic and status of horse ownership questions, nine fill in the blank, five check all that apply, seven Likert scale, seven yes or no, and three multiple choice questions. Horse owners were asked about what purpose their horse(s) served, where the animal was kept, if they have had to euthanize, sell, or donated a horse, what year and what the cost was for those services, and what they believe the average annual cost is to care for a horse. Furthermore they were asked how they view equine, if they were concerned with the welfare and horses becoming unwanted, knowledge of state and national laws, personal awareness of unwanted horses, current methods to maintain the population, where they are getting their current information, and who has the primary responsibility. They were then asked to rate the major reasons why horses become unwanted, overall contributing factors to the population, and how effective the current methods to maintain the population are. Finally, they were asked to provide suggestions to maintaining the unwanted horse population.

Non-Horse Owner Participants and Survey Design. There was a total of eighty-seven non-horse owners who participated in the survey. The survey included 2022 questions depending on if they were previous owners. The non-horse owner portion of the survey consisted of seven initial demographic questions and status of horse ownership questions, one fill in the blank, one check all that apply, seven Likert scale, three yes or no, and three multiple choice questions. If the individual previously owned a horse they were asked why they no longer have the animal. Each participant was then asked their 
view point on equine, if they are concerned with horse welfare and unwanted horses in Illinois, their knowledge of state and national laws, what they believe the number of unwanted horses is doing, who has the primary responsibility to manage the population, and how effective the current methods are to maintain the population. They were then asked to rate the major reasons for why horses become unwanted, overall contributing factors to the population, and how effective different methods would be to manage the unwanted population in Illinois. Finally, they were asked for their suggestions to managing the unwanted horse population.

Equine Industry Stakeholder Participants and Survey Design. There was a total number of forty equine industry stakeholders who participated in the survey. The survey included 35-44 questions depending on status of horse ownership. The industry stakeholder portion consisted of seven initial demographic and status of horse ownership questions, nine fill in the blank, six check all that apply, seven Likert scale, nine yes or no, and six multiple choice questions. Industry stakeholders were asked what their occupation is in the industry, if they work with horses on a daily basis, if they currently or have ever owned a horse and what the animals purpose was. If current horse ownership was determined, they were asked how many, what breed, and where they are housed. Stakeholders who currently own or have owned horses were asked if they have ever euthanized, sold, or relinquished a horse, what the reasoning was and total cost. All were asked if they considered themselves a horsemen, how they view equine, if they are concerned with the welfare and unwanted horses in Illinois, current knowledge of state and national laws, if they are personally aware of unwanted horses, what they believe the current number of unwanted horses is doing, their knowledge of current methods to 
maintain the population, who has the primary responsibility, where they are getting their current information on unwanted horses, and how effective the current methods are to maintaining the population. They were asked to rank the major reasons for why horses become unwanted, the overall contributing factors, and possible solutions for managing the population in Illinois. Finally, they were asked to give their suggestions for managing the unwanted horse population.

\section{Survey Dissemination}

The survey was advertised through email communication, an article in FarmWeek, FarmWeekNow.com, a radio interview and an online article with Brownfield Ag News. The Brownfield Ag News article was shared on Facebook by Illinois State University's Agriculture Department page and numerous other individuals. All participants were guided to follow a link to participate in the online survey. The email from the Horsemen's Council of Illinois was sent on April 8, 2015. The article in FarmWeek and FarmWeekNow.com was published April 14, 2015. The radio interview and web article was published April 18, 2015 on Brownfield Ag News website. The survey was closed May 15, 2015.

\section{Statistical Analysis}

Data was collected via Select Survey. Descriptive statistics were run on Likertscale questions, open-ended numeric questions, and quantitative data. Qualitative responses were used to support quantitative data. In SPSS, the data was analyzed and interpreted using descriptive statistics (mean, median, mode, frequency, and range). 


\section{Results}

Participant Group 1: Illinois Horse Owners. Three hundred and ninety seven horse owners from across the state of Illinois responded to the Perceptions of the Unwanted Horse Population survey (Table 1). Thirty-seven surveys were either partially completed, not of consenting age, or not from the state of Illinois for a retention rate of $90.6 \%$.

Demographics. Of the three hundred and sixty horse owner respondents, two hundred and eighty nine or $80.3 \%$ were female, sixty-five or $18.1 \%$ were male, and six did not respond. The average age of respondents was 55 years old. The minimum age was 18 years old and the maximum age was 82 years old. Two hundred and sixty six or $74 \%$ of respondents reported a household income ranging from $\$ 25,001$ to $\$ 199,999$. There was $9.7 \%$ respondents reporting greater than $\$ 200,000$ and $3.9 \%$ reporting less than $\$ 25,000$ household income (Table 2). The survey respondents were asked about their education levels and ninety-six individuals or $26.7 \%$ of respondents reported they have completed a four-year college degree, $18.6 \%$ of respondents completed some college, and 16.9\% have completed a Master's degree (Table 3). The survey respondents were divided into six regions according to zip code $(1=$ Northwest, $2=$ Central Northwest, $3=$ East Central, 4= West Central, 5=South, $6=$ North East). The region with the highest respondent rate was region six, Chicago and the suburbs of Chicago with $28 \%$ or ninetyeight individuals (Table 4).

Horse Ownership. Of the Illinois horse owners surveyed, there was a total of 1,516 equine and 1,428 horses represented. The average number of equine per horse owner was 4.2 An independent samples t-test was conducted to compare the Chicago area region to the remaining regions in the state. There was a significant difference in the 
number of horses owned in the Chicago area region that keep $(\mathrm{M}=3, \mathrm{SD}=2.15)$ and horse owners that live in the rest of the state $(\mathrm{M}=5, \mathrm{SD}=6.11)$ conditions; $\mathrm{t}(341)=3.23$, $\mathrm{p}<.000$ (Table 10). These results indicate horse owners that live in the Chicago area are more likely to own less horses than the rest of the state. Of those equines represented, the most prevalent breeds were American Quarter Horses (25\%), Tennessee Walking Horses (10.0\%), and Paints or Pintos (8.4\%) (Table 5). Horse owners reported that the main purpose of their horse is for recreational riding, trail riding, or pleasure $(81.7 \%)$, for participating in shows or competitive horse events (34.4\%), and breeding $(9.4 \%)$ (Table 6). Open ended responses for the "other" response included "pet", "rare breed protection", "retired", and "yard ornament" (Appendix F).

Responding to where their horses are kept, $69.4 \%$ of owners stated keeping their horses on their own property compared to $30.6 \%$ who keep their horses at a boarding or training facility, or a relative or friend's property. Horse owners reported a total average annual equine expenditure (incudes feed, boarding, veterinarian bills, and any other basic necessity costs) at a minimum of $\$ 100$ to a maximum of $\$ 25,000$ per horse, with an average of $\$ 3,343$ spent annually. An independent sample t-test was conducted to compare where participants keep their horses and their total average annual equine expenditure. There was a significant difference in the average annual cost of horse owners that keep their horse on their own property $(\mathrm{M}=\$ 2,194, \mathrm{SD}=2,375)$ and horse owners that do not keep their horses on their own property $(\mathrm{M}=\$ 5,910, \mathrm{SD}=\$ 4,196)$ conditions; $\mathrm{t}(304)=9.83, \mathrm{p}<.000$ (Table 7). There was an independent sample t-test conducted to compare the total annual equine expenditures of horse owners in the Chicago area to horse owners in rest of the state. There was a significant difference found 
in the total expenditure of Chicago area horse owners $(\mathrm{M}=4,639, \mathrm{SD}=\$ 4,677)$ compared to the rest of the state $(M=2,823, S D=\$ 2,817)$, conditions; $t(294)=-4.06, p<.000$ (Table 8). These results show the differences in expenditures of horse owners who board their horse somewhere other than their property, and the difference in prices in a more populous urban area of the state. An independent samples t-test was conducted to compare the total number of equine owned to where owners board their horses. There was a significant difference in the number of horses owned by those who do not keep their horses on their own property $(\mathrm{M}=2, \mathrm{SD}=1.582)$ and owners who keep their horses on their property $(M=5, S D=5.997)$ conditions; $t(354)=-5.550, \mathrm{p}<.000$ (Table 9). Horse owners who board their horses on their property are more likely to own more equine. A chi-squared test was performed on where horse owners keep their horses and the zip code regions of survey. A significant relationship was found between individuals who keep their horses on their property and those that do not, and the six zip code regions within the state, $\mathrm{X}^{2}(1, \mathrm{~N}=343)=7.537, \mathrm{p}=.006$. Results show horse owners in the Chicago area are more likely to board their horses somewhere besides their own property (Table 10).

Euthanasia. A majority of respondents (64.4\%) reported they have had to euthanize a horse. The earliest year being reported in 1971 and the latest being 2015. One hundred and sixty-nine (46.9\%) individuals reported having to euthanize a horse from the years 2007-2015 (Table 11). Of the individuals that have had to euthanize a horse, average cost to euthanize amounted to $\$ 692$ (Table 12). All horse owners reported to their knowledge that the average cost to euthanize and dispose of a horse in Illinois is \$680 (Table 13). An independent samples t-test was conducted to compare horse owner's knowledge of the average cost to euthanize and dispose of a horse, and where their horses 
are kept (personal property or not on their property). There was a significant difference in the knowledge of euthanasia and disposal cost for horse owners who do not keep their horses on their property $(\mathrm{M}=\$ 577, \mathrm{SD}=\$ 441)$, and euthanasia and disposal costs for horse owners who do keep their horses on their property $(\mathrm{M}=\$ 432, \mathrm{SD}=256)$ conditions; $t(88.9)=2.61, p=.011($ Table 7). These results show horse owners that board their horses on their own property believe the cost to euthanize and dispose of a horse is less than those horse owners that board their horse somewhere else. Another independent samples t-test was conducted to compare the Chicago area respondents to all other respondents within Illinois on the total cost to euthanize their horse. Results showed a significant difference in the price paid by other regions within the state $(\mathrm{M}=\$ 334, \mathrm{SD}=459)$ and horse owners within the Chicago area $(M=596, S D=602)$, conditions; $t(173)=-3.12$, $\mathrm{p}<.00$ (Table 7). These results suggest Chicago area horse owners are likely to spend more on euthanasia and disposal costs.

Sold. Two hundred and forty $(66.7 \%)$ respondents reported that they have sold a horse. Of those respondents $20.3 \%$ reported they sold their horse as a training prospect. The open-ended responses for the "other" reason for selling their horse included, "bought a different horse and can only afford one", "breed, raise and train to sell", "moved", "downsizing herd", "horse not suitable for our family", "more appropriate for another discipline", "sold to other horse owner", and "sold to make money" (Appendix G).

Relinquished or Donated. A majority of respondents (76.4\%) reported they have never relinquished or donated a horse. Seventy (19.4\%) individuals reported they donated or relinquished their horse to an organization such as a rescue, adoption, or retirement facility, or a university, vet school, or riding facility. Thirty-three individuals 
responded to the open-ended "other" response and included: "4-H project", "gave away to good homes because could not sell", "riding school", "handicapped riding center", "lesson horse", and "therapy" (Appendix H). Of the individuals that have donated or relinquished a horse, owners reported in an open-ended response the name of the organization they relinquished or donated include: “4-H”, "Danada Equestrian Center", “Galloping Out”, "Midwest Horse Welfare Foundation”, "Purdue University Veterinary School”, “Salem Ranch”, “Southern Illinois University”, “Star Therapy program”, "University of Illinois", and "Wounded Warriors" (Appendix I).

Perceptions of Equine and Unwanted Horses in Illinois. Horse owners were asked to select how they view equine, $58.3 \%$ reported they view equine as companion animals whereas, $33 \%$ reported viewing equine as livestock or working animals. Respondents were asked on a three-point scale $(1=$ not at all, $2=$ somewhat concerned, $3=$ very concerned) how concerned they are of the welfare of horses and unwanted horses in Illinois. Horse owners rated their concern of horse welfare and unwanted horses in Illinois with mean scores of 2.53 and 2.61 respectively.

Survey respondents were asked about their current knowledge of the Illinois Horsemeat Act (225 ILCS 635) which state horse slaughter is illegal in the state and the Public Law No: 113-76, which prohibits the pay of salaries for personnel at horse processing facilities in the U.S. A majority (75.8\%) reported they knew about the Illinois Horsemeat Act before taking the survey (Illinois General Assembly, 2007). However, the $53 \%$ of respondents did not know about the Public Law No: 113-76 that was passed in the $113^{\text {th }}$ Congress in January 2014 , stating it prohibits the pay of salaries or expenses of personnel at horse processing facilities in the United States (Congress, 2013). 
The majority (53\%) of horse owners reported they were personally aware of neglected or abused horses in the state. Respondents were asked about their current perceptions of the number of horses being euthanized, abused, or neglected in the state. A four-point Likert-type scale ( $0=$ no change, $1=$ decreasing, $2=$ increasing, $3=I$ don't know) to rate the trend. The mean rating was 2.1 suggesting the number of euthanized, abused, or neglected horses in Illinois is increasing.

Primary Responsibility. Horse owners were asked to select who they believe has the primary responsibility to manage the unwanted horse population. The majority (50.3\%) reported horse owners have the primary responsibility for managing the population (Appendix K). The two other participant groups, non-horse owners and equine industry stakeholders responded with similar rankings (Appendix D \& E).

Information on Unwanted Horses. Respondents were asked to select where they are currently getting their information on unwanted horses. The highest rated responses were social media (37.5\%), such as Facebook and Twitter, printed or online equine trade publication (31\%), followed by humane and animal rights groups (26\%). Through an open-ended question horse owners were asked what "other" sources they are receiving their information about unwanted horses and responses included: word of mouth, emails from equine rescue groups, general news and media, Horsemen's Council of Illinois, and personal experience (Appendix L). Equine industry stakeholders responded with similar rankings (Appendix E).

Major Reasons for Why Horses Become Unwanted. Horse owners rated the major reasons for why horses become unwanted on a five-point Likert-type scale $(1=$ strongly disagree, $2=$ disagree, $3=$ neutral, $4=$ agree, $5=$ strongly agree). Using 
frequencies to find the mean score, the highest ranked reasons were financial hardship (4.7, change in employment status (4.35), and horse was unmanageable (4.32). The lowest ranked reason was change in discipline or riding style (3.14) (Table 16). Nonhorse owners agreed with horse owners and ranked financial hardship (4.56) as the major reasons (Appendix F).

\section{Overall Contributing Factors to the Unwanted Horse Population.}

Respondents were asked to rate the overall contributing factors to the unwanted horse population on a five-point Likert-type scale $(1=$ strongly disagree, $2=$ disagree, $3=$ neutral, 4= agree, 5= strongly agree). Using mean scores, horse owners top rated responses were the downturn in the economy (4.49), the cost to maintain a horse (4.38), and owner unaware of what it takes to own a horse (4.34) (Table 17). Non-horse owners and equine industry stakeholders responded with similar top rankings (Appendix D \& E).

Perceptions of the Current Methods. Horse owners were asked to use a fivepoint scale $(1=$ very ineffective, $2=$ ineffective, $3=$ neutral, $4=$ effective, $5=$ very effective $)$ to rate their current perceptions of the current methods of managing the unwanted horse population. Respondents rated the current methods of managing the unwanted horse population with a mean score of 2.16 , suggesting the perception of the current methods to be ineffective. Respondents were also asked about their knowledge of current methods to control the unwanted horse population in Illinois. The most selected methods were euthanasia (205), adoption facilities (199), and donation to a university or educational program (144) (Table 18). Respondents also provided “other" responses of current methods to control the population in Illinois and responses included: auction, donation to a riding program, there is no appropriate method, and ship out of state (Appendix $\mathbf{J}$ ). 
Perceptions of Effective Methods. Respondents used a five-point Likert-type scale ( $1=$ =very ineffective. $2=$ ineffective, $3=$ neutral, $4=$ effective, $5=$ very effective) to rate different methods to manage the unwanted horse population. The highest mean ratings were to reduce the cost of euthanasia, carcass disposal, or rendering (4.07), allow horse processing facilities to reopen in Illinois (3.83), and create regional euthanasia centers (3.55) (Table 19). Non-horse owners and equine industry stakeholders that responded to the survey question rated similar top three responses (Appendix D \& E).

\section{Suggestions}

Horse owners were asked through an open-ended question about any suggestions they have for managing the unwanted horse population and responses included: stallion registry, allow horse processing facilities to reopen, offer education on options available, encourage humane horsemeat processing, access to affordable methods, hold horse owners more responsible, register all breeders within the state, and higher penalties for abuse and neglect cases. When analyzing the 151 open-ended responses provided there were two major reoccurring themes, forty-three (28.5\%) open-ended responses mentioned re-opening horse processing facilities in Illinois and the U.S., and thirty (20\%) mentioned providing more education opportunities for new and current horse owners (Appendix M).

\section{Limitations to the Study}

The non-horse owners and the equine industry stakeholder groups were the limiting factors to this research study. There is no equine stakeholder database that lists individuals involved in the industry within the state. The non-random convenience sampling method used does not provide an adequate representation of the horse owner 
population in Illinois. The methods used to advertise the study online in different publications and social media pages to survey participants were not adequate to attain a respectable representation of the non-horse owner population, Illinois equine industry stakeholder, and other horse owners in the state. Data from these two groups were only used as supporting data for the horse owner group (Appendix D \& E).

\section{Discussion}

The results of this survey point out the importance of understanding current perceptions of the individuals who are involved with equine on a daily basis. Four is the average number of equine an individual will own in Illinois, and they spend on average $\$ 3,343$ annually on each individual equine. The perceptions of horses have changed over the years, resulting in fifty eight percent of Illinois horse owners viewing equine as companion animals supporting the results found by Rollin in 2000. There was a significant difference in the average annual cost of a horse for Illinois horse owners. Horse owners that keep their horses on their own property spend less than the horse owners that do not keep their horses on their property $(\mathrm{p}<.000)$. There was also a significant difference in the number of horses owned by individuals who do not keep their horses on their own property and owners who do keep their horses on their property. Horse owners that do not keep their horses on their own property are found to own fewer horses than those individuals who do keep them on their property $(\mathrm{p}<.000$. $)$.

There were less than twenty percent of horse owners that have relinquished or donated their horse to an organization such as a rescue, adoption, or retirement facility or a university, vet school, or other organization. Many horse owners believe the overall contributing factor to the unwanted horse population is the downturn in the economy 
which points to the major reason for why horses become unwanted is because the owner has a financial hardship. The financial strain brought on by owning a horse is not only a burden to horse owners, but also equine rescue facilities or other organizations when the horse becomes unwanted.

Horse owners are concerned with the welfare of horses and horses becoming unwanted in the state. The majority of horse owners were found to have a high level of awareness of current laws and methods to maintain the unwanted horse population in Illinois. Sixty-three percent of horse owners believe the current methods to maintain the unwanted horse population are ineffective, and fifty-three percent are personally aware of neglected or abused horses in the state. Even though the majority of horse owners are aware of the problem there is no clear solution. Current horse owner perceptions suggest the most effective method to control the population is to reduce the cost of euthanasia, carcass disposal, or rendering. However, the majority of horse owners believe re-opening horse processing facilities and providing educational programs on horse ownership would help maintain the current unwanted horse population in Illinois.

The results of this survey may lead to a greater awareness of the unwanted horse population in Illinois. Furthermore, the results may lead to discussion about future legislation within the state on supporting and managing the unwanted horse.

Recommendations for future research would be to evaluate and compare how horse owners, non-horse owners, and equine industry stakeholders view unwanted horses. Assessing how effective educational methods are to teaching current and future horse owners about horse ownership could provide a greater insight of the positives and 
negatives of current educational methods. If this research were to be repeated, there needs to be greater emphasis on methods used to contact participants and distribute the survey. 


\section{LITERATURE CITED}

American Horse Council. 2005. National economic impact of the U.S. horse industry. http://www.horsecouncil.org/national-economic-impact-us-horse-industry.

Congress.gov. 2013. H.R. $3547-113^{\text {th }}$ Congress (2013-2014). https://www.congress. gov/bill/113th-congress/house-bill/3547

Illinois General Assembly. Illinois Horsemeat Act (225ILCS 635/). http://www.ilga.gov/ legislation/ilcs/ilcs3.asp?ActID=1381\&ChapterID=24.

Kline, K.H. 2012. The Illinois Horse Industry: The Billion-Dollar Fact\$. Horsemen's Council of Illinois. http://hci.wildapricot.org/Resources/Documents/Billion Dollar.pdf

Rollin, B.E. 2000. Equine welfare and emerging social ethic. Journal of American Veterinary Medical Association. 216(8): 1234-1237

Unwanted Horse Coalition. 2009. 2009 Unwanted Horse Survey. http://www.unwanted horsecoalition.org /resources/UHC_Survey_07Jul09b.pdf. 


\section{CHAPTER IV}

\section{CONCLUSIONS TO THE THESIS EXPERIENCE}

Based on the results obtained from the Illinois horse owner survey it can be reasoned that the unwanted horse population in Illinois is a major concern to the Illinois equine industry. There was positive survey feedback from current horse owners in the state suggesting that the current unwanted horse population can be curbed and even reduced.

There are nearly 64,000 horse owners in Illinois and more than 200,000 residents are involved in the industry as owners, service providers, employees, volunteers, and even more participate as spectators in equestrian events (HCI, 2012). The findings in this research should allow for a better understanding of the individuals involved in the industry and the equine population as a whole. The biggest need is for a joint effort within the state to address the current need for different methods to maintain the unwanted horse population. Research may help further understand perceptions and current knowledge of unwanted horses, which would allow for the state to develop and implement new strategies to maintain the population.

Contacting and distributing the research survey to non-horse owners and equine industry stakeholders was difficult because of limited access to contact information or methods to distribute the survey. Due to the difficulty in contacting research participants, 
non-horse owner and equine industry stakeholder responses were too low to be statistically valid. 


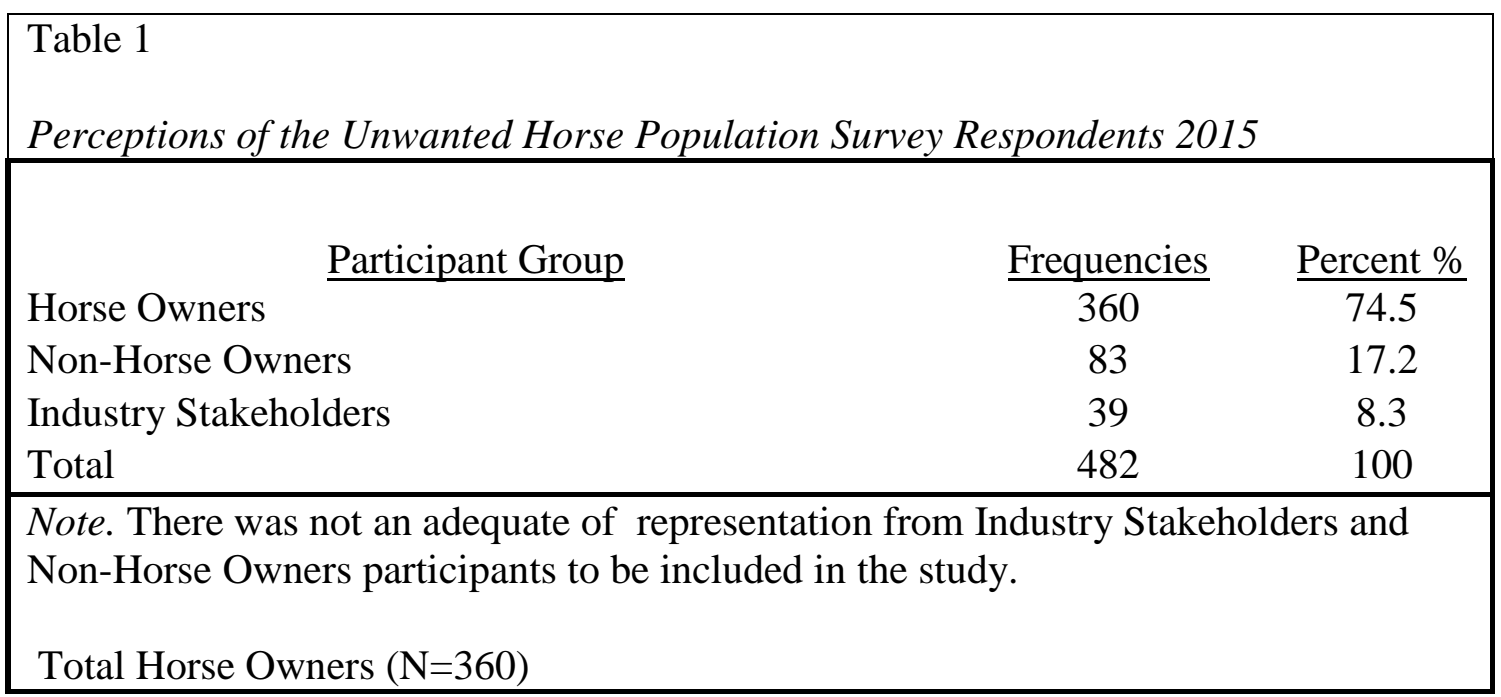




\begin{tabular}{|lcc|}
\hline \multicolumn{4}{|l|}{ Table 2} & & \\
\hline \multicolumn{1}{|c|}{ Household Incomes of Survey Horse Owner Respondents } & \\
\hline \\
Did not respond & $\frac{\text { Frequency }}{45}$ & $\frac{\text { Percent } \%}{12.5}$ \\
Less than $\$ 25,000$ & 45 & 12.5 \\
$\$ 25,001$ to $\$ 49,999$ & 14 & 3.9 \\
$\$ 50,000$ to $\$ 99,999$ & 47 & 13.1 \\
$\$ 100,000$ to $\$ 199,999$ & 119 & 33.1 \\
Greater than $\$ 200,000$ & 100 & 27.8 \\
Total $(\mathrm{N}=360)$ & 35 & 9.7 \\
\hline
\end{tabular}




\begin{tabular}{|lcc|}
\hline Table 3 Horse Owner Survey Respondent Education Levels 2015 & & \\
\hline \multicolumn{1}{|c}{ Education Level } & Frequency & Percent \% \\
Did not respond & 2 & 0.6 \\
No formal education & 1 & 0.3 \\
Some grade school & 1 & 0.3 \\
Completed grade school & 1 & 0.3 \\
Completed high school & 37 & 10.3 \\
Completed two-year college degree & 46 & 12.8 \\
Some college & 67 & 18.6 \\
Completed four-year college degree & 96 & 26.7 \\
Some graduate work & 26 & 7.2 \\
Master's degree & 61 & 16.9 \\
Professional degree & 14 & 3.9 \\
Doctorate degree & 8 & 2.2 \\
Total & 360 & 100.0 \\
\hline
\end{tabular}


Table 4

Horse Owner Respondent Zip Code Regions 2015

\begin{tabular}{|c|c|c|c|}
\hline Region & Zip Codes & & $\frac{\text { Number of }}{\text { Respondents }}$ \\
\hline$\underline{\#}$ & (first 3 digits) & $\underline{\text { Mailing Centers }}$ & in region \\
\hline 1 & $\begin{array}{c}610,611,612, \\
613\end{array}$ & Rockford, Rock Island, LaSalle & 46 \\
\hline 2 & $\begin{array}{c}614,615,616, \\
617\end{array}$ & Galesburg, Peoria, Pekin, Bloomington & 79 \\
\hline 3 & $\begin{array}{c}609,618,619, \\
624\end{array}$ & Kankakee, Champaign, Effingham & 32 \\
\hline 4 & $\begin{array}{c}623,625,626, \\
627\end{array}$ & Springfield, Quincy & 47 \\
\hline 5 & $\begin{array}{c}620,622,628, \\
629\end{array}$ & East St. Louis, Centralia, Carbondale & 48 \\
\hline 6 & $\begin{array}{l}600,603,607 \\
601,604,608 \\
605,602,606\end{array}$ & $\begin{array}{c}\text { Northern Chicago suburbs, Northwest } \\
\text { Chicago suburbs, Far South Chicago } \\
\text { suburbs, Western Chicago Suburbs, } \\
\text { Evanston, Chicago }\end{array}$ & 98 \\
\hline Total & & & 350 \\
\hline
\end{tabular}




\begin{tabular}{|c|c|c|c|c|c|}
\hline $\begin{array}{l}\text { Table } 5 \\
\text { Total Number of Horses, Equine, }\end{array}$ & & s Owned b & & & \\
\hline \multicolumn{6}{|c|}{$\frac{\text { Total Number of Horses, Equine, and Breeds Owned by Horse Owner Respondents }}{\text { Minimu Maximu }}$} \\
\hline & $\underline{\mathrm{N}}$ & $\underline{\mathrm{m}}$ & $\underline{\mathrm{m}}$ & $\underline{\text { Sum }}$ & $\underline{\text { Mean }}$ \\
\hline Total number of horses owned. & $\begin{array}{c}33 \\
7\end{array}$ & 1 & 50 & 1428 & 4.24 \\
\hline Total number of equine owned. & $\begin{array}{c}36 \\
0\end{array}$ & 1 & 50 & 1516 & 4.21 \\
\hline & & $\underline{\underline{\text { Minimu }}}$ & $\underline{\underline{\text { Maximu }}}$ & & \\
\hline$\underline{\text { Breeds }}$ & $\underline{\mathrm{N}}$ & $\underline{\mathrm{m}}$ & $\underline{\mathrm{m}}$ & $\underline{\text { Sum }}$ & Mean \\
\hline American Quarter Horse & $\begin{array}{c}\overline{16} \\
0\end{array}$ & 0 & 32 & 379 & 2.37 \\
\hline American Saddlebred & 37 & 0 & 4 & 21 & .57 \\
\hline Appaloosa & 59 & 0 & 13 & 55 & .93 \\
\hline Arabian or Half Arabian & 79 & 0 & 10 & 119 & 1.51 \\
\hline Crossbreed & 48 & 0 & 4 & 39 & .81 \\
\hline Donkey & 41 & 0 & 3 & 23 & .56 \\
\hline Draft & 44 & 0 & 17 & 47 & 1.07 \\
\hline Miniature Horse & 46 & 0 & 2 & 26 & .57 \\
\hline Morgan & 43 & 0 & 19 & 50 & 1.16 \\
\hline Mule & 33 & 0 & 2 & 10 & .30 \\
\hline Paint or Pinto & 93 & 0 & 8 & 126 & 1.35 \\
\hline Standardbred & 38 & 0 & 10 & 41 & 1.08 \\
\hline Tennessee Walking Horse & 81 & 0 & 23 & 151 & 1.86 \\
\hline Thoroughbred & 49 & 0 & 30 & 71 & 1.45 \\
\hline Welsh Pony or Cob & 40 & 0 & 9 & 32 & .80 \\
\hline Other & $\begin{array}{c}12 \\
7\end{array}$ & 0 & 48 & 310 & 2.44 \\
\hline
\end{tabular}




\begin{tabular}{|c|c|c|}
\hline \multicolumn{3}{|c|}{$\begin{array}{l}\text { Table } 6 \\
\text { Horse Owner Responses' Listing the Main Purpose of Owning Their Horse }\end{array}$} \\
\hline Main Purpose of Horse & Frequency & Percent $\%$ \\
\hline $\begin{array}{l}\text { Recreational riding, trail riding, or } \\
\text { pleasure }\end{array}$ & 294 & 81.7 \\
\hline Therapy & 14 & 3.9 \\
\hline Participant in competition or show & 124 & 34.4 \\
\hline Racing & 10 & 2.8 \\
\hline Breeding & 34 & 9.4 \\
\hline Other & 27 & 8.1 \\
\hline Total & 503 & 140.3 \\
\hline
\end{tabular}




\begin{tabular}{|c|c|c|c|c|c|c|c|c|}
\hline \multicolumn{9}{|c|}{$\begin{array}{l}\text { Table } 7 \\
\text { Independent Sample T-Test Horse Owner Responsibilities }\end{array}$} \\
\hline \multirow{2}{*}{\multicolumn{2}{|c|}{$\begin{array}{l}\text { What was the total cost to } \\
\text { euthanize your horse? }\end{array}$}} & \multicolumn{2}{|c|}{$\frac{\text { board at }}{\text { home }}$} & 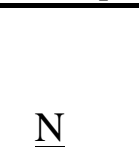 & 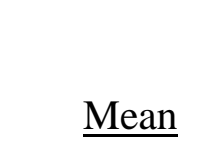 & & $\frac{\text { Std. }}{\text { Deviatio }}$ & $\frac{\text { Std. Error }}{\text { Mean }}$ \\
\hline & & \multicolumn{2}{|c|}{ No } & 33 & 627.58 & & 758.617 & 132.058 \\
\hline \multirow{2}{*}{\multicolumn{2}{|c|}{$\begin{array}{l}\text { To your knowledge what } \\
\text { is the average cost to } \\
\text { euthanize and dispose of a } \\
\text { horse }\end{array}$}} & \multicolumn{2}{|c|}{ Yes } & 144 & 362.33 & & 429.836 & 35.820 \\
\hline & & \multicolumn{2}{|c|}{ No } & 71 & $\$ 577.11$ & & 441.239 & 52.365 \\
\hline \multirow{3}{*}{\multicolumn{2}{|c|}{$\begin{array}{l}\text { What is your annual total } \\
\text { equine expenditure per } \\
\text { horse }\end{array}$}} & \multicolumn{2}{|c|}{ Yes } & 183 & $\$ 431.69$ & & 256.080 & 18.930 \\
\hline & & \multicolumn{2}{|c|}{ No } & 94 & \multicolumn{2}{|c|}{$\$ 5,910.95$} & 4196.215 & 432.807 \\
\hline & & \multicolumn{2}{|c|}{ Yes } & 212 & \multicolumn{2}{|c|}{$\$ 2,194.18$} & 2375.337 & 163.139 \\
\hline \multicolumn{9}{|c|}{ Levene's Test for Equality of Variances T-Test for Equality of Means } \\
\hline \multirow{3}{*}{$\begin{array}{l}\text { What was th } \\
\text { total cost to } \\
\text { euthanize } \\
\text { your horse }\end{array}$} & & $\underline{F}$ & Sig. & $\underline{\mathrm{t}}$ & $\underline{\mathrm{df}}$ & $\begin{array}{l}\text { Sig. (2. } \\
\text { tailed) }\end{array}$ & $\begin{array}{l}\text { (2- } \\
\text { d) } \\
\text { Difference }\end{array}$ & e $\underline{\underline{\text { Std. Error }}}$ \\
\hline & $\begin{array}{l}{ }^{e} \text { Equal } \\
\text { variances } \\
\text { assumed }\end{array}$ & 7.456 & .007 & 2.715 & 5175 & .007 & 265.249 & 97.689 \\
\hline & $\begin{array}{l}\text { Equal } \\
\text { variances } \\
\text { not assumed }\end{array}$ & & & 1.939 & 936.837 & .060 & 265.249 & 136.830 \\
\hline \multirow[t]{2}{*}{$\begin{array}{l}\text { To your } \\
\text { knowledge } \\
\text { what is the } \\
\text { average cost } \\
\text { to euthanize } \\
\text { and dispose } \\
\text { of a horse }\end{array}$} & $\begin{array}{l}\text { Equal } \\
\text { variances } \\
\text { assumed }\end{array}$ & 9.187 & .003 & 3.266 & $6 \quad 252$ & .001 & 145.424 & 44.532 \\
\hline & $\begin{array}{l}\text { Equal } \\
\text { variances } \\
\text { not assumed }\end{array}$ & & & 2.612 & 288.91 & .011 & 145.424 & 55.682 \\
\hline \multirow[t]{2}{*}{$\begin{array}{l}\text { What is your } \\
\text { annual total } \\
\text { equine } \\
\text { expenditure } \\
\text { per horse }\end{array}$} & $\begin{array}{l}\text { Equal } \\
\text { variances } \\
\text { assumed }\end{array}$ & 23.204 & .000 & 9.834 & 4304 & .000 & 3716.768 & 377.953 \\
\hline & $\begin{array}{l}\text { Equal } \\
\text { variances } \\
\text { not assumed }\end{array}$ & & & 8.036 & 5120.21 & .000 & 3716.768 & 462.532 \\
\hline
\end{tabular}




\begin{tabular}{|c|c|c|c|c|c|}
\hline $\begin{array}{l}\text { Table } 8 \\
\text { Independent Sample T } \\
\text { Area and Other Regior }\end{array}$ & $\begin{array}{l}\text { Test of Anr } \\
\text { in the Sto }\end{array}$ & al Ex & enditures $o$ & Horse Ow & rs in the Chicago \\
\hline & & & & $\frac{\text { Std. }}{\text { Deviatio }}$ & \\
\hline & Regions & $\underline{N}$ & $\underline{\text { Mean }}$ & $\underline{\mathrm{n}}$ & $\underline{\text { Std. Error Mean }}$ \\
\hline $\begin{array}{l}\text { Total number of } \\
\text { equine owned }\end{array}$ & $\begin{array}{l}\text { Other } \\
\text { regions }\end{array}$ & 246 & 5 & 6.110 & .390 \\
\hline & $\begin{array}{c}\text { Chicago } \\
\text { Area }\end{array}$ & 97 & 3 & 2.147 & .218 \\
\hline $\begin{array}{l}\text { What was the most } \\
\text { recent year you had } \\
\text { to euthanize a horse }\end{array}$ & $\begin{array}{l}\text { Other } \\
\text { regions }\end{array}$ & 155 & 2008.65 & 7.440 & .598 \\
\hline & $\begin{array}{c}\text { Chicago } \\
\text { Area }\end{array}$ & 62 & 2009.19 & 5.928 & .753 \\
\hline $\begin{array}{l}\text { What was the total } \\
\text { cost to euthanize } \\
\text { vour horse }\end{array}$ & $\begin{array}{l}\text { Other } \\
\text { regions }\end{array}$ & 123 & $\$ 334.63$ & 459.375 & 41.420 \\
\hline & $\begin{array}{c}\text { Chicago } \\
\text { Area }\end{array}$ & 52 & $\$ 595.67$ & 602.054 & 83.490 \\
\hline $\begin{array}{l}\text { To your knowledge } \\
\text { what is the average } \\
\text { cost to euthanize and }\end{array}$ & $\begin{array}{l}\text { Other } \\
\text { regions }\end{array}$ & 178 & 446.20 & 297.703 & 22.314 \\
\hline & $\begin{array}{c}\text { Chicago } \\
\text { Area }\end{array}$ & 71 & 531.69 & 365.595 & 43.388 \\
\hline $\begin{array}{l}\text { What is your annual } \\
\text { total equine } \\
\text { expenditure per } \\
\text { horse Including feed }\end{array}$ & $\begin{array}{l}\text { Other } \\
\text { regions }\end{array}$ & 215 & $\$ 2,823.37$ & 2817.003 & 192.118 \\
\hline & $\begin{array}{c}\text { Chicago } \\
\text { Area }\end{array}$ & 81 & $\$ 4,638.52$ & 4676.782 & 519.642 \\
\hline $\begin{array}{l}\text { How much did it cost } \\
\text { to relinquish or }\end{array}$ & $\begin{array}{l}\text { Other } \\
\text { regions }\end{array}$ & 28 & 26.82 & 64.509 & 12.191 \\
\hline & $\begin{array}{c}\text { Chicago } \\
\text { Area }\end{array}$ & 11 & 104.55 & 298.709 & 90.064 \\
\hline
\end{tabular}


Levene's Test for Equality of Variances T-Test for Equality of Means

\begin{tabular}{|c|c|c|c|c|c|c|c|c|}
\hline \multirow{3}{*}{$\begin{array}{l}\text { Total } \\
\text { number of } \\
\text { equine } \\
\text { owned }\end{array}$} & & $\underline{\mathrm{F}}$ & $\underline{\text { Sig. }}$ & $\underline{\mathrm{t}}$ & $\underline{\mathrm{df}}$ & $\frac{\text { Sig. }(2-}{\underline{\text { tailed })}}$ & $\underline{\text { Mean }}$ & $\frac{\text { Std. Error }}{\text { Difference }}$ \\
\hline & $\begin{array}{l}\text { Equal } \\
\text { variances } \\
\text { assumed }\end{array}$ & 13.815 & .000 & 3.230 & 341 & .001 & 2.054 & .636 \\
\hline & $\begin{array}{l}\text { Equal } \\
\text { variances } \\
\text { not } \\
\text { assumed }\end{array}$ & & & 4.601 & 337.896 & 5.000 & 2.054 & .446 \\
\hline $\begin{array}{l}\text { What was } \\
\text { the most } \\
\text { recent year } \\
\text { you had to } \\
\text { euthanize a } \\
\text { horse }\end{array}$ & $\begin{array}{l}\text { Equal } \\
\text { variances } \\
\text { assumed }\end{array}$ & 1.480 & .225 & -.512 & 215 & .609 & -.542 & 1.059 \\
\hline & $\begin{array}{l}\text { Equal } \\
\text { variances } \\
\text { not } \\
\text { assumed }\end{array}$ & & & -.564 & 140.065 & .574 & -.542 & .961 \\
\hline $\begin{array}{l}\text { What was } \\
\text { the total } \\
\text { cost to } \\
\text { euthanize }\end{array}$ & $\begin{array}{l}\text { Equal } \\
\text { variances } \\
\text { assumed }\end{array}$ & 3.298 & .071 & -3.121 & 173 & .002 & -261.039 & 83.638 \\
\hline & $\begin{array}{l}\text { Equal } \\
\text { variances } \\
\text { not } \\
\text { assumed }\end{array}$ & & & -2.801 & 77.239 & .006 & -261.039 & 93.200 \\
\hline $\begin{array}{l}\text { To your } \\
\text { knowledge } \\
\text { what is the } \\
\text { average cost } \\
\text { to euthanize } \\
\text { and dispose }\end{array}$ & $\begin{array}{l}\text { Equal } \\
\text { variances } \\
\text { assumed }\end{array}$ & .002 & .964 & -1.913 & 247 & .057 & -85.488 & 44.695 \\
\hline & $\begin{array}{l}\text { Equal } \\
\text { variances } \\
\text { not } \\
\text { assumed }\end{array}$ & & & -1.752 & 108.912 & .083 & -85.488 & 48.790 \\
\hline
\end{tabular}




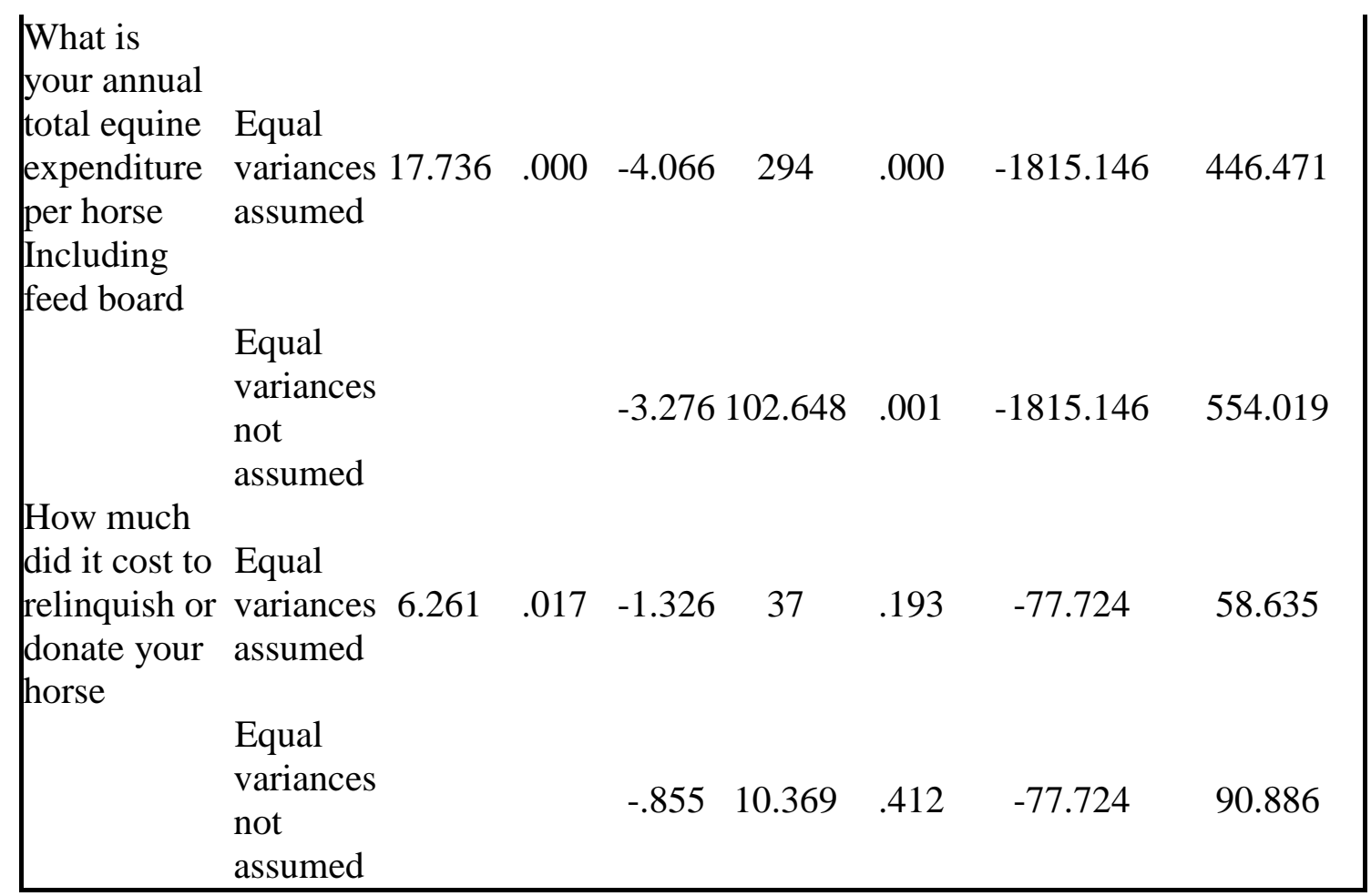




\begin{tabular}{|c|c|c|c|c|c|}
\hline $\begin{array}{l}\text { Table } 9 \\
\text { Independent Sam }\end{array}$ & Test of Total E & ine $C$ & vned an & Where They are & \\
\hline & Do you board & & & & Std. Error \\
\hline & at home & $\underline{\mathrm{N}}$ & Mean & $\underline{\text { Std. Deviation }}$ & $\overline{\text { Mean }}$ \\
\hline Total number of & $\mathrm{NO}$ & 108 & 2 & 1.582 & .152 \\
\hline & YES & 248 & 5 & 5.997 & .381 \\
\hline
\end{tabular}

\begin{tabular}{|c|c|c|c|c|c|c|c|c|}
\hline Levene': & Test for $E q$ & Iality of & Varial & $\operatorname{ces} T-T$ & est for $\mathrm{Eq}$ & ality of $N$ & eans & \\
\hline \multirow{3}{*}{$\begin{array}{l}\text { Total } \\
\text { number } \\
\text { of } \\
\text { equine } \\
\text { owned }\end{array}$} & & $F$ & Sig & $t$ & $\mathrm{df}$ & $\frac{\text { Sig. (2- }}{\text { tailed) }}$ & $\stackrel{\text { Mean }}{\text { Difference }}$ & $\frac{\text { Std. Error }}{\text { Difference }}$ \\
\hline & $\begin{array}{l}\text { Equal } \\
\text { variances } \\
\text { assumed }\end{array}$ & 24.972 & .000 & -5.550 & 354 & . 000 & -3.253 & .586 \\
\hline & $\begin{array}{l}\text { Equal } \\
\text { variances } \\
\text { not } \\
\text { assumed }\end{array}$ & & & -7.933 & 313.728 & .000 & -3.253 & .410 \\
\hline
\end{tabular}




\begin{tabular}{|c|c|c|c|c|c|}
\hline $\begin{array}{l}\text { Table } 10 \\
\text { Chi-Squc } \\
\text { Board Th } \\
\end{array}$ & $\begin{array}{l}\text { Test of the } \\
\text { ir Horse }\end{array}$ & icago Regi & Other Region & State ar & ere They \\
\hline & & & Reg & & Total \\
\hline & & & & $\underline{\text { Chicago }}$ & \\
\hline & Boardino & & Other regions & $\underline{\text { Area }}$ & \\
\hline $\begin{array}{l}\text { Boardin } \\
\text { g home }\end{array}$ & $\begin{array}{l}\text { some } \\
\text { where else }\end{array}$ & Count & 62 & 39 & 101 \\
\hline & & $\begin{array}{c}\text { Expected } \\
\text { Count }\end{array}$ & 72.4 & 28.6 & 101.0 \\
\hline & Boarding & Count & 184 & 58 & 242 \\
\hline & & $\begin{array}{c}\text { Expected } \\
\text { Count }\end{array}$ & 173.6 & 68.4 & 242.0 \\
\hline Total & & Count & 246 & 97 & 343 \\
\hline & & $\begin{array}{c}\text { Expected } \\
\text { Count }\end{array}$ & 246.0 & 97.0 & 343.0 \\
\hline
\end{tabular}

\begin{tabular}{|c|c|c|c|c|c|}
\hline \multicolumn{6}{|l|}{ Chi-Square Tests } \\
\hline & Value & $\underline{\mathrm{df}}$ & $\frac{\text { Asymp. Sig. }}{\text { (2-sided) }}$ & $\frac{\text { Exact Sig. }}{(2 \text {-sided })}$ & $\frac{\text { Exact Sig }}{\text { (1-sided) }}$ \\
\hline Pearson Chi-Square & $7.537^{\mathrm{a}}$ & 1 & .006 & \multirow{6}{*}{.008 } & \multirow{6}{*}{.005} \\
\hline Continuity Correction ${ }^{\mathrm{b}}$ & 6.832 & 1 & .009 & & \\
\hline Likelihood Ratio & 7.296 & 1 & .007 & & \\
\hline Fisher's Exact Test & & & & & \\
\hline Linear-by-Linear Association & 7.515 & 1 & \multirow[t]{2}{*}{.006 } & & \\
\hline $\mathrm{N}$ of Valid Cases & 343 & & & & \\
\hline \multicolumn{6}{|c|}{$\begin{array}{l}\text { Note. } \\
\text { a. } 0 \text { cells }(0.0 \%) \text { have expected count less than } 5 \text {. The minimum expected count is } \\
28.56 \text {. } \\
\text { b. Computed only for a } 2 \times 2 \text { table }\end{array}$} \\
\hline
\end{tabular}




\begin{tabular}{|c|c|c|c|c|c|}
\hline \multicolumn{6}{|c|}{ Responses for the Most Recent Year of Euthanizing a Horse } \\
\hline \multirow{2}{*}{\multicolumn{2}{|c|}{ Year }} & & & $\underline{\text { Valid }}$ & Cumulative \\
\hline & & Frequency & Percent \% & Percent & Percent \\
\hline & 1971 & 1 & .3 & .5 & .5 \\
\hline & 1977 & 1 & .3 & .5 & .9 \\
\hline & 1978 & 1 & .3 & .5 & 1.4 \\
\hline & 1985 & 1 & .3 & .5 & 1.8 \\
\hline & 1986 & 1 & .3 & .5 & 2.3 \\
\hline & 1987 & 1 & .3 & .5 & 2.7 \\
\hline & 1988 & 1 & .3 & .5 & 3.2 \\
\hline & 1992 & 1 & .3 & .5 & 3.6 \\
\hline & 1995 & 3 & .8 & 1.4 & 5.0 \\
\hline & 1996 & 3 & .8 & 1.4 & 6.3 \\
\hline & 1997 & 2 & .6 & .9 & 7.2 \\
\hline & 1998 & 2 & .6 & .9 & 8.1 \\
\hline & 2000 & 4 & 1.1 & 1.8 & 9.9 \\
\hline & 2001 & 2 & .6 & .9 & 10.8 \\
\hline & 2002 & 6 & 1.7 & 2.7 & 13.5 \\
\hline & 2003 & 1 & .3 & .5 & 14.0 \\
\hline & 2004 & 4 & 1.1 & 1.8 & 15.8 \\
\hline & 2005 & 11 & 3.1 & 5.0 & 20.7 \\
\hline & 2006 & 7 & 1.9 & 3.2 & 23.9 \\
\hline & 2007 & 10 & 2.8 & 4.5 & 28.4 \\
\hline & 2008 & 9 & 2.5 & 4.1 & 32.4 \\
\hline & 2009 & 9 & 2.5 & 4.1 & 36.5 \\
\hline & 2010 & 17 & 4.7 & 7.7 & 44.1 \\
\hline & 2011 & 21 & 5.8 & 9.5 & 53.6 \\
\hline & 2012 & 26 & 7.2 & 11.7 & 65.3 \\
\hline & 2013 & 23 & 6.4 & 10.4 & 75.7 \\
\hline & 2014 & 43 & 11.9 & 19.4 & 95.0 \\
\hline & 2015 & 11 & 3.1 & 5.0 & 100.0 \\
\hline & Total & 222 & 61.9 & 100.0 & \\
\hline Missing & System & 138 & 38.1 & & \\
\hline & Total & 360 & 100.0 & & \\
\hline
\end{tabular}




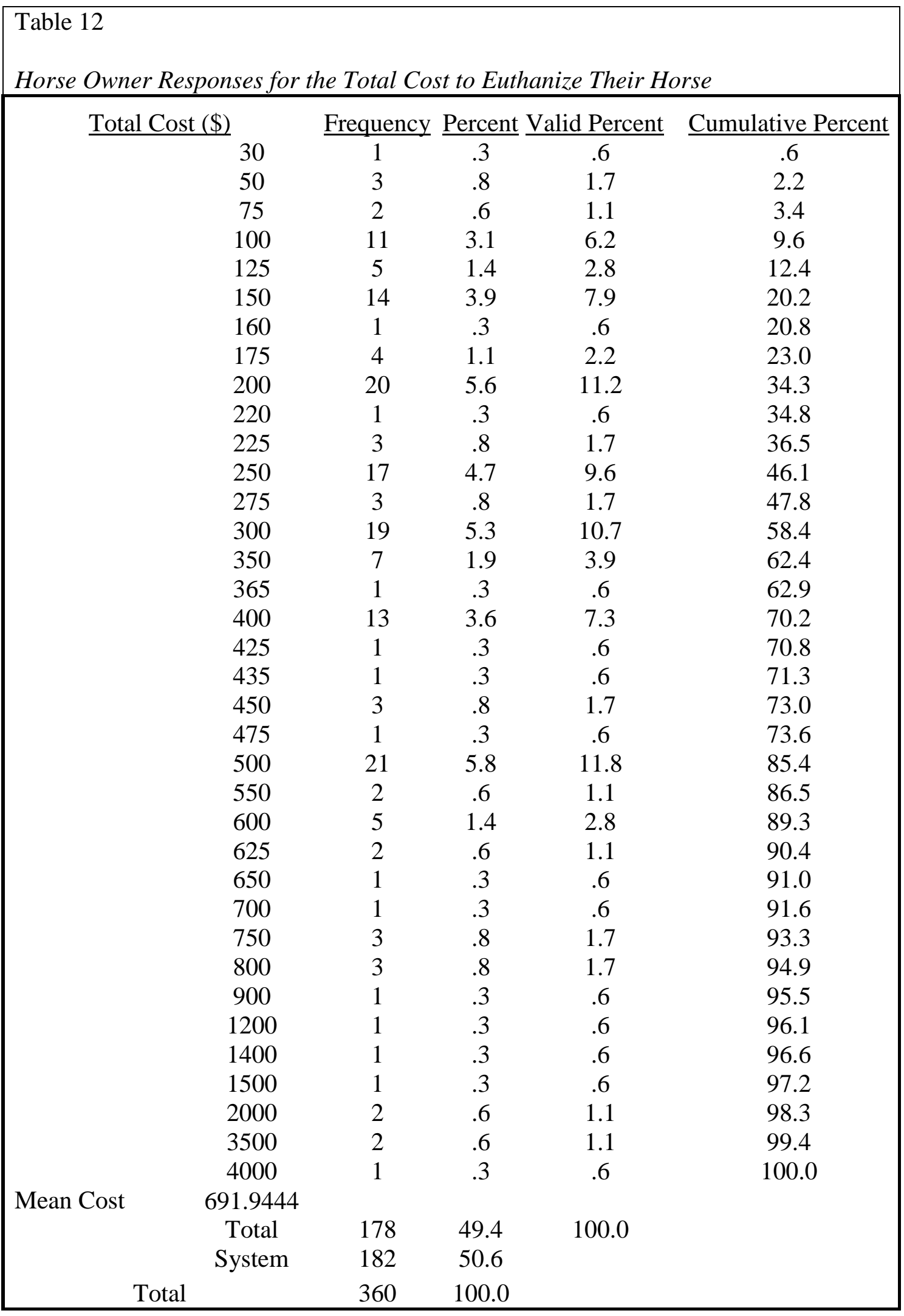




\begin{tabular}{|c|c|c|c|c|c|}
\hline \multicolumn{6}{|c|}{$\begin{array}{l}\text { Horse Owner's Knowledge of the Average Cost to Euthanize and Dispose of a Horse } \\
\text { in Illinois }\end{array}$} \\
\hline & & & Percent & $\underline{\text { Valid }}$ & \\
\hline Averag & $\operatorname{Cost}(\$)$ & Frequency & $\underline{\%}$ & Percent & Cumulative Percent \\
\hline & 99 & 1 &.$\overline{3}$ & .4 & .4 \\
\hline & 100 & 11 & 3.1 & 4.3 & 4.7 \\
\hline & 125 & 1 & .3 & .4 & 5.1 \\
\hline & 150 & 9 & 2.5 & 3.5 & 8.6 \\
\hline & 165 & 1 & .3 & .4 & 9.0 \\
\hline & 175 & 1 & .3 & .4 & 9.4 \\
\hline & 200 & 17 & 4.7 & 6.7 & 16.1 \\
\hline & 210 & 1 & .3 & .4 & 16.5 \\
\hline & 250 & 11 & 3.1 & 4.3 & 20.8 \\
\hline & 275 & 1 & .3 & .4 & 21.2 \\
\hline & 300 & 36 & 10.0 & 14.1 & 35.3 \\
\hline & 350 & 9 & 2.5 & 3.5 & 38.8 \\
\hline & 400 & 26 & 7.2 & 10.2 & 49.0 \\
\hline & 425 & 1 & .3 & .4 & 49.4 \\
\hline & 450 & 7 & 1.9 & 2.7 & 52.2 \\
\hline & 500 & 73 & 20.3 & 28.6 & 80.8 \\
\hline & 550 & 1 & .3 & .4 & 81.2 \\
\hline & 600 & 13 & 3.6 & 5.1 & 86.3 \\
\hline & 700 & 2 & .6 & .8 & 87.1 \\
\hline & 750 & 4 & 1.1 & 1.6 & 88.6 \\
\hline & 800 & 5 & 1.4 & 2.0 & 90.6 \\
\hline & 1000 & 17 & 4.7 & 6.7 & 97.3 \\
\hline & 1200 & 2 & .6 & .8 & 98.0 \\
\hline & 1500 & 2 & .6 & .8 & 98.8 \\
\hline & 2000 & 1 & .3 & .4 & 99.2 \\
\hline & 2100 & 1 & .3 & .4 & 99.6 \\
\hline & 3000 & 1 & .3 & .4 & 100.0 \\
\hline & 680.518 & & & & \\
\hline $\begin{array}{l}\text { Mean } \\
\text { Cost }\end{array}$ & & & & & \\
\hline Missing & Total & 255 & 70.8 & 100.0 & \\
\hline $\begin{array}{l}\text { Missing } \\
\text { Total }\end{array}$ & System & 105 & 29.2 & & \\
\hline Total & & 360 & 100.0 & & \\
\hline
\end{tabular}




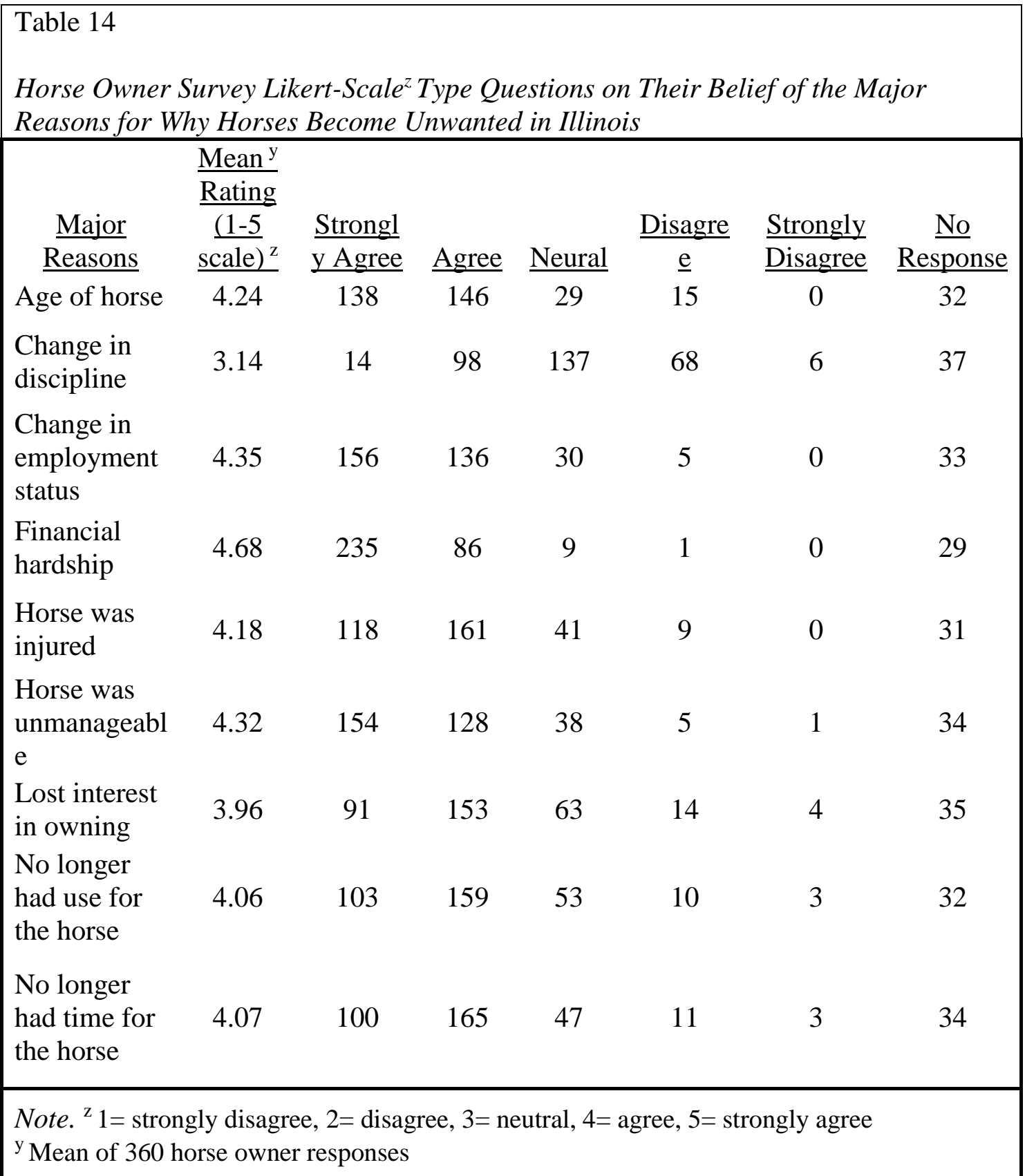




\begin{tabular}{|c|c|c|c|c|c|c|c|}
\hline $\begin{array}{l}\text { Horse Owner } \mathrm{Sl} \\
\text { Contributing } \mathrm{Fa}\end{array}$ & $\begin{array}{l}\text { irvey Lik } \\
\text { ctors to } t\end{array}$ & $\begin{array}{l}\text { ert-Scale }{ }^{z} 1 \\
\text { e Unwante }\end{array}$ & $\begin{array}{l}\text { pe Que } \\
\text { d Horse }\end{array}$ & $\begin{array}{l}\text { stions on } \\
\text { Populat }\end{array}$ & $\begin{array}{l}\text { Their Bel } \\
\text { ion }\end{array}$ & ief of the $O$ & verall \\
\hline & Mean $^{\mathrm{y}}$ & & & & & & \\
\hline & $\overline{\text { Rating }}$ & & & & & & \\
\hline & $\overline{(1-5)}$ & $\underline{\text { Strongly }}$ & & & & $\underline{\text { Strongly }}$ & $\underline{\mathrm{No}}$ \\
\hline Overall Factors & 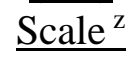 & Agree & Agree & Neutral & Disagree & Disagree & $\underline{\text { Response }}$ \\
\hline $\begin{array}{l}\text { Change in } \\
\text { breed demand }\end{array}$ & 3.10 & 23 & 75 & 149 & 72 & 8 & 33 \\
\hline $\begin{array}{l}\text { Closure of } \\
\text { processing } \\
\text { facilities }\end{array}$ & 3.98 & 146 & 90 & 51 & 24 & 18 & 31 \\
\hline $\begin{array}{l}\text { Cost to } \\
\text { maintain a } \\
\text { horse }\end{array}$ & 4.38 & 161 & 143 & 16 & 9 & 1 & 30 \\
\hline $\begin{array}{l}\text { Downturn in } \\
\text { the economy }\end{array}$ & 4.49 & 186 & 124 & 13 & 6 & 0 & 31 \\
\hline Feed prices & 4.03 & 101 & 147 & 61 & 14 & 1 & 36 \\
\hline $\begin{array}{l}\text { High Cost of } \\
\text { euthanasia and } \\
\text { disposal }\end{array}$ & 3.78 & 91 & 109 & 94 & 29 & 4 & 33 \\
\hline $\begin{array}{l}\text { Inability to sell } \\
\text { horse }\end{array}$ & 4.0 & 92 & 165 & 53 & 18 & 2 & 30 \\
\hline $\begin{array}{l}\text { Indiscriminate } \\
\text { breeding }\end{array}$ & 4.12 & 146 & 97 & 59 & 19 & 3 & 36 \\
\hline $\begin{array}{l}\text { Owner unaware } \\
\text { of what it takes } \\
\text { to own a horse }\end{array}$ & 4.34 & 158 & 139 & 25 & 8 & 1 & 29 \\
\hline $\begin{array}{l}\text { Note. }{ }^{\mathrm{z}} 1=\text { strong } \\
{ }^{\mathrm{y}} \text { Mean of } 360 \text { ho }\end{array}$ & disagr & $2=$ disag & $3=1$ & $\mathrm{al}, 4=$ & $e, 5=s$ & gly agree & \\
\hline
\end{tabular}


Table 16

Horse Owner's Knowledge of Current Methods ${ }^{y}$ to Control the Population in Illinois

\begin{tabular}{|lcc|}
\hline \multicolumn{1}{c}{ Response } & Frequency & Percent $\%$ \\
\cline { 2 - 3 } Did not respond & 277 & 76.9 \\
I don't know & 83 & 23.1 \\
Adoption facility & 199 & 55.3 \\
Donation to a university & 144 & 40.0 \\
or educational program & 205 & 56.9 \\
Euthanasia & 35 & 9.7 \\
Export & 41 & 11.4 \\
Gelding program & 48 & 13.3 \\
Horse ownership & 38 & 10.6 \\
educational programs & 122 & 33.9 \\
Horsemeat processed for & 33 & 9.9 \\
zoos & 1225 & 341 \\
Retirement facility & & \\
Other & & \\
Total & & \\
\hline Note. Question was a select all that apply & \\
\hline
\end{tabular}


Table 17

Horse Owner Survey Likert-Scale ${ }^{z}$ Type Questions of how Effective the Following Methods Can Be to Manage the Unwanted Horse Population

$\underline{\text { Mean }^{\mathrm{y}}}$

$\underline{\text { Rating }}$

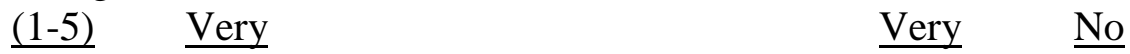

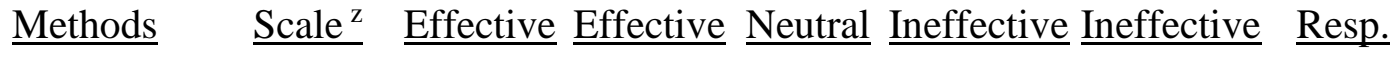

Allow horse

processing

facilities to

3.83

129

94

39

21

34

43

reopen

Create regional

euthanasia

3.55

51

123

91

30

13

52

centers

Control by

tracking the

number of

2.86

33

79

73

84

35

56

horses bred

Increase the

availability of

gelding

3.70

71

124

74

26

12

53

programs

Open more

rescue,

adoption, or

3.45

67

$97 \quad 74$

51

20

51

retirement

Reduce the cos

of euthanasia,

$4.07 \quad 104$

149

47

6

8

46

carcass disposa

Register all

horses with a

2.24

15

30

71

89

102

53

central agency

Regulate

breeders in the

2.73

42

56

65

75

74

48

state

Regulate horse

sales in the

2.19

16

24

68

90

105

57 state

Note. ${ }^{\mathrm{z}} 1=$ strongly disagree, $2=$ disagree, $3=$ neutral, $4=$ agree, $5=$ strongly agree

${ }^{\mathrm{y}}$ Mean of 360 horse owner responses 


\section{APPENDIX A}

\section{SURVEY QUESTIONNAIRE FOR HORSE OWNERS, NON-HORSE OWNERS, AND}

\section{EQUINE INDUSTRY STAKEHOLDERS IN ILLINOIS}

\section{Page 1 - Consent Form}

○ Please select if you would like to provide consent:

- I wish to take the survey and give my consent to participate in this study.

- I wish to NOT take this survey or I am NOT 18 years of age or older, and do not give my consent to participate in this study.

\section{Page 2- Demographic}

Every individual that clicks on the link, agrees to the consent, and decides to take the survey will be asked these demographic questions. These will help with classifying each individual into the three different participant categories.

- What is your gender?

- Male

- Female

- Where are you currently residing?

- Zip code

- What is your age? years

○ Please indicate the highest level of education you have completed.

- No formal education

- Some grade school

- Completed grade school

- Some high school

- Completed high school

- Some college

- Completed two-year college degree

- Completed four-year college degree

- Some graduate work

- Master's degree (for example: MA, MS, MEng, MEd, MSW, MBA)

- Professional degree (for example: MD, DDS, DVM, LLB, JD) 
- Doctorate degree (for example: $\mathrm{PhD}, \mathrm{EdD}$ ) What is your total household Income?

- Less than $\$ 25,000$

- $\$ 25,001$ to $\$ 49,999$

- $\$ 50,000$ to $\$ 99,999$

- $\$ 100,000$ to $\$ 199,999$

- Greater than $\$ 200,000$

- What is your current employment classification?

- Full time

- Part time

- Self Employed

- Unemployed

- Retired

- Other:

○ Do you currently own a horse?

- Yes

- If yes, directed to page 2 .

- No

- If no, they will be directed to the Non-Horse Owner section, page 21.

\section{Page 3 - Primary Source of Income}

- Is your primary source of income from an occupation in the Equine Industry? (example: Auction/Sale barn operator or staff, Breeder, Boarding Facility Operator, Equine Breed Association Staff, Equine Media Publisher or Editor, Equine Veterinarian, Farrier, Feed Store Owner/Manager, Manager or Owner of a Rescue or Adoption facility, Race Track Operator, State Legislator, State Agricultural and/or Veterinary Official, Barn Manager, Trainer)

- Yes

- If yes, they will be directed to the Industry Stakeholder questions, page 29.

- No.

- If no, they will be directed to the horse owner questions. Next page.

\section{Page 4 - Horse Owners}

- How many horses do you own?

- What is(are) the breed(s) and number of your horse(s)? Please state the number of horses you have next to each breed you own. If you do not have a specific breed, please put a zero in the space. 
- American Saddlebred \#

- American Quarter Horse \#

- Appaloosa \#

- Arabian and Half Arabian \#

- Crossbreed \#

- Donkey \#

- Draft \#

- Miniature Horse \#

- Morgan \#

- Mule \#

- Paint or Pinto \#

- Standardbred \#

- Tennessee Walking Horse \#

- Thoroughbred \#

- Welsh Pony and Cob \#

- Other: $\#$

- Are your horses kept on your property?

- Yes

- No (If no, they will be led to the question on page 5)

- What is the main purpose of your horse(s)? (select all that apply)

- Recreational Riding, Trail Riding or pleasure

- Therapy

- Participant in show or competitive horse events

- Racing

- Breeding

- Other, please specify:

○ Do you consider yourself a horseman/horsewoman?

- Yes

- $\quad$ No

\section{Page 5 - Horse Owner}

- If you do not keep horses on your property where do they reside?

- Boarding Facility

- Training Facility

- Friend's property 
- Relative's property

- Other, please specify:

\section{Page 6 - Horse Owner}

- How do you view equine?

- As Livestock

- As Working Animals

- As Companion Animals

- I don't have an opinion

- Are you concerned about the welfare of horses in the state of Illinois?

- Very concerned

- Somewhat concerned

- Not at all

- Are you concerned about unwanted horses in Illinois?

- Very concerned

- Somewhat concerned

- Not at all

- Before taking this survey, were you aware of the Illinois Horse Meat Act (225

ILCS 635/)? It is the law that states, "It is unlawful for any person to slaughter a horse if that person knows or should know that any of the horse meat will be used for human consumption..." For more information please go to the following http://www.ilga.gov/legislation/ilcs/ilcs3.asp?ActID $=1381 \&$ ChapterID $=24$.

- Yes

- No

- Before taking this survey, were you aware of the Public Law No: 113-76? The H.R. 3547 was passed in the $113^{\text {th }}$ Congress in January 2014. Title VII General Provisions Sec. 745 prohibits the pay of salaries or expenses of personnel at horse processing facilities in the United States. For more information please go to following https://www.congress.gov/bill/113th-congress/house-bill/3547

- Yes

- No

\section{Page 7 - Horse Owners}


- Are you personally aware of the number of neglected or abused horses in Illinois within the last 5 years?

- Yes

- No

- I don't know

- Do you believe the number of euthanized, abused, or neglected horses in Illinois within the last 5 years is:

- Increasing

- Decreasing

- No change

- I don't know

- Have you had to euthanize a horse?

- Yes (taken to page 8 questions)

- No (taken to page 9 questions)

\section{Page 8 - Horse Owners}

○ What was the most recent year you had to euthanize a horse?

- What was the total coat to euthanize your horse?

○ Please give an estimate. If there was no cost please put "none"

\section{Page 9 - Horse Owners}

- To your knowledge what is the average cost to euthanize and dispose of a horse in Illinois?

- $\$$

- What is your annual total equine expenditure per horse? (Including feed, boarding, veterinarian bills, and any other basic equine necessity costs)

- \$

- Have you ever sold a horse?

- Yes (taken to questions on page 10)

- No (taken to questions on page 11)

\section{Page 10 - Horse Owners}

If you have sold a horse, what was your reason for selling your horse? 
- Horse was too old

- Horse became injured

- Lost interest in owning the horse

- Had no use for the horse anymore

- Change in employment status

- Horse was untrainable

- Financial hardship

- To assist in an individual's horse project (4-H or FFA project)

- Sold as a training prospect

- Change in discipline or Riding Style (English, Western, Trail Riding, Reining, etc.)

- Other, please specify:

\section{Page 11 - Horse Owners}

- Have you relinquished or donated a horse to: (select all that apply)

- Rescue

- Adoption

- Retirement facility

- Organization (University, Vet School, Riding Facility)

- I have never relinquished a horse

- Other, please specify:

- If they selected any answer besides "I have never relinquished a horse" they will be taken to questions on page 12. If they selected "I have never..." they will be taken to questions on page 13.

\section{Page 12 - Horse Owners}

- If you have relinquished or donated a horse to an organization, what is the name of the organization?

- How much did it cost to relinquish or donate your horse?

- $\$$

\section{Page 13 - Horse Owners}

On a scale of strongly agree to strongly disagree, please rate if you agree the following are major reasons for why horses become unwanted in Illinois. 
Strongly Agree

Agree Neutral Disagree

Strongly

Disagree

Age of horse

C

c

c

(C)

$\mathrm{C}$

Change in discipline or riding style (English, Western, Recreational, Reining, etc.)

Change in employment status

Financial hardship

Horse was injured

C

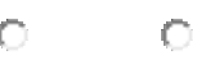

C

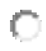

Horse was

unmanageable

Lost interest in owning

No longer had use for the horse

No longer have time for the horse

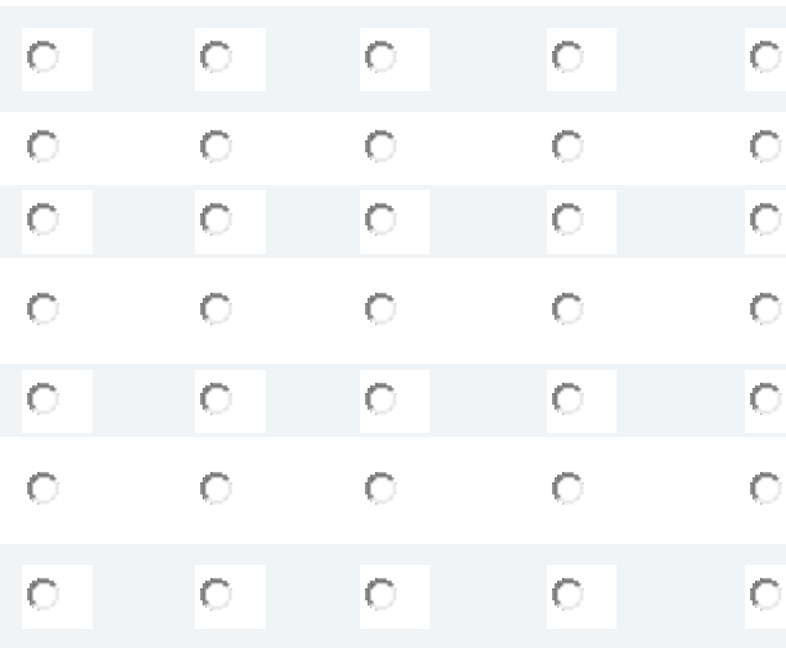

\section{Page 14 - Horse Owners}

- On a scale of strongly agree to strongly disagree, please rate if you agree the following are overall contributing factors to the unwanted horse population?

\begin{tabular}{|c|c|c|c|c|c|}
\hline & $\begin{array}{l}\text { Strongly } \\
\text { Agree }\end{array}$ & Agree & Neutral & Disagree & $\begin{array}{l}\text { Strongly } \\
\text { Disagree }\end{array}$ \\
\hline Change in breed demand & $C$ & $\mathrm{C}$ & $\mathrm{C}$ & 0 & $\mathrm{C}$ \\
\hline $\begin{array}{l}\text { Closure of processing } \\
\text { facilities in the U.S. }\end{array}$ & $C$ & $\mathrm{C}$ & $c$ & $\mathrm{C}$ & $\mathrm{C}$ \\
\hline Cost to maintain a horse & $C$ & 0 & $C$ & 0 & $C$ \\
\hline $\begin{array}{l}\text { Downturn in the } \\
\text { economy }\end{array}$ & $\mathrm{C}$ & 0 & $\mathrm{C}$ & 0 & $\mathrm{C}$ \\
\hline Feed prices & 0 & 0 & $C$ & 0 & $\mathrm{C}$ \\
\hline $\begin{array}{l}\text { High cost of euthanasia } \\
\text { and disposal }\end{array}$ & $\mathrm{C}$ & $\mathrm{C}$ & $\mathrm{C}$ & $\mathrm{C}$ & $\mathrm{C}$ \\
\hline Inability to sell horse & $\mathrm{C}$ & $\mathrm{C}$ & $\mathrm{C}$ & $\mathrm{C}$ & $C$ \\
\hline Indiscriminate breeding & $C$ & $\mathrm{C}$ & $C$ & $\mathrm{C}$ & $C$ \\
\hline
\end{tabular}


Owner unaware of what it takes to own a horse

\section{Page 15 - Horse Owners}

- To your knowledge what are the current methods in Illinois to manage the unwanted horse population: (select all that apply)

- I don't know

- Adoption Facility

- Donation to a University or Educational Program

- Euthanasia

- Gelding Program

- Horse Ownership Educational Programs

- Horsemeat processed for use in feeding zoo animals

- Retirement Facility

- Other, please specify:

\section{Page 16 - Horse Owners}

- Who do you believe has the PRIMARY responsibility for managing the unwanted horse population?

- Equine Associations

- Federal Government (USDA)

- Horse Breeders

- Horse Owners

- Humane/Animal Rights groups

- Local Government

- State Government (IL Dept. of Agriculture)

- I don't know

- Other, please specify:

\section{Page 17 - Horse Owners}

- Where are you currently getting your information on unwanted horses? (Please select all that apply)

- I don't receive information on unwanted horses

- Barn Manager

- Equine Breed Association Journal/Magazine

- Farrier 
- Horse Breeder

- Horse Trainer

- Humane/Animal Rights groups

- Printed or Online Equine Trade Publication

- Social Media (Facebook, Twitter, etc.)

- Veterinarian

- Other, please specify:

\section{Page 18 - Horse Owners}

- Do you believe the current methods of managing the unwanted horse population are:

- Very effective

- Effective

- Neutral

- Ineffective

- Very Ineffective

\section{Page 19 - Horse Owners}

- How effective can the following methods be to manage the population of unwanted horses in Illinois?

Allow horse processing
$\begin{aligned} & \text { Eery } \\ & \text { facilities to reopen in } \\ & \text { Illinois }\end{aligned}$
$\begin{aligned} & \text { Control the population } \\ & \text { by tracking the number } \\ & \text { of horses bred in Illinois }\end{aligned}$
$\begin{aligned} & \text { Create regional } \\ & \text { euthanasia centers }\end{aligned}$
$\begin{aligned} & \text { Increase the availability } \\ & \text { of gelding programs in } \\ & \text { the state }\end{aligned}$
$\begin{aligned} & \text { Open more Rescue, } \\ & \text { Adoption, or Retirement } \\ & \text { facilities }\end{aligned}$
$\begin{aligned} & \text { Reduce the costs of } \\ & \text { euthanasia, carcass } \\ & \text { disposal, or rendering }\end{aligned}$


Register all horses in the state with a central agency

Regulate breeders in the state

Regulate horse sales in the state

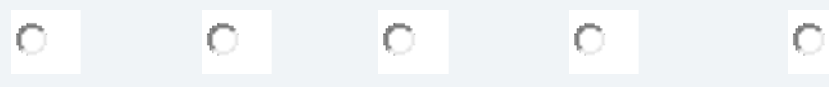

- What suggestions do you have for managing the unwanted horse population?

\section{Page 20 - Non-Horse Owners}

- Is your primary source of income from an occupation in the Equine Industry? (example: Auction/Sale barn operator or staff, Breeder, Boarding Facility Operator, Equine Breed Association Staff, Equine Media Publisher or Editor, Equine Veterinarian, Farrier, Feed Store Owner/Manager, Manager or Owner of a Rescue or Adoption facility, Race Track Operator, State Legislator, State Agricultural and/or Veterinary Official, Barn Manager, Trainer)

- Yes

- If yes, they will be directed to the Industry Stakeholder questions, page29.

- No.

- If no, they will be directed to the non-horse owner questions. Next page.

\section{Page 21 - Non-Horse Owners}

- Since you do not currently own a horse, have you ever owned a horse?

- Yes

- No

\section{Page 22 - Non-Horse Owners}

- Please select what your horse was used for:

- Recreational Riding, Trail Riding or pleasure

- Therapy

- Participant in show or competitive horse events

- Racing

- $\quad$ Breeding 
- Other, please specify:

- Why do you no longer have the horse?

- Change in employment status

- Change in discipline or riding style (English, Western, Trail Riding, Reining, etc.)

- Financial hardship

- Had no use for the horse anymore

- Horse became injured

- Horse died and was not replaced

- Horse was unmanageable

- Horse was too old and sold

- Lost interest in owning the horse

- Sold as a training prospect

- Was related to an individual's horse project (i.e. 4-H or FFA)

- Other, please specify:

\section{Page 23 - Non-Horse Owners}

- How do you view equine?

- As Livestock

- As Working Animals

- As Companion Animals

- I don't have an opinion

- Are you concerned about the welfare of horses in the state of Illinois?

- Very concerned

- Somewhat concerned

- Not at all

- Are you concerned about unwanted horses in Illinois?

- Very concerned

- Somewhat concerned

- Not at all

- Before taking this survey, were you aware of the Illinois Horse Meat Act (225 ILCS 635/)? It is the law that states, "It is unlawful for any person to slaughter a horse if that person knows or should know that any of the horse meat will be used for human consumption..." For more information please go to the following http://www.ilga.gov/legislation/ilcs/ilcs3.asp?ActID =1381\&ChapterID=24.

- Yes

- $\quad$ No 
- Before taking this survey, were you aware of the Public Law No: 113-76? The H.R. 3547 was passed in the $113^{\text {th }}$ Congress in January 2014. Title VII General Provisions Sec. 745 prohibits the pay of salaries or expenses of personnel at horse processing facilities in the United States. For more information please go to following https://www.congress.gov/bill/113th-congress/house-bill/3547

- Yes

- No

- Do you believe the number of euthanized, abused, or neglected horses in Illinois within the last 5 years is:

- Increasing

- Decreasing

- No change

- I don't know

\section{Page 24 - Non-Horse Owners}

- On a scale of strongly agree to strongly disagree, please rate if you agree the following are major reasons for why horses become unwanted in Illinois.

$\begin{aligned} & \text { Strongly } \\ & \text { Agree }\end{aligned}$
$\begin{aligned} & \text { Age of horse } \\ & \begin{array}{l}\text { Change in discipline or } \\ \text { riding style (English, }\end{array}\end{aligned}$
$\begin{aligned} & \text { Western, Recreational, } \\ & \text { Reining, etc.) } \\ & \text { Change in employment } \\ & \text { status }\end{aligned}$

Page 25 - Non-Horse Owners 
- On a scale of strongly agree to strongly disagree, please rate if you agree the following are overall contributing factors to the unwanted horse population?

\begin{tabular}{|c|c|c|c|c|c|}
\hline & $\begin{array}{c}\text { Strongly } \\
\text { Agree }\end{array}$ & Agree & Neutral & Disagree & $\begin{array}{l}\text { Strongly } \\
\text { Disagree }\end{array}$ \\
\hline Change in breed demand & 0 & c & 0 & 0 & 0 \\
\hline $\begin{array}{l}\text { Closure of processing } \\
\text { facilities in the U.S. }\end{array}$ & $c$ & 0 & 0 & 0 & 0 \\
\hline Cost to maintain a horse & 0 & 0 & 0 & 0 & 0 \\
\hline $\begin{array}{l}\text { Downturn in the } \\
\text { economy }\end{array}$ & 0 & $\mathrm{C}$ & $\mathrm{C}$ & 0 & 0 \\
\hline Feed prices & 0 & 0 & $c$ & $\mathrm{C}$ & 0 \\
\hline $\begin{array}{l}\text { High cost of euthanasia } \\
\text { and disposal }\end{array}$ & $c$ & 0 & 0 & 0 & 0 \\
\hline Inability to sell horse & 0 & 0 & 0 & 0 & 0 \\
\hline Indiscriminate breeding & 0 & 0 & 0 & 0 & 0 \\
\hline $\begin{array}{l}\text { Owner unaware of what it } \\
\text { takes to own a horse }\end{array}$ & 0 & 0 & 0 & 0 & 0 \\
\hline
\end{tabular}

\section{Page 26 - Non-Horse Owners}

- Who do you believe has the PRIMARY responsibility for managing the unwanted horse population?

- Equine Associations

- Federal Government (USDA)

- Horse Breeders

- Horse Owners

- Humane/Animal Rights groups

- Local Government

- State Government (IL Dept. of Agriculture)

- I don't know

- Other, please specify:

\section{Page 27 - Non-Horse Owners}


- Do you believe the current methods of managing the unwanted horse population are:

- Very effective

- Effective

- Neutral

- Ineffective

- Very Ineffective

\section{Page 28 - Non-Horse Owners}

- How effective can the following methods be to manage the population of unwanted horses in Illinois?

\begin{tabular}{|c|c|c|c|c|c|}
\hline & $\begin{array}{c}\text { Very } \\
\text { Effective }\end{array}$ & Effective & Neutral & Ineffective & $\begin{array}{c}\text { Very } \\
\text { Ineffective }\end{array}$ \\
\hline $\begin{array}{l}\text { Allow horse processing } \\
\text { facilities to reopen in } \\
\text { Illinois }\end{array}$ & $C$ & $C$ & $C$ & $C$ & $C$ \\
\hline $\begin{array}{l}\text { Control the population by } \\
\text { tracking the number of } \\
\text { horses bred in Illinois }\end{array}$ & 0 & 0 & 0 & $C$ & $C$ \\
\hline $\begin{array}{l}\text { Create regional } \\
\text { euthanasia centers }\end{array}$ & $C$ & $C$ & $C$ & $C$ & 0 \\
\hline $\begin{array}{l}\text { Increase the availability } \\
\text { of gelding programs in } \\
\text { the state }\end{array}$ & $C$ & $C$ & $c$ & $\mathrm{C}$ & $C$ \\
\hline $\begin{array}{l}\text { Open more Rescue, } \\
\text { Adoption, or Retirement } \\
\text { facilities }\end{array}$ & $C$ & $c$ & $c$ & $C$ & $C$ \\
\hline $\begin{array}{l}\text { Reduce the costs of } \\
\text { euthanasia, carcass } \\
\text { disposal, or rendering }\end{array}$ & $C$ & $C$ & $c$ & 0 & 0 \\
\hline $\begin{array}{l}\text { Register all horses in the } \\
\text { state with a central } \\
\text { agency }\end{array}$ & $C$ & $C$ & 0 & $C$ & $c$ \\
\hline $\begin{array}{l}\text { Regulate breeders in the } \\
\text { state }\end{array}$ & 0 & $c$ & $c$ & $C$ & $C$ \\
\hline $\begin{array}{l}\text { Regulate horse sales in } \\
\text { the state }\end{array}$ & $C$ & 0 & 0 & $C$ & $C$ \\
\hline
\end{tabular}

○ What suggestions do you have for managing the unwanted horse population? 


\section{Page 29 - Equine Industry Stakeholders}

- Please classify your occupation in the Equine Industry:

- Auction/Sale Barn operator or staff

- Barn staff or manager (barn worker, hot walker, groom, stall cleaner, etc.)

- Breeder

- Boarding or Training Facility staff, manager, or owner

- Equine Veterinarian or Vet Assistant

- Equine Breed Association staff

- Equine Media editor or staff (magazine, website, print publication etc.)

- Farrier

- Feed Store staff, manager, or owner

- Horse Trainer (any discipline)

- Race Track (operator, staff, barn worker, hot walker, stall cleaner, jockey, groom, exerciser, etc.)

- Rescue, Adoption, or Retirement facility staff, manager, or owner

- Riding Instructor

- State Agricultural or Veterinary Official

- State Legislator

- Other, please specify:

\section{Page 30 - Equine Industry Stakeholder}

- Do you work with equine on a daily basis?

- Yes

- No

- Do you own a horse?

- Yes, taken to page 33

- No, taken to page 31

- How long have you been affiliated with the equine industry?

\section{Page 31 - Equine Industry Stakeholder}

- Since you do not currently own a horse, have you ever owned a horse?

- Yes, taken to page 32

- No

\section{Page 32 - Equine Industry Stakeholder}

o Please select what your horse was used for:

- Breeding

- Participant in show or competitive event

- Racing 
- Recreational riding, Trail Riding, or for pleasure

- Therapy

- Other

- Why do you no longer have the horse?

- Change in employment status

- Change in discipline or riding style (English, Western, Trail Riding, Reining, etc.)

- Financial hardship

- Had no use for the horse anymore

- Horse became injured

- Horse died and was not replaced

- Horse was unmanageable

- Horse was too old and sold

- Lost interest in owning the horse

- Sold as a training prospect

- Was related to an individual's horse project (4-H or FFA)

- Other. Please specify:

\section{Page 33 - Equine Industry Stakeholder}

- How many horses do you own?

- What is(are) the breed(s) and number of your horse(s)? Please state the number of horses you have next to each breed you own. If you do not have a specific breed, please put a zero in the space.

- American Saddlebred \#

- American Quarter Horse \#

- Appaloosa \#

- Arabian and Half Arabian \#

- Crossbreed \#

- Donkey \#

- Draft \#

- Miniature Horse \#

- Morgan \#

- Mule \#

- Paint or Pinto \#

- Standardbred \#

- Tennessee Walking Horse \#

- Thoroughbred \#

- Welsh Pony and Cob \#

- Other: \# 
- What is the main purpose of your horse(s)? (select all that apply)

- Recreational Riding, Trail Riding or pleasure

- Therapy

- Participant in show or competitive horse events

- Racing

- Breeding

- Other, please specify:

- Are your horses kept on your property?

- Yes, taken to page 35

- No, they will be led to the question on page 34 .

\section{Page 34 - Equine Industry Stakeholders}

- If you do not keep horses on your property where do they reside?

- Boarding Facility

- Training Facility

- Friend's property

- Relative's property

- Other, please specify:

\section{Page 35 - Equine Industry Stakeholder}

- Have you had to euthanize a horse?

- Yes (taken to page 36 questions)

- No (taken to page 39 questions)

- To your knowledge what is the average cost to euthanize and dispose of a horse in Illinois?

- \$

- What is your annual total equine expenditure per horse? (Including feed, boarding, veterinarian bills, and any other basic equine necessity costs)

- $\$$

- Have you ever sold a horse?

- Yes (taken to questions on page )

- No (taken to questions on page )

- Have you relinquished or donated a horse to: (select all that apply)

- Rescue

- Adoption

- Retirement facility

- Organization (University, Vet School, Riding Facility)

- I have never relinquished a horse 
- Other, please specify:

- If they selected any answer besides "I have never relinquished a horse" they will be taken to questions on page 38. If they selected "I have never..." they will be taken to questions on page 39.

\section{Page 36 - Equine Industry Stakeholder}

- What was the most recent year you had to euthanize a horse?

○ What was the total coat to euthanize your horse?

- Please give an estimate. If there was no cost please put "none"

\section{Page 37 - Equine Industry Stakeholder}

- If you have sold a horse, what was your reason for selling your horse?

- Horse was too old

- Horse became injured

- Lost interest in owning the horse

- Had no use for the horse anymore

- Change in employment status

- Horse was untrainable

- Financial hardship

- To assist in an individual's horse project (4-H or FFA project)

- Sold as a training prospect

- Change in discipline or Riding Style (English, Western, Trail Riding, Reining, etc.)

- Other, please specify:

\section{Page 38 - Equine Industry Stakeholder}

- If you have relinquished or donated a horse to an organization, what is the name of the organization?

- How much did it cost to relinquish or donate your horse?

- $\$$

\section{Page 39 - Equine Industry Stakeholder}

○ Do you consider yourself a horseman/horsewoman?

- Yes

- No 
○ How do you view equine?

- As Livestock

- As Working Animals

- As Companion Animals

- I don't have an opinion

- Are you concerned about the welfare of horses in the state of Illinois?

- Very concerned

- Somewhat concerned

- Not at all

- Are you concerned about unwanted horses in Illinois?

- Very concerned

- Somewhat concerned

- Not at all

- Before taking this survey, were you aware of the Illinois Horse Meat Act (225 ILCS 635/)? It is the law that states, "It is unlawful for any person to slaughter a horse if that person knows or should know that any of the horse meat will be used for human consumption..." For more information please go to the following http://www.ilga.gov/legislation/ilcs/ilcs3.asp?ActID =1381\&ChapterID=24.

- Yes

- No

- Before taking this survey, were you aware of the Public Law No: 113-76? The H.R. 3547 was passed in the $113^{\text {th }}$ Congress in January 2014. Title VII General Provisions Sec. 745 prohibits the pay of salaries or expenses of personnel at horse processing facilities in the United States. For more information please go to following https://www.congress.gov/bill/113th-congress/house-bill/3547

- Yes

- No

- Are you personally aware of the number of neglected or abused horses in Illinois within the last 5 years?

- Yes

- No

- I don't know

○ Do you believe the number of euthanized, abused, or neglected horses in Illinois within the last 5 years is:

- Increasing

- Decreasing

- No change 
- I don't know

\section{Page 40 - Equine Industry Stakeholder}

- On a scale of strongly agree to strongly disagree, please rate if you agree the following are major reasons for why horses become unwanted in Illinois.

$\begin{aligned} & \text { Strongly } \\ & \text { Agree }\end{aligned}$
$\begin{aligned} & \text { Age of horse } \\ & \begin{array}{l}\text { Change in discipline or } \\ \text { riding style (English, }\end{array}\end{aligned}$
$\begin{aligned} & \text { Western, Recreational, } \\ & \text { Reining, etc.) } \\ & \text { Change in employment } \\ & \text { status }\end{aligned}$

\section{Page 41 - Equine Industry Stakeholder}

- On a scale of strongly agree to strongly disagree, please rate if you agree the following are overall contributing factors to the unwanted horse population?

\begin{tabular}{|c|c|c|c|c|c|}
\hline & $\begin{array}{l}\text { Strongly } \\
\text { Agree }\end{array}$ & Agree & Neutral & Disagree & $\begin{array}{l}\text { Strongly } \\
\text { Disagree }\end{array}$ \\
\hline Change in breed demand & $\mathrm{C}$ & $\mathrm{C}$ & $\mathrm{C}$ & $\mathrm{C}$ & $\mathrm{C}$ \\
\hline $\begin{array}{l}\text { Closure of processing } \\
\text { facilities in the U.S. }\end{array}$ & $C$ & $\mathrm{C}$ & $C$ & $\mathrm{C}$ & 0 \\
\hline Cost to maintain a horse & $\mathrm{C}$ & $\mathrm{C}$ & $\mathrm{C}$ & $\mathrm{C}$ & $C$ \\
\hline $\begin{array}{l}\text { Downturn in the } \\
\text { economy }\end{array}$ & $\mathrm{C}$ & $C$ & $C$ & $C$ & $C$ \\
\hline
\end{tabular}


Feed prices

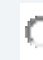

C
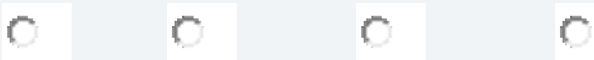

High cost of euthanasia and disposal

Inability to sell horse

Indiscriminate breeding

Owner unaware of what it

takes to own a horse

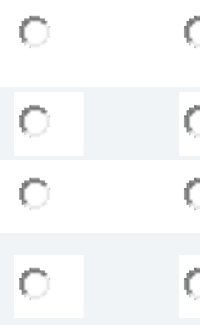

\section{C \\ $\circ$ \\ C \\ $C$}

\section{C}

C

C

$C$

c

$\mathrm{C}$

\section{Page 42 - Equine Industry Stakeholder}

- To your knowledge what are the current methods in Illinois to manage the unwanted horse population: (select all that apply)

- I don't know

- Adoption Facility

- Donation to a University or Educational Program

- Euthanasia

- Gelding Program

- Horse Ownership Educational Programs

- Horsemeat processed for use in feeding zoo animals

- Retirement Facility

- Other, please specify:

\section{Page 43- Equine Industry Stakeholder}

- Who do you believe has the PRIMARY responsibility for managing the unwanted horse population?

- Equine Associations

- Federal Government (USDA)

- Horse Breeders

- Horse Owners

- Humane/Animal Rights groups

- Local Government

- State Government (IL Dept. of Agriculture)

- I don't know

- Other, please specify:

\section{Page 44 - Equine Industry Stakeholder}

- Where are you currently getting your information on unwanted horses? (Please select all that apply)

- I don't receive information on unwanted horses 
- Barn Manager

- Equine Breed Association Journal/Magazine

- Farrier

- Horse Breeder

- Horse Trainer

- Humane/Animal Rights groups

- Printed or Online Equine Trade Publication

- Social Media (Facebook, Twitter, etc.)

- Veterinarian

- Other, please specify:

\section{Page 45 - Equine Industry Stakeholder}

- Do you believe the current methods of managing the unwanted horse population are:

- Very effective

- Effective

- Neutral

- Ineffective

- Very Ineffective

\section{Page 46 - Equine Industry Stakeholder}

- How effective can the following methods be to manage the population of unwanted horses in Illinois?

Effective
$\begin{aligned} & \text { Allow horse processing } \\ & \text { facilities to reopen in } \\ & \text { Illinois } \\ & \begin{array}{l}\text { Control the population } \\ \text { by tracking the number } \\ \text { of horses bred in Illinois }\end{array}\end{aligned}$
$\begin{aligned} & \text { Create regional } \\ & \text { euthanasia centers }\end{aligned}$


Reduce the costs of euthanasia, carcass

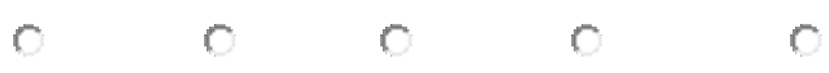

disposal, or rendering

Register all horses in the state with a central

agency

Regulate breeders in the state

Regulate horse sales in the state

$\begin{array}{lllllll}0 & 0 & 0 & 0\end{array}$

- What suggestions do you have for managing the unwanted horse population? 
APPENDIX B

ARTICLE PUBLISHED IN ILLINOIS FARM BUREAU'S FARMWEEK AND

FARMWEEKNOW.COM

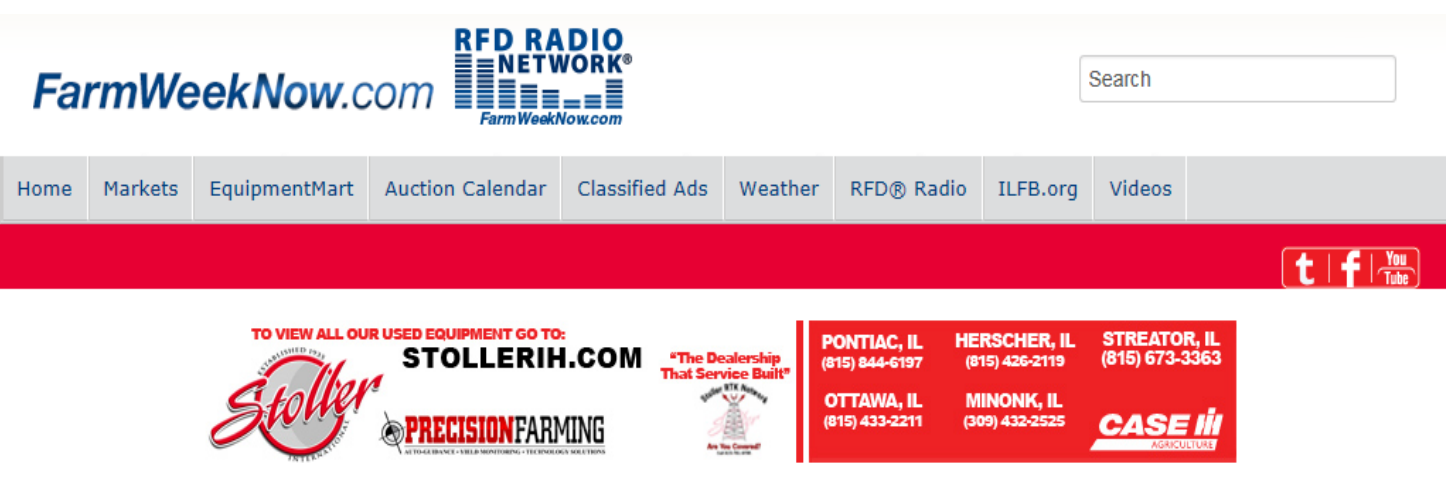

Research Examines Unwanted Horses in Illinois

Some estimates show the horse industry in Illinois to be worth $\$ 1.2$ billion annually with more than 175,000 horses in the state

Published on: Apr 14, 2015

Tweet $8+1$ Post to Your Wall. ff Like 0 Email Story D RSS Permalink torint

Some estimates show the horse industry in Illinois to be worth $\$ 1.2$ billion annually with more than 175,000 horses in the state. Still, little data exists about horse care and what happens to the animals once they may become no longer wanted.

The Illinois State University agriculture program wants Illinoisans to participate in an anonymous, Internet-based survey examining perceptions of the unwanted horse population in the state. Survey questions pertain to general knowledge of unwanted horses and, depending on if you own horses, don't own horses, or might be another equine industry stakeholder, should only take 10 minutes or so to complete.

To take the survey, click on this link, or go to: https://survey.lilt.ilstu.edu/TakeSurvey.aspx? SurveyID=UWHPSIL15.

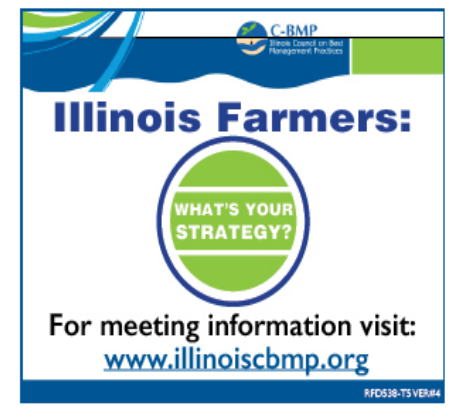

The survey will remain open for responses until Fri, May 8.

Browse the Archives

View all of our articles.

\section{Browse Story Archives}

Tweets

Follow

Farm FWN/RFD Radio @FarmWeekNow 5 Jun ^

Week Illinois poultry only, please: 
APPENDIX C

ARTICLE FOR BROWNFIELD AG NEWS FOR AMERICA

Mobile Contact Advertise

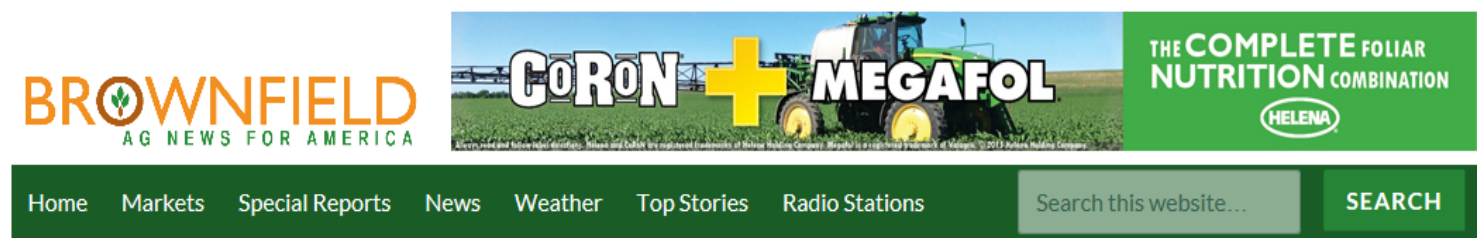

You are here: Home / Hoofbeat / What to do with unwanted horses

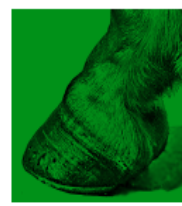

What to do with unwanted horses

Posted April 18, 2015 by Bob Meyer

Kelsey Schueler is a Master's Degree candidate in Ag Education and Leadership at Illinois State University in Normal. She is conducting an on-line survey to assess perceptions of horse owners, non-horse owners and those in the equine industry on the current methods of dealing with unwanted horses in Illinois. She talks about the effort:

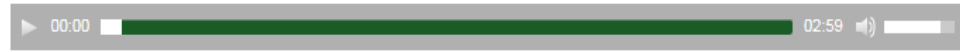

The survey is open until May $8^{\text {th }}$, Illinois residents only please. It can be taken here:

FIRST

USDA-LICENSED*

PEDv VACCINE

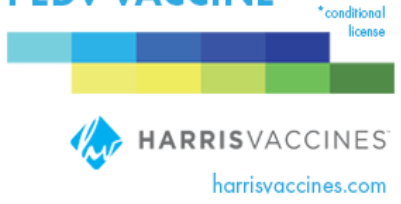

AUDIO MARKETS \& NEWS

Latest: Livestock | Commodities | Dairy

\section{FUTURES PRICES}

CROPS LIVESTOCK FINANCE ENERGY METALS

Co Zorn ZCN15 (Jul' '15) 360-4s $-3-0$ Corn ZCU15 (Sep'15) $367-4 \mathrm{~s} \quad-2-6$ Corn ZCZ15 (Dec'15) 378-0s $\quad-3-0$

Soybeans ZSN15 (Jul'15) 937-6s $\quad-8-6$ †

Soybeans ZSQ15 (Aug '15) $\quad 924-4 \mathrm{~S} \quad-10-2$ 


\section{APPENDIX D \\ NON-HORSE OWNER NON-REPORTABLE DATA \\ Participant Group 2: Non-Horse Owner}

\section{Survey Design}

Eighty-seven non-horse owner participants took the survey. The total number of non-horse owner participant population in Illinois is undefined due to the inability to track the number non-horse owners in the state of Illinois. The non-horse owner portion of the survey was open to any individual in Illinois that does not currently own a horse. The non-horse owner participants were surveyed using Select Survey. The survey included 20 to 22 questions depending on if they were previous owners. The survey consisted of seven initial demographic questions and status of horse ownership questions, one fill in the blank, one check all that apply, seven Likert scale, three yes or no, and three multiple choice questions. If the individual previously owned a horse they were asked why they no longer have the animal. Each participant was then asked their view point on equine, if they are concerned with horse welfare and unwanted horses in Illinois, their knowledge of state and national laws, what they believe the number of unwanted horses is doing, who has the primary responsibility to manage the population, and how effective the current methods are to maintain the population. They were then asked to rate the major reasons for why horses become unwanted, overall contributing factors to the population, and how effective different methods would be to manage the unwanted 
population in Illinois. Finally, they were asked for their suggestions to managing the unwanted horse population.

\section{Administration of the Survey}

The survey was administered through email communication and was advertised through an article in FarmWeek, FarmWeekNow.com, and a radio interview and article with Brownfield Ag News. All participants were guided to follow a link to participate in the online survey. The email from the Horsemen's Council of Illinois was sent on 8 April 2015. The article in FarmWeek and FarmWeekNow.com was published 14 April 2015. The radio interview and web article was published 18 April 2015 on Brownfield Ag News website. The survey was closed 15 May 2015.

\section{Data Collection}

Data was collected via Select Survey. Descriptive statistics were run on Likert-scale questions, open-ended numeric questions, and quantitative data. Qualitative responses were used to support quantitative data. In SPSS, the data was analyzed and interpreted using descriptive statistics (mean, median, mode, frequency, and range).

\section{Non-reportable Data and Discussion}

Demographics. Sixty-nine percent of the non-horse owner respondents were female and the remaining thirty percent were male. The average age of respondents was 42 years old. The top highest reported levels of education were completed four-year college degree $(26.4 \%)$, some college (17.2\%), completed two-year college degree $(12.6 \%)$ and some graduate work (12.6\%). Eighty-one percent of respondents had an average income ranging from $\$ 25,001-199,999$. 
Horse Ownership. Of the survey respondents forty-eight percent have owned a horse before, but do not currently own a horse. Of the forty-eight percent, the major purpose of their horse was for recreation, trail riding, or pleasure (39\%). Non-horse owners who have owned a horse before were asked why they no longer have the animal, 13\% stated they no longer owned the horse for "other" reasons, $12 \%$ responded horse died and was not replaced, and 10\% lost interest in owning the horse. The "other" open-ended responses included, "graduated college and easier to relocate without her", "health issues", "moved away from farm", and "went back to school and no longer had the time/money to ride and compete".

Perceptions of Equine and Unwanted Horses in Illinois. The majority (70\%) of non-horse owners responded that they believed the number of horses euthanized, abused, or neglected in Illinois is increasing. Non-horse owner respondents rated their concern with the welfare of horses and horses becoming unwanted in Illinois on a five-point Likert-type scale ( $1=$ not at all, $2=$ somewhat concerned, $3=$ very concerned $)$. Non-horse owners rated their concern of the welfare of horses with a mean of 2.26 and horses becoming unwanted with a mean of 2.39. They were also asked about their awareness of current laws in Illinois and in the United States about the processing of horses. $71 \%$ of non-horse owners were aware of the Illinois Horsemeat Act before taking this survey. Whereas only 29\% of respondents reported they were aware of the Public Law No 11376 that prohibits the pay of salaries or expenses of personnel at horse processing facilities in the U.S. The majority (40.2\%) of non-horse owners responded that horse owners have the primary responsibility to manage the unwanted horse population (Table 1). 
Major Reasons for why Horses Become Unwanted. Non-horse owner participants rated the major reasons for why horses become unwanted in Illinois on a five-point scale $(1=$ strongly disagree, $2=$ disagree, $3=$ neutral, $4=$ agree, $5=$ strongly agree $)$. Non-horse owners rated financial hardship (4.56) the highest, the age of horse (4.12) second, and horse became injured (4.04) third (Table 2).

\section{Overall Contributing Factors to the Unwanted Horse Population. Survey} respondents rated the overall contributing factors to the unwanted horse population on a five-point Likert-type scale ( $1=$ strongly disagree, $2=$ disagree, $3=$ neutral, $4=$ agree, $5=$ strongly agree). Non-horse owners ranked (mean): cost to maintain a horse (4.5), downturn in the economy (4.32), and owner unaware of what it takes to care for a horse (4.22) as the top three reasons (Table 3).

\section{Perceptions of Effective Methods to Manage the Unwanted Horse Population.}

Respondents rated the current methods to maintain the unwanted horse population on a five-point scale $(1=$ very ineffective, $2=$ ineffective, $3=$ neutral, $4=$ effective, $5=$ very effective). They rated the current methods with a mean score of 2.07 (Table 4) Non-horse owner participants rated the how effective the following reasons could be to help maintain the unwanted horse population on a five-point scale $(1=$ very ineffective, $2=$ ineffective, $3=$ neutral, $4=$ effective, $5=$ very effective). Non-horse owners ranked (mean); reduce cost of euthanasia, carcass disposal, or rendering (3.93), allow horse processing facilities to reopen (3.87), and open more rescue, adoption, or retirement facilities (3.58) (Table 5).

Suggestions. Non-horse owners were asked through an open-ended question about any suggestions they have for managing the unwanted horse population and responses 
included: allow for slaughtering, make the groups that campaigned against slaughter figure it out, don't breed so many horses and educate people before buying, reopen processing facilities.

\begin{tabular}{|c|c|c|c|c|}
\hline $\begin{array}{l}\text { Non-Horse Owner Responses to who } \\
\text { Manage the Unwanted Horse Populat }\end{array}$ & y Believe & s the Pri & ary Rest & nsibility to \\
\hline & Frequenc & & $\underline{\text { Valid }}$ & Cumulative \\
\hline & $\mathrm{y}$ & $\underline{\text { Percent }}$ & Percent & $\underline{\text { Percent }}$ \\
\hline Did not answer & 20 & 23.0 & 23.0 & 23.0 \\
\hline Federal Government (USDA) & 7 & 8.0 & 8.0 & 31.0 \\
\hline Horse Breeders & 3 & 3.4 & 3.4 & 34.5 \\
\hline Horse Owners & 35 & 40.2 & 40.2 & 74.7 \\
\hline Humane/Animal Right groups & 5 & 5.7 & 5.7 & 80.5 \\
\hline I don't know & 7 & 8.0 & 8.0 & 88.5 \\
\hline $\begin{array}{l}\text { State Government (IL Dept. of } \\
\text { Agriculture) }\end{array}$ & 10 & 11.5 & 11.5 & 100.0 \\
\hline Total & 87 & 100.0 & 100.0 & \\
\hline
\end{tabular}

Table 2

Non-Horse Owner Responses for Major Reasons for why Horses Become Unwanted

Mean

rating Strongly

scale $\underline{\text { Agree }}$ Agree Neutral Disagree Disagree Response

Age of Horse

$4.12 \quad 31 \quad 29 \quad 5$

7

73

Change in

Discipline

2.49

1

5

32

26

9

73

Change in

Employment

$4.00 \quad 16$

43

12

2

0

73

Status

Financial

Hardship

4.5

Horse was

Injured

$4.04 \quad 23 \quad 33$

14

$\begin{array}{llll}3.78 & 18 & 32 & 10\end{array}$

12

$\begin{array}{lll}3.75 & 15 & 38\end{array}$

9

9

73

Note. Table continued on to next page. 
No longer had use for the horse

3.59

12

28

19

11

0

70

No longer had

time for the

3.99

18

40

11

4

0

73

horse

Table 3

Non-Horse Owner Responses for What They Believe are the Overall Contributing

Factors to the Unwanted Horse Population

\begin{tabular}{|c|c|c|c|c|c|c|c|}
\hline & $\frac{\underline{\text { Mean }}}{\underline{\text { rating }}}$ & $\frac{\text { Strongly }}{\underline{\text { Agree }}}$ & $\frac{\text { Agre }}{\underline{\mathrm{e}}}$ & $\underline{\text { Neutral }}$ & $\underline{\text { Disagree }}$ & $\frac{\text { Strongly }}{\underline{\text { Disagree }}}$ & $\underline{\underline{\text { Total }}}$ \\
\hline $\begin{array}{l}\text { Change in Breed } \\
\text { Demand }\end{array}$ & 2.80 & 2 & 12 & 32 & 21 & 5 & 72.0 \\
\hline $\begin{array}{l}\text { Closure of } \\
\text { processing } \\
\text { facilities }\end{array}$ & 3.64 & 21 & 21 & 13 & 12 & 3 & 70.0 \\
\hline $\begin{array}{l}\text { Cost to maintain } \\
\text { a horse }\end{array}$ & 4.5 & 40 & 29 & 2 & 1 & 0 & 72.0 \\
\hline $\begin{array}{l}\text { Downturn in the } \\
\text { Economy }\end{array}$ & 4.32 & 35 & 27 & 8 & 2 & 0 & 72.0 \\
\hline Feed Prices & 4.10 & 24 & 36 & 8 & 3 & 1 & 72.0 \\
\hline $\begin{array}{l}\text { High Cost of } \\
\text { Euthanasia and } \\
\text { disposal }\end{array}$ & 3.97 & 23 & 26 & 17 & 4 & 0 & 70.0 \\
\hline $\begin{array}{l}\text { Inability to sell } \\
\text { horse }\end{array}$ & 4.10 & 22 & 36 & 11 & 2 & 0 & 71.0 \\
\hline $\begin{array}{l}\text { Indiscriminate } \\
\text { Breeding }\end{array}$ & 3.32 & 13 & 16 & 24 & 17 & 1 & 71.0 \\
\hline $\begin{array}{l}\text { Owner unaware } \\
\text { of what it takes } \\
\text { to own a horse }\end{array}$ & 4.22 & 32 & 28 & 8 & 4 & 0 & 72.0 \\
\hline
\end{tabular}

Table 4

Non-Horse Owner Responses of Perceptions of the Current Methods to Manage the Unwanted Horse Population.

\begin{tabular}{|c|c|c|c|c|}
\hline & $\frac{\text { Frequenc }}{\mathrm{y}}$ & Percent & $\frac{\text { Valid }}{\text { Percent }}$ & $\frac{\text { Cumulative }}{\text { Percent }}$ \\
\hline Did not respond & 15 & 17.2 & 17.2 & 17.2 \\
\hline Very Effective & 0 & 0.0 & 0.0 & 0.0 \\
\hline Effective & 1 & 1.1 & 1.1 & 18.4 \\
\hline
\end{tabular}




$\begin{array}{lcccc}\text { Neutral } & 18 & 20.7 & 20.7 & 82.8 \\ \text { Ineffective } & 38 & 43.7 & 43.7 & 62.1 \\ \text { Very Ineffective } & 15 & 17.2 & 17.2 & 100.0 \\ \text { Total } & 87 & 100.0 & 100.0 & \end{array}$

Table 5

Non-Horse Owner Response of how Effective the Following Methods be to Managing the Unwanted Horse Population

\begin{tabular}{|c|c|c|c|c|c|c|c|}
\hline & $\frac{\frac{\text { Mean }}{\text { rating }}}{\underline{\text { scale }}}$ & $\underline{\text { Very }}$ & Effective & $\underline{\text { Neutral }}$ & $\frac{\text { Ineffectiv }}{\underline{\mathrm{e}}}$ & $\frac{\frac{\text { Very }}{\text { Ineffectiv }}}{\underline{\mathrm{e}}}$ & $\underline{\text { Total }}$ \\
\hline $\begin{array}{l}\text { Allow horse } \\
\text { processing } \\
\text { facilities to } \\
\text { reopen }\end{array}$ & 3.87 & 30 & 18 & 10 & 4 & 7 & 69.0 \\
\hline $\begin{array}{l}\text { Create } \\
\text { regional } \\
\text { euthanasia } \\
\text { centers }\end{array}$ & 3.51 & 8 & 33 & 18 & 6 & 4 & 69.0 \\
\hline $\begin{array}{l}\text { Control by } \\
\text { tracking the } \\
\text { number of } \\
\text { horses bred }\end{array}$ & 3.33 & 10 & 20 & 23 & 12 & 2 & 67.0 \\
\hline $\begin{array}{l}\text { Increase the } \\
\text { availability } \\
\text { of gelding } \\
\text { programs }\end{array}$ & 3.5 & 9 & 25 & 27 & 5 & 2 & 68.0 \\
\hline $\begin{array}{l}\text { Open more } \\
\text { rescue, } \\
\text { adoption, or } \\
\text { retirement }\end{array}$ & 3.58 & 14 & 29 & 12 & 11 & 3 & 69.0 \\
\hline $\begin{array}{l}\text { Reduce the } \\
\text { cost of } \\
\text { euthanasia, } \\
\text { carcass } \\
\text { disposal }\end{array}$ & 3.93 & 18 & 35 & 10 & 5 & 1 & 69.0 \\
\hline $\begin{array}{l}\text { Register all } \\
\text { horses with a } \\
\text { central } \\
\text { agency }\end{array}$ & 3.24 & 13 & 15 & 20 & 15 & 5 & 68.0 \\
\hline $\begin{array}{l}\text { Regulate } \\
\text { breeders in } \\
\text { the state }\end{array}$ & 3.30 & 14 & 19 & 16 & 14 & 6 & 69.0 \\
\hline $\begin{array}{l}\text { Regulate } \\
\text { horse sales in } \\
\text { the state }\end{array}$ & 3.16 & 9 & 18 & 21 & 13 & 6 & 67 \\
\hline
\end{tabular}




\section{APPENDIX E \\ EQUINE INDUSTRY STAKEHOLDER NON-REPORTABLE DATA \\ Participant Group 3: Equine Industry Stakeholder}

\section{Survey Design}

Equine Industry Stakeholder Participant and Survey Design. There were total number thirty-nine equine industry stakeholders who participated in the survey. The survey included 35-44 questions depending on status of horse ownership. The industry stakeholder portion consisted of seven initial demographic and status of horse ownership questions, nine fill in the blank, six check all that apply, seven Likert scale, nine yes or no, and six multiple choice questions. Industry stakeholders were asked what their occupation is in the industry, if they work with horses on a daily basis, if they currently or have ever owned a horse and what the animals purpose was. If current horse ownership was determined they were asked how many, what breed, and where they are housed. Stakeholders who currently own or have owned horses were asked if they have ever euthanized, sold, or relinquished a horse, what the reasoning was and total cost. All were asked if they considered themselves a horsemen, how they view equine, if they are concerned with the welfare and unwanted horses in Illinois, current knowledge of state and national laws, if they are personally aware of unwanted horses, what they believe the current number of unwanted horses is doing, their knowledge of current methods to 
maintain the population, who has the primary responsibility, where they are getting their current information on unwanted horses, and how effective the current methods are to maintaining the population. They were asked to rank the major reasons for why horses become unwanted, the overall contributing factors, and possible solutions for managing the population in Illinois. . Finally, they were asked to give their suggestions for managing the unwanted horse population.

\section{Survey Administration}

The survey was administered through email communication and was advertised through an article in FarmWeek, FarmWeekNow.com, and a radio interview and article with Brownfield Ag News. All participants were guided to follow a link to participate in the online survey. The email from the Horsemen's Council of Illinois was sent on 8 April 2015. The article in FarmWeek and FarmWeekNow.com was published 14 April 2015. The radio interview and web article was published 18 April 2015 on Brownfield Ag News website. The survey was closed 15 May 2015

\section{Data Collection}

Data was collected via Select Survey. Descriptive statistics were run on Likert-scale questions, open-ended numeric questions, and quantitative data. Qualitative responses were used to support quantitative data. In SPSS, the data was analyzed and interpreted using descriptive statistics (mean, median, mode, frequency, and range).

\section{Non-reportable Data and Discussion}

Demographics. Eighty-seven percent of the equine industry stakeholder respondents were female. The average age of respondents was 49 years old. The highest reported level of education was some college (30.77\%), completed 4-year college degree $(23.1 \%)$, 
completed two-year college degree (15.38\%) and some graduate work (12.6\%). Eightyfive percent of respondents had an average income ranging from $\$ 25,001-199,999$. Equine industry stakeholders were asked their primary occupation in the industry. The top three responses were; boarding or training facility staff, manager, or owner (27.9\%), riding instructor $(9.3 \%)$, and equine veterinarian or veterinarian assistant $(9.3 \%)$.

Horse Ownership. Of the Illinois equine industry stakeholders, five of the thirty-nine respondents did not currently own a horse, whereas the remaining thirty-four respondents owned an average of 11.36 horses. There was a total of 419 total equine and 411 horses represented. Of those equine the most prevalent breeds were the American Quarter Horse (30.55\%), cross-bred (13.13\%), and other (13.13\%). The equine industry stakeholders that own horses reported a total annual equine expenditure (includes feed, boarding, veterinarian bills, and any other necessity costs) at a minimum of $\$ 300$ to a maximum of $\$ 15,000$, with an average cost of $\$ 3,316$ spent annually.

Major Reasons for why Horses Become Unwanted. Equine industry stakeholder participants rated the major reasons for why horses become unwanted in Illinois on a five-point scale $(1=$ strongly disagree, $2=$ disagree, $3=$ neutral, $4=$ agree, $5=$ strongly agree). Illinois equine industry stakeholders rated financial hardship (4.33) the highest, the age of horse (4.24) second, and horse became injured (4.15) third (Table 2).

\section{Overall Contributing Factors to the Unwanted Horse Population. Survey} respondents rated the overall contributing factors to the unwanted horse population on a five-point Likert-type scale ( $1=$ strongly disagree, $2=$ disagree, $3=$ neutral, $4=$ agree, $5=$ strongly agree). Illinois equine industry stakeholders ranked (mean): feed prices (4.44), 
cost to maintain a horse (4.26), and downturn in the economy (4.15), as the top three reasons (Table 3).

\section{Perceptions of Effective Methods to Manage the Unwanted Horse Population.}

Respondents rated the current methods to maintain the unwanted horse population on a three-point scale $(1=$ ineffective, $2=$ neutral, $3=$ effective $)$ with a mean of 2.0 (Table 5$)$. Participants were asked who has the primary responsibility to manage the unwanted horse population. Horse owners were ranked the highest at $42 \%$ and the state government second at $9.3 \%$ (Table 4). They rated the current methods with a mean score of 2.0 (Table 4). Equine industry stakeholder participants rated the how effective the following reasons could be to help maintain the unwanted horse population on a five-point scale $(1=$ very ineffective, $2=$ ineffective, $3=$ neutral, $4=$ effective, $5=$ very effective $)$. Non-horse owners ranked (mean); allow horse processing facilities to reopen (4.28), reduce cost of euthanasia, carcass disposal, or rendering (3.89), and create regional euthanasia (3.68) (Table 6).

\section{Limitations}

The equine industry stakeholder portion of the survey had multiple problems such as, numerous questions not appearing for participants to answer causing incorrect collection of the entire group's data and an inadequate response rate causing the data to not be a good representation of the industry population. 
Table 1

Equine Industry Stakeholder Occupations

Did not respond

Frequency Percent $\underline{\text { Percent }} \underline{\text { Percent }}$

Barn staff or manager (barn worker,

hot walker, groom, stall cleaner, etc.)

Boarding or Training Facility staff, manager, or owner

Boarding/training/riding instructor -

facility owner

Breeder

Carriage Owner / operator

Equine Media editor or staff

(magazine, website, print publication

etc.)

Equine Program Director at residential

facility for boys

Equine Veterinarian or Vet Assistant

Farrier

Horse Trainer (any discipline)

Illinois Thoroughbred Horsemen's

Association, Inc.

$\begin{array}{llll}3 & 7.0 & 7.0 & 7.0\end{array}$

$\begin{array}{llll}4 & 9.3 & 9.3 & 16.3\end{array}$

$\begin{array}{llll}12 & 27.9 & 27.9 & 44.2\end{array}$

Pres/ coo of therapeutic riding

program

Racing

Rescue, Adoption, or Retirement

facility staff, manager, or owner

retired equine science educator

Riding Instructor

Trucker

Total

2.3

2.3

46.5

2

4.7

4.7

51.2

1

2.3

2.3

53.5

$\begin{array}{lll}2.3 & 2.3 & 55.8\end{array}$

2.3

55.8

$\begin{array}{lll}2.3 & 2.3 & 58.1\end{array}$

$\begin{array}{llll}4 & 9.3 & 9.3 & 67.4\end{array}$

$\begin{array}{llll}1 & 2.3 & 2.3 & 69.8\end{array}$

$\begin{array}{llll}3 & 7.0 & 7.0 & 76.7\end{array}$

1

2.3

2.3

79.1

$\begin{array}{lll}2.3 & 2.3 & 81.4\end{array}$

$\begin{array}{lllll}1 & 2.3 & 2.3 & 83.7\end{array}$

2.3

2.3

86.0

$\begin{array}{lll}2.3 & 2.3 & 88.4\end{array}$

$\begin{array}{llll}4 & 9.3 & 9.3 & 97.7\end{array}$

1

2.3

2.3

100.0

Table 2

Equine Industry Stakeholder Responses for Major Reasons why Horses Become Unwanted

\begin{tabular}{|c|c|c|c|c|c|c|c|}
\hline & $\begin{array}{l}\text { Mean } \\
\text { rating } \\
\text { scale }\end{array}$ & $\begin{array}{c}\text { Strongly } \\
\text { Agree }\end{array}$ & Agree & Neutral & Disagree & $\begin{array}{l}\text { Strongly } \\
\text { Disagree }\end{array}$ & $\begin{array}{l}\text { Total } \\
\text { Resp. }\end{array}$ \\
\hline Age of Horse & 4.24 & 7 & 22 & 7 & 2 & 1 & 39 \\
\hline
\end{tabular}




\begin{tabular}{llllllll|}
$\begin{array}{l}\text { Change in } \\
\text { Discipline } \\
\text { Change in }\end{array}$ & 3.82 & 7 & 22 & 7 & 2 & 1 & 39 \\
$\begin{array}{l}\text { Employment } \\
\text { Status } \\
\text { Financial }\end{array}$ & 2.95 & 1 & 11 & 16 & 7 & 4 & 39 \\
$\begin{array}{l}\text { Hardship } \\
\text { Horse was }\end{array}$ & 4.0 & 10 & 22 & 5 & 1 & 1 & 39 \\
$\begin{array}{l}\text { Injured } \\
\text { Horse was } \\
\text { unmanageable }\end{array}$ & 4.10 & 15 & 17 & 4 & 2 & 1 & 39 \\
$\begin{array}{l}\text { Lost interest } \\
\text { in Owning }\end{array}$ & 4.15 & 14 & 20 & 3 & 1 & 1 & 39 \\
$\begin{array}{l}\text { No longer } \\
\text { had use for } \\
\text { the horse }\end{array}$ & 3.87 & 11 & 17 & 7 & 3 & 1 & 39 \\
$\begin{array}{l}\text { No longer } \\
\text { had time for } \\
\text { the horse }\end{array}$ & 3.84 & 7 & 23 & 6 & 2 & 1 & 39 \\
\hline
\end{tabular}

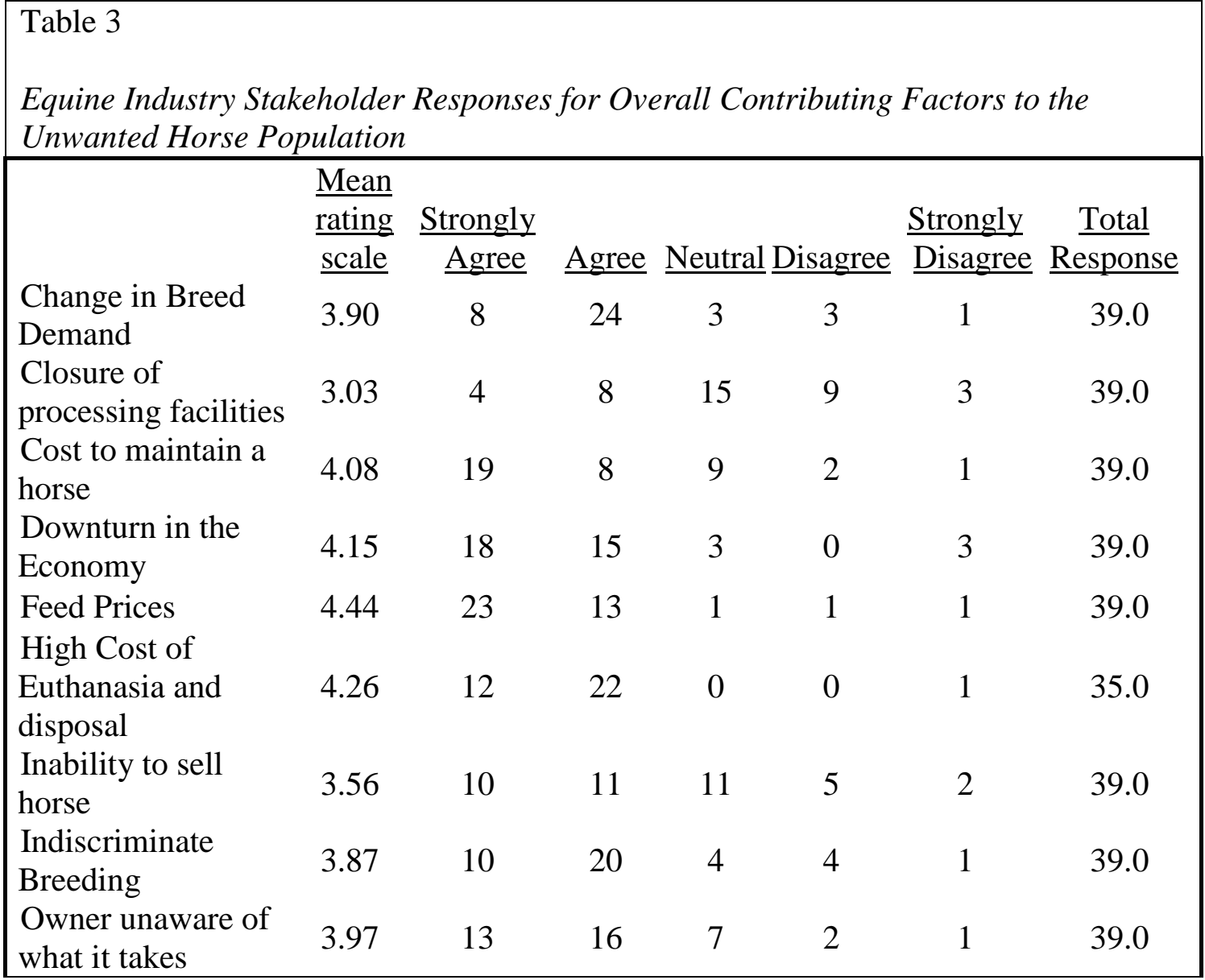


Table 4

Equine Industry Stakeholder Responses for who has the Primary Responsibility to Maintain the Unwanted Horse Population

\begin{tabular}{|c|c|c|c|c|}
\hline & & $\underline{\text { Percen }}$ & $\underline{\text { Valid }}$ & \\
\hline & Frequency & $\underline{\mathrm{t}}$ & $\underline{\text { Percent }}$ & $\underline{\text { Cumulative Percent }}$ \\
\hline Did not Answer & 4 & 9.3 & 9.3 & 9.3 \\
\hline Equine Associations & 3 & 7.0 & 7.0 & 16.3 \\
\hline $\begin{array}{l}\text { Federal Government } \\
\text { (USDA) }\end{array}$ & 3 & 7.0 & 7.0 & 23.3 \\
\hline Horse Breeders & 2 & 4.7 & 4.7 & 27.9 \\
\hline Horse Owners & 18 & 41.9 & 41.9 & 69.8 \\
\hline $\begin{array}{l}\text { Humane/Animal Right } \\
\text { groups }\end{array}$ & 2 & 4.7 & 4.7 & 74.4 \\
\hline I don't know & 4 & 9.3 & 9.3 & 83.7 \\
\hline $\begin{array}{l}\text { Maybe a combination of } \\
\text { the above }\end{array}$ & 1 & 2.3 & 2.3 & 86.0 \\
\hline $\begin{array}{l}\text { Owners, Breeders, } \\
\text { Federal, State, and Local } \\
\text { Government }\end{array}$ & 1 & 2.3 & 2.3 & 88.4 \\
\hline $\begin{array}{l}\text { State Government (IL } \\
\text { Dept. of Agriculture) }\end{array}$ & 4 & 9.3 & 9.3 & 97.7 \\
\hline Total & 43 & 100.0 & 100.0 & \\
\hline
\end{tabular}

\section{Table 5}

Equine Industry Stakeholder Responses for the Current Effectiveness of Methods to Maintain the Unwanted Horse Population

\begin{tabular}{|lcccc|}
\hline & Frequency & Percent & Valid Percent & Cumulative Percent \\
No Response & 4 & 9.3 & 9.3 & 9.3 \\
Ineffective & 13 & 30.2 & 30.2 & 39.5 \\
Neutral & 13 & 30.2 & 30.2 & 69.8 \\
Affective & 13 & 30.2 & 30.2 & 100.0 \\
Total & 43 & 100.0 & 100.0 & \\
\hline
\end{tabular}

Table 6

Equine Industry Stakeholder Responses for how Effective the Following Methods Could be to Maintain the Unwanted Horse Population

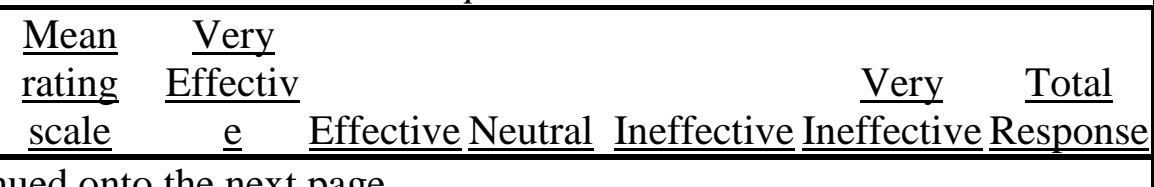

Note. Table continued onto the next page. 


\begin{tabular}{|c|c|c|c|c|c|c|c|}
\hline $\begin{array}{l}\text { Allow horse } \\
\text { processing } \\
\text { facilities to } \\
\text { reopen }\end{array}$ & 4.26 & 24 & 7 & 7 & 0 & 2 & 40.0 \\
\hline $\begin{array}{l}\text { Create regional } \\
\text { euthanasia } \\
\text { centers }\end{array}$ & 3.68 & 10 & 12 & 10 & 6 & 0 & 38.0 \\
\hline $\begin{array}{l}\text { Control by } \\
\text { tracking the } \\
\text { number of } \\
\text { horses bred }\end{array}$ & 3.05 & 5 & 9 & 11 & 9 & 4 & 38.0 \\
\hline $\begin{array}{l}\text { Increase the } \\
\text { availability of } \\
\text { gelding } \\
\text { programs }\end{array}$ & 3.57 & 4 & 21 & 5 & 6 & 1 & 37.0 \\
\hline $\begin{array}{l}\text { Open more } \\
\text { rescue, adoption, } \\
\text { or retirement }\end{array}$ & 3.22 & 0 & 17 & 14 & 3 & 3 & 37.0 \\
\hline $\begin{array}{l}\text { Reduce the cost } \\
\text { of euthanasia, } \\
\text { carcass disposal } \\
\text { Register all }\end{array}$ & 3.89 & 14 & 13 & 5 & 2 & 3 & 37.0 \\
\hline $\begin{array}{l}\text { horses with a } \\
\text { central agency }\end{array}$ & 2.30 & 3 & 3 & 8 & 11 & 12 & 37.0 \\
\hline $\begin{array}{l}\text { Regulate } \\
\text { breeders in the } \\
\text { state }\end{array}$ & 2.84 & 9 & 5 & 5 & 7 & 11 & 37.0 \\
\hline $\begin{array}{l}\text { Regulate horse } \\
\text { sales in the state }\end{array}$ & 2.35 & 4 & 5 & 6 & 7 & 15 & 37 \\
\hline
\end{tabular}




\section{APPENDIX F \\ HORSE OWNER QUALITATIVE RESPONSES STATING \\ PURPOSE OF THEIR HORSES}

\begin{tabular}{|l|}
\hline 23 years old lame \\
\hline 4-H horse activities \\
\hline Distance riding \\
\hline Enjoy my big furry aged friend mostly at home \\
\hline Enjoyment \\
\hline Equestrian Drill, camping \\
\hline Farming and pleasure \\
\hline Gaited dressage \\
\hline He's a pet \\
\hline Kane County Mounted Rangers \\
\hline None. Used to ride. \\
\hline Parades \\
\hline Pet \\
\hline Pointing Breed Field trials and Hunt Tests \\
\hline Pony Club \\
\hline Ranch work and roping \\
\hline Rare Breed Protection \\
\hline Retired \\
\hline Retired race horses \\
\hline Sale \\
\hline Some are retired to a life of leisure \\
\hline They pets that can be ridden, if desired \\
\hline Two are retired. \\
\hline Work cattle \\
\hline Yard ornament \\
\hline
\end{tabular}




\section{APPENDIX G \\ HORSE OWNER QUALITATIVE RESPONSES STATING OTHER \\ REASONS FOR SELLING THEIR HORSE}

After a 2nd marriage, my husband's gelding would chase my geldings if a mare was

present. We both sold our mares to regain barnyard peace.

Began a family.

Bought a different horse and can only afford one.

Bought a younger one.

Bought and sold horses trying to make money on them.

Bought him as a project horse, was not going to keep it.

Bought young- broke- sold.

Bought, trained, and sold many for timed events.

Bred him, raised and trained him sold him.

Breed, raise \& train to sell.

Breeding or showing prospect.

Breeding Stallion.

Breeding stock.

Breeding, showing, and selling is what we do.

Brood mares, Government messed with base prices with anti-slaughter.

Child outgrew pony

Claimed in a race

Claimed. 25000.00

College

Could no longer keep my horse with me because of moving.

Dangerous for young daughter to ride - sold to experienced rider.

Did not ride the horse.

Didn't fit well with the family or other horses.

Didn't have skill level or horse didn't work out for what I wanted to do in my riding

Didn't have time

Note. Continued on next page 


\begin{tabular}{|l|}
\hline Downsizing herd \\
\hline $\begin{array}{l}\text { Excellent match between prospect \& horse - was not planning on selling originally - } \\
\text { just worked out best for horse \& person. }\end{array}$ \\
\hline Family friend wanted to purchase \\
\hline Gave horse away as a breeding mare \\
\hline General horse business. \\
\hline $\begin{array}{l}\text { Have too many to give proper attention, training \& riding to each one on a daily basis. } \\
\text { This horse went to a one person - one horse family and will receive the best of } \\
\text { everything including individual daily attention, grooming, riding and being loved on. }\end{array}$ \\
\hline He was too spunky for me but was ideal for the younger purchaser. \\
\hline Health reasons \\
\hline Horse did not fit with our program- sold to a happy home \\
\hline Horse didn't fit with our riding style and wasn't being used \\
\hline Horse had heaves sold to young rider where heaves could be better controlled. \\
\hline Horse not suitable for our family \\
\hline Horse was a rock star \& his kid went away to college. \\
\hline Horse was dangerous \\
\hline Horse was not right for me. Traded for my current horse \\
\hline Horse was not suitable for trail riding \\
\hline Horse was too high spirited. I am older and was worried about getting hurt \\
\hline Horse was vicious \\
\hline Horses and my personality did not mesh. \\
\hline horse's skills did not match mine \\
\hline I became fearful of the horse \\
\hline I bought the horses with the intent to train and rehome them \\
\hline $\begin{array}{l}\text { I bring in horses that need help; help them; and find appropriate owners/riders for } \\
\text { them }\end{array}$ \\
\hline I had children and took time off from riding \\
\hline I had too many horses and needed to down size \\
\hline I raise and sell Missouri Fox trotters. We sell to make a profit \\
\hline I sold well trained horses to buyers who wanted them and paid for them. \\
\hline $\begin{array}{l}\text { I was a breeder who also bought and sold horses for endurance and } \\
\text { hunter/jumper/eventing }\end{array}$ \\
\hline I was breeding and sold some youngsters. \\
\hline I was youth beginner. Horse needed intermediate rider. \\
\hline In horse training business \\
\hline Incompatibility \\
\hline Last place to keep them, didn't have money to board out at the time. \\
\hline Note. Continued on next page \\
\hline
\end{tabular}


Limited space, wouldn't load, wanted a young horse to train for show, and sold my horse as a brood mare.

Mare for breeding

More appropriate for another discipline

Moved horse to good home that had the horse do a job. Soft caring people not abusive to horse

Moving

Multiple horses competing in the same division

Needed a new one

Needed to change to a better-tempered horse

New owner begged to buy the horse, would give it a good home, and I had too many.

Not enough attention, found better home

Not many places to race in the state of IL anymore and not able to compete

Offer too good to refuse

One was to a riding school because they needed him more than me. Other one was one

I trained and was safe for buyer.

Out grew horse skill level

Parents made me sell.

Pending divorce

Performance show horse

Purchased to resale after riding horse to make sure horse was safe

Raise and sell show horses.

Raised colts to sell

Raised or purchased with intentions of resale

Raised to sell, want to sell more

Returned to school, too busy to keep the horse in shape.

Sell colts

She went to a new home to teach children to ride.

Show horses - buy and sell for profit

Show or breeding prospect

Sold a show horse to a new younger owner to continue his show career

Sold as a brood mare.

Sold as a well-trained horse to a rider who had no horse.

Sold for breeding

Sold horse back to previous owner after some riding issues

Sold horse for other horse owners

Sold horses that we bred, raised and trained

Sold public trail riding string of horses, all well trained.

Sold so it could continue to be shown

Sold to fund purchase of other horse(s)

Note. Continued on next page 
Sold to make money. If the horse is unusable it is killed humanely.

Sold to show competitor

Someone I know wanted her

Suited better for the new owner/Too many horses

The horse was not appropriate for my needs

They were raised for the purpose of selling

To be shown or breeding potential $\$ 2000$ price of horse

To get better horse

Too many horses

Too many horses, less riders

Too much horse for me

Traded for another horse more appropriate to my level experience.

Trained it to be sold

Wanted a smaller horse

Wanted to move up to a higher level

Was a kid; had to choose between a horse or car

Was breeding and training to offset cost of hobby.

we breed, raise, and sell horses for a living

Weaning

Went to college/ married and did not have time.

What we raise them for

Young horse, bought with mother, kept mother, sold filly 
APPENDIX H

HORSE OWNER QUALITATIVE RESPONSES STATING OTHER REASONS FOR RELINQUISHING OR DONATING A HORSE.

\begin{tabular}{|l|}
\hline 4 H project \\
\hline A young girl \\
\hline Children's home for sale \\
\hline Donated a colt for a raffle \\
\hline Donated several horses to Salem4Youth \\
\hline Farrier/friend \\
\hline Gave a friend a horse when I moved back from Louisiana \\
\hline Gave away a horse due to a move \\
\hline Gave away to good homes two horses could not sell. \\
\hline Gave horse to a riding school \\
\hline Gave one to a 4H child \\
\hline Gave to a friend for her first horse. \\
\hline Gave to family \\
\hline Given away free \\
\hline Handicap riding \\
\hline Handicapped riding center \\
\hline $\begin{array}{l}\text { I am responsible for the horse. It is irresponsible to pass the care of an unusable horse } \\
\text { to someone else. }\end{array}$ \\
\hline I gave a horse away for free \\
\hline I gave a POA to a neighbor who used her as a mount for their special needs grandson. \\
\hline I have given away several horse to individuals since 2010 \\
\hline $\begin{array}{l}\text { I placed one with a family on a farm to be used lightly in his old age. To my } \\
\text { knowledge they passed him on to another family for their children. }\end{array}$ \\
\hline I rehomed my daughters pony to another family \& we still see him \\
\hline Lesson horse program \\
\hline Other person \\
\hline Returned to original owner for retirement \\
\hline Several times to children \\
\hline Therapy program \\
\hline $\begin{array}{l}\text { We let a therapeutic riding facility use a horse but maintained ownership and } \\
\text { responsibilities of care. }\end{array}$ \\
\hline
\end{tabular}




\section{APPENDIX I}

\section{HORSE OWNER QUALITATIVE RESPONSES STATING ORGANIZATION NAME}

\section{WHERE THEY RELINQUISHED OR DONATED THEIR HORSE}

\begin{tabular}{|l|}
\hline 4-H \\
\hline A riding school no longer in superstition, and Stone Ledge Farm \\
\hline ASAP in Wisconsin \\
\hline Cheff center \\
\hline Danada equestrian center \\
\hline Friends of Equine Therapeutic Activities \\
\hline Galloping out \\
\hline In Wisconsin, don't remember, sorry \\
\hline It was not an organization, just another family we gave him for free \\
\hline Kansas state university \\
\hline Midwest horse welfare foundation \\
\hline Missouri Foxtrotter Association \\
\hline NKT therapeutic riding \\
\hline Private barn \\
\hline Purdue university veterinary school \\
\hline Rainbow riders \\
\hline Salem children's home \\
\hline Salem ranch \\
\hline Salem4Youth \\
\hline SIU \\
\hline St. Jude's auction \\
\hline Starr therapy program \\
\hline Therapeutic riding New Kingdom trails riders \\
\hline Therapeutic riding, run by private individual \\
\hline U of I Vet School \\
\hline University of IL College of Veterinary Medicine \\
\hline University of Illinois Veterinary School, Sunshine Inc. Handicapped Riding Facility \\
\hline University of Wisc. Equine school \\
\hline Walking tall ranch \\
\hline William woods university \\
\hline Wounded Warriors \\
\hline
\end{tabular}




\section{APPENDIX $\mathbf{J}$}

\section{HORSE OWNER QUALITATIVE RESPONSES STATING OTHER RESPONSES OF}

\section{CURRENT METHODS TO CONTROL THE UNWANTED HORSE}

\section{POPULATION IN ILLINOIS.}

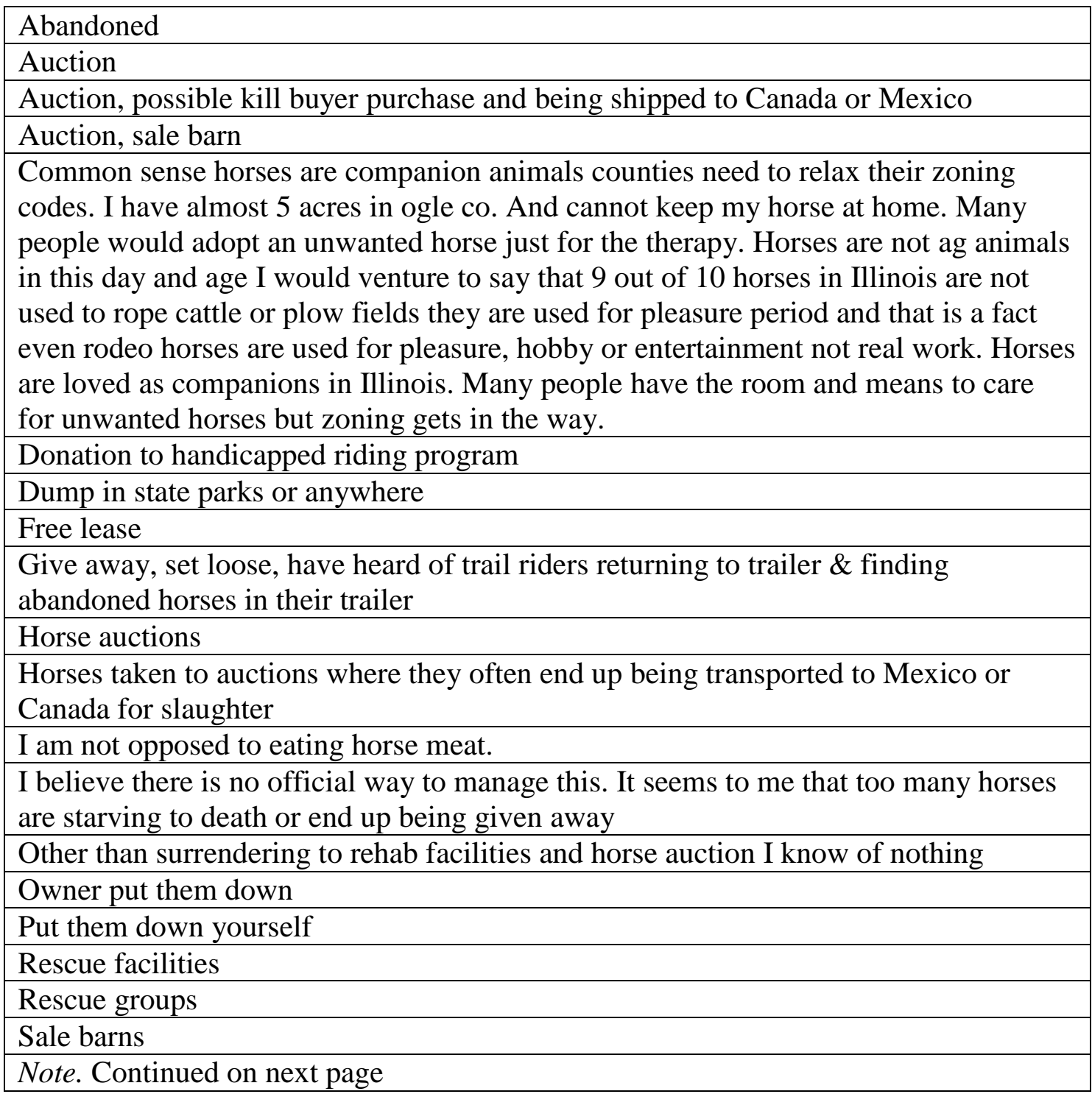


Sell at auction for transport to Mexico or Canada for slaughter

Send on truck 30 hours to slaughter in Mexico or Canada

Ship out of state or out of U.S.

Ship to Mexico for horsemeat

Shipped out of state to killer facility if eligible

Note Continued on next page.

Slaughter

Take to sale barn and hope someone else will take it home

Therapy programs

There are none

They don't have a method.

Turn them loose in state parks and reclaimed mine grounds

Very few avenues for old and unwanted horses and it's a shame to have to watch an old horse die. 


\section{APPENDIX K}

\section{HORSE OWNER QUALITATIVE RESPONSES STATING OTHER RESPONSES TO}

\section{WHO HAS THE PRIMARY RESPONSIBILITY TO MANAGING THE}

\section{UNWANTED HORSE POPULATION.}

\begin{tabular}{|l|}
\hline All of the above. They all play a part. \\
\hline Anyone who voted to close down kill plants \\
\hline Both owners and breeders \\
\hline Equal involvement by owners, breeders, associations, gov't \\
\hline $\begin{array}{l}\text { Guidance of Owners/breeders plus State Gov. for rules \& regulations of what can \& } \\
\text { can't be done. }\end{array}$ \\
\hline Horse are livestock should be regulated as such they are NOT lap dogs \\
\hline Horse breeders, including backyard breeders \\
\hline Horse owners and breeders \\
\hline Horse owners followed by laws of the state \\
\hline Horse owners if government laws would allow horse slaughter as an optional also \\
\hline Horses should be slaughter \\
\hline I believe it has to be a joint responsibility not just one group. \\
\hline Multiple answers apply, it is everyone's responsibility that partakes in equine activities. \\
\hline Not the local government or D of A \\
\hline Owners \& Breeders as well as Equine Associations to educate owners and breeders \\
\hline $\begin{array}{l}\text { Owners have the responsibility, Law enforcement must enforce and prosecute abuse } \\
\text { and cruelty }\end{array}$ \\
\hline Owners, breeders, organizations involved with horses \\
\hline Person who owns the unwanted horse \\
\hline Privately funded programs tax exempt \\
\hline $\begin{array}{l}\text { State and Federal Government that banned slaughter and horse breeders for over } \\
\text { production in declining market }\end{array}$ \\
\hline $\begin{array}{l}\text { Stop clumping horses into Agriculture they no more deserve to be there than cats or } \\
\text { dogs. }\end{array}$ \\
\hline $\begin{array}{l}\text { There was a good system in place until our government in all its wisdom listened to the } \\
\text { special interest groups. We need the slaughter houses and it would open up a whole } \\
\text { new process of getting rid of unwanted livestock. }\end{array}$ \\
\hline Whoever voted to close the processing plants. \\
\hline
\end{tabular}




\section{APPENDIX L \\ HORSE OWNER QUALITATIVE RESPONSES STATING WHERE THEY \\ ARE RECEIVING THEIR CURRENT INFORMATION \\ ON UNWANTED HORSES.}

\begin{tabular}{|l|}
\hline Word of mouth \\
\hline Breed rescue groups \\
\hline Craigslist \\
\hline Emails from Equine Rescue Groups \\
\hline Equine magazines \\
\hline Experience as an equine humane care investigator \\
\hline Farm Week and Equine Magazines \\
\hline Friend who is a rescue site for horses \\
\hline Friends \\
\hline Friends and neighbors \\
\hline Friends and other horse owners \\
\hline $\begin{array}{l}\text { From everyday life people are turning horses loose in our parks as they don't know } \\
\text { what to do with them so many are not being taken care of }\end{array}$ \\
\hline General news media \\
\hline Have seen horses dumped. \\
\hline HCI and I do my own research on computer searches \\
\hline Horse council \\
\hline Horse Council of Illinois \\
\hline Horse friends \\
\hline Horse owners \\
\hline Horseman's Council newsletters and emails \\
\hline Horseman's Council of Illinois \\
\hline I am a Regional VP and BOD member of a major horse breed. \\
\hline $\begin{array}{l}\text { I am registrar for a breed organization. I learn of unwanted horses from members on a } \\
\text { regular basis. }\end{array}$ \\
\hline $\begin{array}{l}\text { I only socially heard of horses being abandoned in other states. I don't know about } \\
\text { Illinois except Facebook posts }\end{array}$ \\
\hline I see posts in several horse groups about rescued horses from slaughter auction \\
\hline I volunteer at a vet clinic/ambulatory service \\
\hline Il horse council. \\
\hline Note. Continued on next page \\
\hline
\end{tabular}




\begin{tabular}{|l|}
\hline Internet \\
\hline Local riding/equine networks \\
\hline My ag related job also work at equine sale barn \\
\hline News, magazines \\
\hline News, Word of Mouth, Internet \\
\hline Newspapers and ads where PETA and HSUS misrepresent conditions. \\
\hline Other horse owners \\
\hline Personal experience \\
\hline Personal experience \\
\hline Personal Experience in dealing with folks that cant care for their horses \\
\hline Real-estate agent. \\
\hline Rescue organizations \\
\hline Self-directed research. \\
\hline Talking to other horse owners. \\
\hline Visual by driving through the country \\
\hline
\end{tabular}




\title{
APPENDIX M
}

\section{HORSE OWNER QUALITATIVE RESPONSES STATING SUGGESTIONS THEY}

\author{
HAVE FOR MANAGING THE UNWANTED HORSE POPULATION
}

\begin{abstract}
Create regional euthanasia centers-- great idea! Never heard of that before! A stallion registry is a good answer. Charging for each registered breeding could be source of revenue to help with education. But since the breeders have such a hold on the politicians, it will never happen. We survived before without a horse processing facility, we can survive now with out one now. Illinois horse association does NOT speak for all horse owners when they encourage the reopening of these facilities.
\end{abstract}

Adoption and retraining centers

Allow the horse processing facilities to re-open.

Allowing meat processing facilities to re open with humane transport of horses to the facility and humane killing of the animal for meat consumption, either for zoo animals or humans.

Although I do not think I could ever sell a horse for processing, I feel that this is probably the most efficient way to reduce the supply of unwanted horses. Much better that having people neglect horses because they cannot sell them.

As a horses owner for 50 years I have seen several horses that people no longer want. Unfortunately, in some cases the horses became old or injured and unable to be ridden. Some people feel if a horse does not have a viable use, they do not want them. Therefore, they want to get rid of them. The problem then arises on how to get rid of that horse, who wants it or doesn't want it. Some people will not euthanize their animal due to the money.

As a lifelong owner and breeder and lover of horses, I strongly support the re-opening of humane slaughter facilities. Throughout the world, horsemeat is regarded as a good source of protein. Though I would not want to do this myself, I rebel at the efforts of animal rights groups to dominate what I do with my horses. I am at a loss to understand why, if a farmer wanted to develop a fast growing, nutritious meat product based on equines, it would not be a violation of his rights to forbid such an enterprise. Assuming of course that all appropriate humane procedures were instituted.

Note. Continued on next page 
As a Quarter Horse owner, I've seen the value of Quarter horses drop dramatically with the closing of slaughter facilities. While I would never allow one of my own horses to end up in slaughter, I think it may be a necessary evil for those who are not responsible or financially stable enough for other options. As a Friesian owner, I see a lot of benefits to the way FHANA (Friesian Horse Association of North America) manages the breeding and registering of Friesians. Mares must be judged on conformation and movement in order to enter the studbook and stallions must pass rigorous testing of conformation, movement, disposition, under saddle, and driving to become approved breeding stallions. The Friesian horse has really not lost its value with the closing of slaughter houses, and one can only presume that this is because of the regulations FHANA has in place for horses to even be registered. While I don't think breed associations need to be quite as strict as FHANA, it might help to have something in place so that poor quality horses are not being bred.

As unpopular as the horse processing facilities are, I believe that they do serve a purpose. There are horses out there that are unmanageable and unwanted but do not deserve to live a miserable life in fear or neglect. Like with puppy mills, backyard breeders should be discouraged from indiscriminate breeding. As with dogs \& cats, a low cost gelding program would be attractive to owners.

\section{Better education of people}

Better education of the total costs involved and the time commitment prior to purchase of horse. Many people should not own horses, mainly because of finances.

Breeders need to take responsibility for the horses they produce. Owners need to be educated on options available. Low cost euthanasia and rendering services. I do not object to humane slaughter but I do object to the conditions in the kill pens and the transports.

Bring back horse processing facilities. Unwanted horses are no different than any other livestock animal when they are no longer useable; they turn into a commodity and people want a return on their money.

Bring back processing facilities, educate people on the aspects of owning a horse, improve euthanasia options

Bring back processing facilities, So the price of horses will go up, then not just anybody will be able to buy horse, and anyone that breeds more than one horse a year have breeder license.

Clamp down on the breeders -- with an iron fist!!! Why should they be allowed to bring more horses into the world when there are so many unwanted horses that deserve a good home? It is senseless. It's the same with dog \& cat breeders. Anything to make money at the animal's expense....and ultimately our expense!

Commercial slaughter establishes a base value for an unwanted horse and could decrease animal abandonment and neglect problems.

Note. Continued on next page 
Continue to promote the equine industry in our state and educate the next generations on the importance of a healthy equine population and care for horses. Work with local schools and municipalities to promote equine activities and support equine lifestyles and infrastructure necessary to co-exist in communities.

Control breeders. Too many backyard bred horses. Implement a strong gelding program, but I believe that should be done with a vet and an equine biomechanics specialist so only the healthiest, best conformed individuals are *licensed* to breed. Think mandatory inspections, similar to Europe, but mandatory. The other issue is people dumping their older/aged horses. If euthanasia was cheaper, maybe they would be humanely euthanized instead. I think culturally we need to accept putting down an animal for reasons other than health. I would rather see a neglect case put down by the owner, rather than suffering with poor nutrition because the owner has had to make the call of either can't afford euthanasia or feels judged for putting that animal down. The same goes for dogs and cats. Not a perfect solution.

Create a central horse adoption facility system where people can go to by or adopt horses from a neutral source, Like a horse CarMax

Create a educational program for people to learn about what goes into taking care of horses for example the expenses, veterinary care, feed, hoof care etc. prior into buying a horse or adopting

Don't like the thought of slaughter. But believe here in the U.S. We could regulate it to be done more humanely.

Educate citizens on the responsibilities of ownership. I keep a $\$ 5000.00$ to $\$ 10,000.00$ slush fund for vet emergencies and prefer a quiet euthanasia to any slaughter. Those who want to get rid of horses just because they are now too old are selfish and stupid!

Educate horse owners/buyers/backyard breeders about responsible breeding practices. People shouldn't be breeding their horses indiscriminately without a solid plan/purpose for the horse.

Educate people about horse ownership before they buy. Rising veterinary expenses are making it very difficult to keep the retirees. I have been blessed to be able to keep my retirees into their old age, so far.

Educate potential horse owners on the cost of ownership. Target back yard breeders, which is much like the puppy mill issue that is a current problem. Horses \& dogs/cats are life time commitment. Government control isn't the answer to managing unwanted horses. Look what it's doing with the BLM. Cattle ranchers are in the pockets of the government. If things were just left alone, natural selection would thin the herd.

Educating the people on the cost and what it takes to be a horse owner.

Education for new horse owners

Education HELLO???It is not breeders who over breed, it is backyard livestock owners who have no clue what to do with the horses that just happen to be bred. Require horse sales people to educate buyers prior to purchase... On cost of care, and eventual cost of disposing. Fines for owners of horses sold to killers... No killers allowed at auctions, and gelding that is cheap...like the dog/cat rescues do. Disallow ignorant people from becoming rescues who cannot pay for the care themselves.

Note. Continued on next page 
Education of owners and breeders as to the cost and responsibility of horse ownership by Breed organizations, 4H, FFA, Equine magazines, etc.

Education on what types of horse should be euthanized or sent to processing facilities. Processing facilities should be Humane and government regulated.

Education thru social media and strongly support the reopening the processing facilities! Education, perhaps annual fees similar to rabies tags, etc., for canine population. It would help to know the demographics of the people who are not caring for their horses. That would help us think about how to reach that group. I would also guess that population is not accessing this survey. I appreciate your investigation of this topic.

EDUCATION: Educate people how much $\$ \$$ costs to maintain a horse; time it takes to just maintain a horse. $80 \%$ do not realize what is involved; leave a horse to fend for itself without proper care resulting in neglect. STRICT ENFORCED LAWS for neglecting; mistreating horses punishment $\$ 1000.00$ 1st offense minimum \& $180 \mathrm{hrs} . / 30$ days ( $3 \mathrm{hrs}$. each day, 2 consecutive days each weekend totaling 30 days)of documented cleaning manure at a large rescue horse facility. If none available find a local horse facility \& put these people there to work off time.... THEN maybe they will THINK the next time rather than just neglect or dump them off on someone. ENFORCE LAWS ON THE BOOKS AND MAKE THEM STICK.

Education. If people know what they're getting into, know how to manage a horse, know where to take lessons, who their local vet is, what basic horse care is required, are aware of competition venues and horse trails I think it would go a long ways towards helping the population. I have no idea how that education gets to the average person before they take a leap and purchase their first hose it would make a big difference. I think more education would result in less backyard breeding, and better horse welfare overall, then in turn less unwanted horses. That may just be me and my rose colored glasses speaking though :-)

Encourage humane meat processing facilities for human consumption and/or facilitate organizing procedure to donate horses for zoo animal consumption.

Encourage people to ONLY breed quality animals and reduce the number of backyard breeders.

Encourage veterinarians to distribute fact sheets on horse ownership

Establish turn in facilities where people who cannot afford to keep or euthanize their sick/unwanted horses could take them and surrender/donate them without fear of reprisal. Coordinate with rescue orgs, university programs, veterans programs and programs such as Last Chance Ranch the prison in Vandalia to take adoptable horses. Humanely euthanize those that cannot be helped. If you have a horse that has become un-rideable, or dangerous to handle but is otherwise healthy - it is a moral dilemma as to what you could/should do. Most folk can't afford to keep a horse that they can't ride - as it means they can't afford to buy a horse they can ride. I think that sadly there is a place for euthanizing those horses. It would help if it was low-cost and at no profit for the owner.

Note. Continued on next page 
Euthanasia is currently socially unacceptable unless the horse is unhealthy, has a poor quality of life, seriously injured, or dangerous. It would have to become more acceptable to euthanize a healthy horse because the owner can no longer keep it or find it another home, for whatever reason, in order for that to be a truly viable option.

Expect people to be responsible and reasonable in what they do...which, sadly, is not likely to happen. It hasn't worked in small animals, and is not likely to work with horses either.

Export and slaughter

Fee to breeders and tax on all sales go into a fund to provide humane euthanasia for horses when they are unwanted and re homing fails

Fining those individuals who no longer provide for the horses they own.

For whatever reason there are always going to be unwanted horses. We need to make it more cost effective to surrender or euthanize these animals. This process also needs to be monitored by a state agency.

Get processing facilities back into operation!

Get the government and do-gooder human societies out of the decision process and let the horse owner decide; keep the horse, sell the horse to another horseman, sell the horse for slaughter (human or animal consumption) or euthanasia. Have all options on the table, except cruel treatment.

Getting more information to horse owners and potential horse owners about the costs of horse owning and options available to the owner when horse is elderly, unable to perform tasks owners need and/or there's a substantial change in the owner's ability to care for the horse(s).

Have horses go into holding areas put up for adoption to right people. Horses that are not good horses (too old, medical problems, etc.)Euthanasia.

Hold owners accountable.

Horse processing plants for those animals that are verified 'unsalvageable' due to serious injury or unmanageable.

Horse slaughter

Horse slaughter is not the answer to this problem. Horses are not raised in the US as food animals and that opens a whole different can of worms that most horse owners do not want to deal with. Responsible ownership and breeding is important. People think they will make tons of money breeding and selling horses. This is a bad business plan. Sadly there are a lot of unintelligent people in the horse world. Requiring breeders to be registered would help. Also giving people access to affordable euthanasia would probably be the best answer to the problem.

Horse slaughtering plants are good for the economy. Provides humane way for people to get rid of unwanted horses. This is good for horse and feed market.

Host fund raisers to buy a huge farm where horses can live out the rest of their natural lives.

Humane transport and slaughter. Industry supported euthanasia centers. Note. Continued on next page 
I am against any sort of registration of horses. I think there should be reasonable euthanasia costs, public education about options of what to do with unwanted horses, reopening of processing facility in Illinois with very strict and highly enforced humane rules. Owners or abused horses should be severely prosecuted. Owners of neglected horses should be worked with to be educated on taking care of horses and provided assistance but horses should be removed sooner when there is no immediate improvement. These situations should be more closely and frequently monitored to ensure the continued welfare of the horse.

I believe open up processing facilities, but also owners and breeders MUST be held accountable for bad breeding practices. Shows and judges also need to assume some responsibility also. Too many people are trying to get the PERFECT horse and keep breeding until they do!!

I believe that education for horse owners and responsible breeding will benefit the unwanted horses. I believe that if horse care such as hay, grain, vet care etc., was not so outrageous then folks could afford to care for their horses. I believe that like the cat and dog population folks should not breed just because they happen to have a stallion and a mare. Education is the key, as well as gelding the stallions

I believe that processing is effective at least the meat isn't going to waste and can go towards a cause to help feed those in need. And the cost is a lot cheaper for the government then more rules and regulations that will just take more of our rights away

I can only say I am against horse processing plants. I've seen the trucks, the horrifying videos and I just can't agree with it.

I don't think the average horse owner is aware of the problem. I think there are many IL horse owners who would donate to and/or adopt unwanted horses if they were made aware of available/needy horses.

I know that many camp horses are auctioned off at the end of the season. There should be some kind of regulation so that these horses are cared for rather than being disposed of. My first horse was an unwanted camp horse. He became a favorite lesson horse where I boarded because he was so sweet with kids. But if I had not bought him, he would have gone to the killers. He lived to be over 30 before having to be put down due to poor health.

I really don't know what the answer is. If it was up to me I would hold each horse owner responsible. I am a animal lover and feel if you take in a animal, be it dog, cat, horse etc. That it is your responsibility to make sure it is cared for. If you cannot find it a good home then do the right and euthanize the animal. After all, they can't make those decisions for themselves. Financially, the processing facilities helped the people who could not afford the euthanasia fees but the animals should be humanely treated up to that point. There should be laws in effect to allow that.

I think regional rescue adoption centers would help, but perhaps incentives to trainers to take the horses and retrain/sell them. Laws need to change to be much more severe for abuse/neglect to hold owners accountable.

Note. Continued on next page 
I think that breeders (backyard or pros) need to cut back on how many foals are produced each year. Some people believe they have to keep breeding even though demand is down. I also think there should be classes to help new owners understand the cost of owning a horse.

I think that we need to reopen horse processing facilities in Illinois I know it is not the best thing as some of the horses are not treated right at these plants but it cannot be any worse than taking months to starve a horse so that it is just skin and bones I have been where there were several horses already dead and more that would die as they were so poor we take these 20 to 30 year old horses feed them up and then try to find places to place them as pasture buddies who can afford to do this it is expensive if you take care of the horse feed shoeing vet fees I guess I am older the money spent on these horses could go to feed the homeless people help with children that have no home why can't these horses just be put down before they brought back to life to me it would be the humane thing to do some organization wanted 9000.00 to fix the leg on a yearling filly that was going to have to have surgery and the filly was never going to be able to be rode after the surgery what is the point the organization got the money it needed and the filly's leg was fixed so she could play in the pasture I gave money to an organization once and then found out by mistake that the money went to New Zealand so it did not even stay in the USA

I think you have to have the horse processing facilities as a means to dispose of animals in a humane way rather than leave them to starve or be mistreated.

I wish I had the answer to that. No one answer seems to be the final word on managing the unwanted horses. Responsible ownership is very important. When it comes to retires racehorses, once they are done racing, owners don't seem to care what happens to them. At this point while I totally dislike euthanizing them, it may be the most humane thing to do.

I would have checked horse-processing facilities except that horses which have drugs in their systems (which are most of them) cannot be sold for human consumption--so this choice is not a practical one. Current slaughter facilities outside of the US often don't care about this detail, which I think is a travesty.

I would like to see the horse processing facilities be reopened. It was humane, cost effective and convenient. Too much money is wasted on horses that are too old, disabled, un-trainable or no longer useful to keep them alive. They should be euthanized or processed for food. The current expense of euthanasia and disposal is prohibitive for many horse owners to have done.

I would rather see horses be put down and processed through slaughter facilities, than to see them starved and neglected.

Note. Continued on next page 
I would require breeders of horses to have a license of some type, perhaps issued by the state with an exemption for breeders who obtain a license through a registry that has a similar program (I don't think any do yet). Horses are more typically companion and recreational animals than they are working animals, and as such, they take more resources to care for than smaller animals, such as cats and dogs, if their owners relinquish them. Therefore, I think the state is justified in requiring a license for breeders. A potential problem, however, is that breeders might take their business to other states, in which case, breeders incentives for quality horses could also be an option to keep breeders in state and producing good animals instead of breeding any two horses they might have available. They should strive for quality over quantity.

I'm against regulation by the state. It would work, but would drive up the cost of buying a grade animal, yet doesn't address the knowledge of the buyer for the care of the animal. I've seen what regulation did for the dog and cat population in the state of MA. Couldn't find a free puppy or kitten. Had to buy a purebred. Two out of my three horses were given to me. They are Arabians, my horse of choice. They were unwanted by their past owners. They are wonderful animals that I trail ride. I like all the options that I have checked as 'effective.'

If anyone buys a horse they should take care of it. If they can't sell or give it away when they no longer want it they should kill it. If they abandon the horse and they are found out they should be subject to a civil forfeiture administered by the States Attorney in the county for the amount to recover the horse, maintain it if that is desired, euthanize it humanely, and there should be a minimum penalty that secures attention. There should be an educational program that teaches people who have lost touch with how to maintain livestock on how the animals should be maintained. They must understand that if a horse can't be maintained they are responsible for putting it down. They must understand that it would be better to save the protein by slaughter than wasting it. They must understand life is not a Walt Disney movie. I am getting tired of people abandoning cats and dogs outside my barn on my farm. I am getting tire of PETA and HSUS grifting people out of their money to pay huge salaries and pervert nature. I am getting tired of people not understanding the huge responsibility of keeping a horse and the consequences of not properly maintaining them. They are not motorcycles you can park in the garage. For crying out loud I just wonder if your survey can have any effect on the societal irresponsibility that makes the issue of unwanted horses a problem. Maybe you should have a survey on what we do with unwanted people. I will participate in that survey.

If caught, fine owners severely for turning out horses in state parks like Shawnee. Have a place for people to bring their unwanted horses, even if they have to pay to get rid of them. Some horses are too spirited for owners who run out to buy a horse because they had one trail ride and became an expert equestrian during that one hour ride and then reality sets in. Some people just can't afford them any longer due to financial hardships and just turn them out in parks. People need to become responsible for their actions.

Note. Continued on next page 
Implement fees and stronger regulations for breeders regardless of whether professional or backyard, and make breeders responsible for the horses they bring into the world for life (return of the horse to the breeder if it doesn't work out for the buyer). Implement a fee on all sales of horses nationwide to help fund rescues. Pass legislation making the transport of horses out of the country for slaughter illegal with a large fine and mandatory jail time if caught. Make a portion of all show fees used to fund rescues. Implement a portion of all breed registries fees to be used to fund rescues. Toughen abuse laws with mandatory large fines and jail time, as well as prohibiting animal ownership. Develop horse food and supplies pantries for owners who fall into financial difficulties but don't want to give up their horses.

Improve the overall economic conditions. Reduce explosive property taxation that is forcing horse owners (and non-livestock property owners alike) to move and dispose of horses and other livestock. Quit rezoning agricultural land into estate and driving out the horse owners in lieu of ineffective, needless development. Encourage rather than discourage Voc-Ag education.

It is largely the race horse industry who cause the overpopulation

It is not up to the state to tell a person how many they can have But I do believe when the Processing plants were open we didn't have this problem It cost way too much to disposal. Find those that just turn them loose in parks IF you can find them!

Keep PETA out of this. We did not have this problem when there were rendering plants. Now unwanted horses are sent to China for meat and they are sent to Mexico and Canada with a very cruel ride to their destinations. We don't need the government involved either.

Keep politics and animal activist out of it Open the equine harvesting facilities back up Gov't should not be telling people what they can and cannot eat. The industry collapsed when do-gooders got involved

Larger fines \& jail time for abuse \& neglect. Incentives for gelding horses

Legalize horse-processing plants with humane management for the end-of-life process. People who cannot afford to have aged/injured horses euthanized need to have an option. Some horses are not safe and never will be safe, and are sold because owners have no other recourse.

Limit all breeding.

Make it easier for boarding facilities to take control of boarder's animals when not being paid... And to take legal action against negligent owners. Enforce animal neglect laws... Make it less expensive to have your humanly euthanized and disposed of I used to be an Investigator with HAHS and unwanted old and lame horses are hard to re home Make potential owners aware of the cost of owning and maintaining a horse for a year. Also make them aware of the work involved on a daily basis. An interesting idea might be horse co-ops were in individuals could help one another on a regular basis Mixed feelings about slaughter, thought it can spare horses limitless misery such as hunger and illness. Hate the idea of horses being shipped hundreds of thousands of miles to slaughterhouses. Rather have their trauma limited to a shorter period.

Note. Continued on next page 
More education about horse ownership for people who did not grow up with horses and who might think is just 'cool' to own a horse. Reopening processing plants for horse meat, then put into dog food $€_{\mid}^{\mid}$which is what USED to be in dog food for a LONG time prior to the time of closing horse processing plants!!!!

More programs for prisoners and youth to care for unwanted horses and rehab them thru learning skills like ground work, natural hoof balance trimming etc.. To make horses more sound and calm/trained/desirable for the horse adoption or sale market.

More public awareness of the problem would help

More readily available education programs for prospective new owners. Develop agencies to act as intermediaries to match prospective owners with unwanted horses.

Much greater punishment and accountability via new laws for horse owners that are found guilty of abuse and neglect. Jail sentencing or very costly fines etc.

Open back up slaughtering of horses.

Open back up the kill plants.

Open humane horse processing facilities for old, badly injured, dangerous horses. This would help. Horse owners must take responsibility for horses that they buy.

Open our processing facilities so horses will not suffer due to lack of money and knowledge.

Open processing plants to drive down the number of horses, which will bring the market back.

Open slaughter plants

Open slaughterhouses

Open the processing facilities and let the free market work to dispose of unwanted animals to the highest bidder.

Owner/breeder responsibility

Owning a horse is expensive. Raising the cost to obtain a horse will decrease the number of people who get them just to have one without understanding the expense of care. Lots of unwanted horses are from poor breeding practices and from the racing industry. Cut 3 yr. old purses and put money on 6 to 10 year old racers will make it unprofitable to breed disposable racehorses. Killing the horses should never be an acceptable solution for horses that are still capable of a good quality of life.

Please re-open the slaughterhouses!!!!!!! They are honestly the only best way to dispose of the excess without huge costs to taxpayers who shouldn't have to pay for horse people's lack of finances or responsibility for breeding decisions. They were a way for desperate people without the means to keep their horses any longer. They also don't create a huge disposal problem like euthanasia centers do. I love my horses, but I've owned them for over 40 years and have become a realist about the situation, no longer a bleeding heart not in touch with reality.

Pray for owner responsibility

Pressure on quarter horse and thoroughbred breeders to place unwanted horses

Note. Continued on next page 
Provide better definition for Adoption; use set aside techniques to raise funds to support rescue/adoption/retirement facilities.

Quit listening to PETA and Humane Society crap and start the slaughter plants again.

It's a humane way to get rid of the bottom end of the horse population and will help with prices in the long run. The cost of a vet and disposal is outrageous and cannot be justified for those in the business.

Re-open horse processing facilities

Re-open the processing plants.

Reducing the cost of disposal would help a lot. Also if horse processing facilities stay closed the regional euthanasia centers should be available.

Register all horses at time of birth or purchase for a small fee. Plus, require first time owners to take a one hour horse keeping orientation class in order to acquire permission to own a horse. This class would instruct newbies in what it takes to keep horses. It would help eliminate the folks that think it would be fun to own a horse....and maybe protect horses from being stuck in lonely stalls in boarding facilities (horse prisons).

Regulate breeders

Regulate the breeding of horses for racing

Reopen humane slaughter in US so horses are not sent to Mexico.

Reopen processing centers in Illinois

Reopen slaughterhouses.

Reopen the local facilities so unwanted horses aren't being hauled many miles across boarders and the rendering process can be managed and monitored locally. Closing the facilities did nothing to help the horse, but instead caused undue trailing time for the same fate. Their value plummeted due to low end horses no longer being worth anything. I attend the local auctions regularly and people cannot give away some horses who are dangerous or unable to be used, even those that are completely healthy

Reopen the processing facilities. Give the old, injured, dangerous horses a place to be humanly euthanized

Reopen the slaughter facilities and stop listening to the animal rights groups. Make the animal rights groups pay to maintain or euthanize all of the unwanted horses they have caused.

Reopen the slaughter houses

Reopen the slaughter houses The slaughter bill can be changed

Reopening horse processing facilities will establish a bottom line value for all horses and stimulate the development of the other options mentioned.

Note. Continued on next page 
Repeal anti-slaughter legislation to allow slaughter facilities to process unwanted, lame, blind, dangerous horses for domestic animal feed protein or export.. Over 90,000 head per year were processed for meat and had a per pound value, that was the basis for starting auction bids on live horses... Now some horses receive no bids, others are bought for slaughter transport to Mexico and Canada... Very inhumane in Mexico, very long transport stress on horses, exporting jobs and horse value to foreign countries. I like the idea of regional euthanasia facilities...they could be free to the owner... The cost of transport...and supported by purchase of carcasses by rendering plants for by products. This could be competitively bid. I oppose the idea of the federal or state government interfering in the normal market dynamics of supply and demand. Absent government interventions... I.e. slaughter bans, or imposed controls of populations, the horse market would cycle correct and demand for horses would stabilize...this would result in more horse related commerce. And employment

Since I think processing meat factories are way to cruel, but then so is going in a trailer to Canada \& Mexico are even crueler. The horse suffers going to those places, plus they are not regulated very well. Maybe having a euthanasia center. Would be better. I'm just not real sure. It is a big problem.

Slaughter is not the answer. These animals are not raised as like other animals intended for slaughter, human consumption or not. Horse owners need to cowboy up and make the tough call not just ship their old and injured horses to auction think someone else will care for them. Transportation for horses bound for slaughter is still horrendous and horses in other parts of the country are still stolen and sold to slaughter houses with nothing at their end. Vet and Rendering is crazy costly and there seems to be less of them in my part of Illinois they come from Iowa. There is no good answer but the answers starts with the owners.

Slaughter they are livestock not pets

Slow the breeders down Educate potential horse owners

So many horses are bred for professional use and if they don't perform they are in some way disposed of. I bought a great horse, as a trail horse, but he was bred to be a barrel racer. He could not perform, so they just left him in the pasture until I saw him one day and bought him. Crack down on people who indiscriminate breeding to lesson unwanted horses. People are greedy. How do you control that? Hard times, how do you control that?

Somehow make it easier to find resources for a horse owner to humanely euthanize a horse if it is old, unmanageable or otherwise unsuitable to riding....and...Provide resources so an owner can easily place a good horse into a facility or training program if the horse is still able to be trained or used for pleasure riding or as a companion. I am not in favor of any government regulation on anything...should be the owners and the associations....maybe the state....definitely not the federal government!

Stop the back yard breeders. I know several that can't take care of their horses properly but they breed to have babies. They also don't care about whether horses should be bred or not. Some horses should never be bred because of temperament or defects but they are..............

Note. Continued on next page 
Stopping uneducated people from indiscriminately breeding horses would bring about the most change. Unfortunately this sounds great in theory, but would be very difficult to put into practice. Another effective method would be to make euthanasia and body disposal less difficult and cost prohibitive. And although I do not agree with the slaughter of horses mainly due to the inhumane methods of killing and transport, this was and always will be an effective method of management of the unwanted/crippled/abused/neglected/sick. I just don't believe it should be the primary method and some definite changes should be implemented in the slaughter industry. Slaughter is ugly. Starvation is uglier.

Strongly agree with horse processing facilities!!

The major effort should be in education about proper horse care by organizations like 4 $\mathrm{H}$, FFA, and breed organizations. We don't need more government regulations. We need to properly enforce the ones we already have.

The sale barns are still open. If the horse is still usable- as a riding/driving animal then there are plenty of ways to place a horse if the owner is willing to do a little leg work. The horses that are unwanted and unpeaceable are the pets untrained \& unmanageable with no useful skills. These animals wind up either being neglected or at sale barn headed to Mexico

There are no easy solutions. Breeders, especially of racing horses, will always continue to produce more foals than necessary with the hope that one or more will be a big winner, but unfortunately those that aren't are disposable, as well as the unwanted foals who are produced from nursemaid mares. For other people who just think it would be fun to own a horse but have no knowledge of the cost of keeping a horse, it would be great if there was some way they could be educated about that, but that isn't a feasible solution. If rescues could receive some kind of funding other than charitable contributions, that would help. And it is a reality that the horse market has tanked because horse processing plants have closed across the country, making it very difficult for owners to get rid of unwanted horses. I'm not a huge fan of such facilities, but properly managed where the animals - equines and other meat animals - are treated humanely are a better solution than letting horses starve to death.

University research programs; University schooling programs, etc.

Unreasonable regulations with zoning are a big problem. I don't think regulations are an answer however if you did register all horses you would surely find out that what I am telling you is true. Horses are companion animals. Illinois recently passed a law stating that miniature horses are companion animals why not full size horses the only real work that horses are doing in Illinois is through Therapy for Veterans, Disabled and Special needs adults and Children. It boils down to common sense make the counties relax their zoning laws to state that if a person owns property the 1 horse 1 acre rule would apply provided that proper housing and fencing are intact.

Note. Continued on next page 
Use to be able to go to a horse auction at least once a month and not have to drive 150 miles. The horse buyers would give a little something for an old or crippled horse and make a little by taking it to slaughter house. It is obvious what needs to be done but the animal huggers have too much money and time on their hands. Horses are special and to watch an old friend wither to nothing is not humane. Bring back the slaughter houses and issue would go away. And if you don't want your horse to go that way just keep feeding it and pay the vet to kill it cause one way or another life must end for every living creature.

Way too easy to breed horses and mules. It is my opinion that we should explore (tax stallions. Any stallion/stud/jack of breeding age should be registered with the state and subject to a tax. We need to reduce the number of stallions asap

We must educate the people to become exemplary stewards of this Earth as our ancestors were. There is nothing correct about killing in any way shape or form. That includes killing to eat meat of any sort. It must start with the people. In the interim, kindness (prolife) facilities should be created to care for and manage a network of foster homes. Breeders should be held accountable for all life they bring forth for the life of the animal.

We need to get the slaughter plant reopened. Not just in Illinois, but elsewhere in the country. I believe that it all has to do with having a decent floor price to value the horses in the market place. They are seen as a protein source on the world market. So there should be a base that is comparable to the beef price. I can go to an auction and buy a yearling horse for about $\$ 150$ that same aged calf, and weigh about the same will be well over $\$ 1000$. In our area there are too many people that can afford to buy a horse but not even consider the actual cost of ownership. In turn you can drive around the countryside and see to many thin, unkempt horses.

We should try to have the least government involvement. The state of IL is already financially strapped. I love horses. There is no way to relieve a person of a horse other than to sell it or give it away and some people just don't want to go to the trouble/time involved for an ad. In some instances, the horse is not able to be sold/donated because of age, injury or requires training. We need processing facilities. Regional/contract euthanasia centers was something I hadn't thought of which would be helpful.

Well, as I answered these, the droughts in Texas and California are on my mind. A little of this is a climate change thing. When I think unwanted WILD horses, I don't think Illinois, I think out west. There are some careless owners. One of my friends bred a mare a second time because she did not like the color on the first baby. Oh brother. Don't do that when there are already too many horses. People need to remember that a horse lives much longer than a dog, so breeding a horse is SERIOUS. You will have this baby for 25-40 years.

When the processing facilities were open prices of good horses was up, thus making it more profitable to sell a broke horse or a good young horse so people could afford to take care of the horses they kept. Breeders who just breed for the fun of it and don't care about registering or doing the proper thing with their foals don't care about in education and sometimes no matter how you talk to them they are not interested in learning or caring.

Note. Continued on next page 
Why do we have an unwanted population? If we knew that then maybe we could head off the problem of unwanted horses. Education, Education, Education. A horse is not like a car or a bicycle, it is a living thing, you buy it, and you care for it for life. A 20 to 30 year commitment! 


\section{APPENDIX N \\ DEFINITION OF TERMS}

Equine refers to horses or ponies, or pertaining to those in within the equine family. An equine belongs to the family equidae that includes ponies, donkeys, mules, horses, zebras, and asses (Oxford dictionaries, 2015.)

Equine Industry Stakeholder refers to any individual whose primary income comes from an occupation that directly involves an aspect of the equine industry. Equine industry stakeholders positions include: auction or sale barn operator or staff, barn staff or manager, horse breeder, boarding or training facility staff, manager, or operator, equine veterinarian or vet assistant, equine breed association staff, equine media editor or staff, farrier, feed store staff, manager, or owner, horse trainer, race track (operator, staff, barn worker, hot walker, stall cleaner, jockey, groom, exerciser), rescue, adoption, or retirement facility staff, manager, or owner, riding instructor, state agricultural or veterinary official.

Horse Owners are classified as individuals currently living in Illinois and currently own at least one horse.

Non-Horse Owners are individuals that are currently living in Illinois and who do not currently own a horse. 